\title{
Effects of nitrogen deposition and empirical nitrogen critical loads for ecoregions of the United States
}

\author{
Linda H. Pardo, ${ }^{1,20}$ Mark E. Fenn, ${ }^{2}$ Christine L. Goodale, ${ }^{3}$ Linda H. Geiser, ${ }^{4}$ Charles T. Driscoll, ${ }^{5}$ \\ Edith B. Allen, ${ }^{6}$ Jill S. Baron, ${ }^{7}$ Roland Bobbink, ${ }^{8}$ William D. Bowman, ${ }^{9}$ Christopher M. Clark, ${ }^{10}$ \\ Bridget Emmett, ${ }^{11}$ Frank S. Gilliam, ${ }^{12}$ Tara L. Greaver, ${ }^{13}$ Sharon J. Hall, ${ }^{14}$ Erik A. Lilleskov, ${ }^{15}$ \\ Lingli Liu, ${ }^{13}$ Jason A. Lynch, ${ }^{10}$ Knute J. Nadelhoffer, ${ }^{16}$ Steven S. Perakis, ${ }^{17}$ Molly J. Robin-Abbott, ${ }^{1}$ \\ John L. Stoddard, ${ }^{18}$ Kathleen C. Weathers, ${ }^{19}$ and Robin L. Dennis ${ }^{13}$ \\ ${ }^{1}$ USDA Forest Service, Northern Research Station, 705 Spear Street, South Burlington, Vermont 05403 USA \\ ${ }^{2}$ USDA Forest Service, Riverside, California 92507 USA \\ ${ }^{3}$ Cornell University, Ithaca, New York 14853 USA \\ ${ }^{4}$ USD A Forest Service, Corvallis, Oregon 97339 USA \\ ${ }^{5}$ Syracuse University, Syracuse, New York 13244 USA \\ ${ }^{6}$ University of California, Riverside, California 92521 USA \\ ${ }^{7}$ U.S. Geological Survey, Fort Collins, Colorado 80523 USA \\ ${ }^{8} B$-WARE Research Center, 6525 ED Nijmegen, The Netherlands \\ ${ }^{9}$ University of Colorado, Boulder, Colorado 80309 USA \\ ${ }^{10}$ U.S. EPA, Washington, D.C. 20460 USA \\ ${ }^{11}$ Centre for Ecology and Hydrology, Bangor, LL57 2UW United Kingdom \\ ${ }^{12}$ Marshall University, Huntington, West Virginia 25755 USA \\ ${ }^{13}$ U.S. EPA, Research Triangle Park, North Carolina 27711 USA \\ ${ }^{14}$ Arizona State University, Tempe, Arizona 85287 USA \\ ${ }^{15}$ USDA Forest Service, Houghton, Michigan 49931 USA \\ ${ }^{16}$ University of Michigan, Ann Arbor, Michigan 48109 USA \\ ${ }^{17}$ U.S. Geological Survey, Corvallis, Oregon 97331 USA \\ ${ }^{18}$ U.S. EPA, Corvallis, Oregon 97333 USA \\ ${ }^{19}$ Cary Institute of Ecosystem Studies, Millbrook, New York 12545 USA
}

Abstract. Human activity in the last century has led to a significant increase in nitrogen (N) emissions and atmospheric deposition. This $\mathrm{N}$ deposition has reached a level that has caused or is likely to cause alterations to the structure and function of many ecosystems across the United States. One approach for quantifying the deposition of pollution that would be harmful to ecosystems is the determination of critical loads. A critical load is defined as the input of a pollutant below which no detrimental ecological effects occur over the long-term according to present knowledge.

The objectives of this project were to synthesize current research relating atmospheric $\mathrm{N}$ deposition to effects on terrestrial and freshwater ecosystems in the United States, and to estimate associated empirical N critical loads. The receptors considered included freshwater diatoms, mycorrhizal fungi, lichens, bryophytes, herbaceous plants, shrubs, and trees. Ecosystem impacts included: (1) biogeochemical responses and (2) individual species, population, and community responses. Biogeochemical responses included increased $\mathrm{N}$ mineralization and nitrification (and $\mathrm{N}$ availability for plant and microbial uptake), increased gaseous $\mathrm{N}$ losses (ammonia volatilization, nitric and nitrous oxide from nitrification and denitrification), and increased $\mathrm{N}$ leaching. Individual species, population, and community responses included increased tissue N, physiological and nutrient imbalances, increased growth, altered root: shoot ratios, increased susceptibility to secondary stresses, altered fire regime, shifts in competitive interactions and community composition, changes in species richness and other measures of biodiversity, and increases in invasive species.

The range of critical loads for nutrient $\mathrm{N}$ reported for U.S. ecoregions, inland surface waters, and freshwater wetlands is $1-39 \mathrm{~kg} \mathrm{~N} \cdot \mathrm{ha}^{-1} \cdot \mathrm{yr}^{-1}$, spanning the range of $\mathrm{N}$ deposition observed over most of the country. The empirical critical loads for $\mathrm{N}$ tend to increase in the following sequence for different life forms: diatoms, lichens and bryophytes, mycorrhizal fungi, herbaceous plants and shrubs, and trees.

The critical load approach is an ecosystem assessment tool with great potential to simplify complex scientific information and communicate effectively with the policy community and the public. This synthesis represents the first comprehensive assessment of empirical critical loads of $\mathrm{N}$ for major ecoregions across the United States.

Key words: air pollution; atmospheric $N$ deposition; biodiversity; community shifts; natural resource protection; nitrate leaching; nitrogen saturation; plant nitrogen cycling; vegetation type conversion.

Manuscript received 10 December 2010; revised 30 March 2011; accepted 1 April 2011; final version received 24 May 2011. Corresponding Editor: D. R. Zak.

${ }^{20}$ E-mail: lpardo@fs.fed.us 


\section{INTRODUCTION}

\section{Effects of nitrogen deposition on ecosystems}

Human activity in the last century has led to a significant increase in nitrogen $(\mathrm{N})$ emissions and deposition (Galloway et al. 2004). Because of past, and, in some regions, continuing increases in emissions (Nilles and Conley 2001, Lehmann et al. 2005), N deposition has reached a level that has caused or is likely to cause alterations in many ecosystems across the United States. In some ecoregions, the impact of $\mathrm{N}$ deposition has been severe, altering $\mathrm{N}$ cycling and biodiversity. Indicators of altered $\mathrm{N}$ cycling include increased $\mathrm{N}$ mineralization, nitrification, and nitrate $\left(\mathrm{NO}_{3}{ }^{-}\right)$leaching rates, as well as elevated plant tissue $\mathrm{N}$ concentration. The eventual outcome of increases in these processes can be $\mathrm{N}$ saturation, the series of ecosystem changes that occur as available $\mathrm{N}$ exceeds plant and microbial demand (Aber et al. 1989, 1998).

As $\mathrm{N}$ availability increases there are progressive changes in biotic community structure and composition, including changes in diatom, lichen, mycorrhizal fungal, and terrestrial plant communities. For example, in the Mediterranean California ecoregion, native plant species in some ecosystems have been replaced by invasive species more productive under elevated $\mathrm{N}$ deposition (Weiss 1999, Yoshida and Allen 2004, Fenn et al. 2010, Rao and Allen 2010, Rao et al. 2010). Such shifts in plant community composition and species richness can lead to overall losses in biodiversity and further impair particular threatened or endangered species (Stevens et al. 2004), as has occurred for the checkerspot butterfly (Weiss 1999).

\section{Critical loads definition and previous uses}

One method for evaluating potential impacts of air pollution on ecosystems is the critical load approach. The critical load is defined as "the deposition of a pollutant below which no detrimental ecological effect occurs over the long term according to present knowledge" (UBA 2004). The critical load is reported as a flux $\left(\mathrm{kg} \cdot \mathrm{ha}^{-1} \cdot \mathrm{yr}^{-1}\right)$. Critical loads have been used broadly in Europe (Posch et al. 1995, 2001) as a tool in the process of negotiating decreases in air pollution. Critical loads have been more widely applied in Canada than in the United States. In Canada, critical loads have been published for upland forests (Ouimet et al. 2006) and lakes (Dupont et al. 2005) in eastern Canada and included in European assessments (Hettelingh et al. 2008). In the United States, critical loads have been calculated for specific regions such as the Northeast (NEG/ECP 2003, Dupont et al. 2005), California (Fenn et al. 2003a, $b, 2008,2010$ ), Colorado (Williams and Tonnessen 2000, Baron 2006, Bowman et al. 2006), the Pacific Northwest (Geiser et al. 2010), and, at a coarse scale, the conterminous United States (McNulty et al. 2007). Critical loads have been determined most frequently in the United States for effects of acidity
(NEG/ECP 2003, Sullivan et al. 2005), but are also being increasingly used in evaluating impacts of $\mathrm{N}$ deposition on ecosystems in terms of excess nutrient $\mathrm{N}$ availability, also known as eutrophication (Fenn et al. 2008, 2010).

Despite relatively limited use in the United States, the critical loads approach is being explored at state, federal, and international levels as an ecosystem assessment tool with great potential to simplify complex scientific information and communicate effectively with the policy community and the public (Porter et al. 2005, Burns et al. 2008). The critical loads approach can provide a useful lens through which to assess the results of current policies and programs and to evaluate the potential ecosystem-protection value of proposed policy options. Critical loads are used by policymakers to inform the process of setting emissions standards, for assessing emissions control programs, and by natural resource managers as a tool to evaluate the potential impact of new pollution sources (Porter et al. 2005, U.S. EPA 2007, 2008, Burns et al. 2008, Environment Canada 2008, Lovett et al. 2009). Policymakers and resource managers have used critical loads to establish benchmarks for resource protection and to communicate the impacts of deposition on natural resource conditions.

There are three main approaches for estimating critical loads (Pardo 2010): empirical, steady-state mass balance (UBA 2004), and dynamic modeling (Slootweg et al. 2007, de Vries et al. 2010). Empirical critical loads are determined from observations of detrimental responses of an ecosystem or ecosystem component to an observed $\mathrm{N}$ deposition input (Pardo 2010). This level of $\mathrm{N}$ deposition is set as the critical load and extrapolated to other similar ecosystems. Empirical critical loads for $\mathrm{N}$ are based on measurements from gradient studies, field experiments, or observations from long-term studies (Bobbink et al. 1992, 2003, 2010). Steady-state mass balance modeling is based on estimating the net loss or accumulation of $\mathrm{N}$ inputs and outputs over the long term under the assumption that the ecosystem is at steady state with respect to $\mathrm{N}$ inputs. Dynamic models also use a mass balance approach, but consider timedependent processes and require detailed data sets for parameterization and testing (Belyazid et al. 2006, de Vries et al. 2007).

The advantage of the empirical approach is that it is based on measurable ecosystem responses to $\mathrm{N}$ inputs; however, the method will overestimate the critical load (set it too high) if the system has not reached steady state, i.e., if a similar response would occur at a lower deposition level over a longer period. The advantage of steady-state mass balance approaches is that they are less likely to overestimate the critical load. However, in the United States, the uncertainty associated with steady-state mass balance approaches is high because data are not available to quantify the terms in the mass balance equations accurately. Indeed, our empirical 
critical loads synthesis may be useful in defining the acceptable critical thresholds for application in steadystate mass balance critical loads calculations.

Dynamic models for critical loads of $\mathrm{N}$ in the United States have been applied on a limited basis ( $\mathrm{Wu}$ and Driscoll 2010). For dynamic modeling of nutrient $\mathrm{N}$ critical loads, empirical critical loads and other response data are essential. Here, too, current data have not been sufficient to develop, parameterize, and test dynamic models of ecosystem structure and function (including changes in biodiversity). Thus, empirical critical loads currently provide a uniquely valuable approach for assessing the risk of harm to ecosystems in the United States. This synthesis is a first step towards identifying which data are available for key ecosystems and where dynamic modeling could most profitably be applied in the United States after further data collection.

\section{Objectives}

Our recent publication (Pardo et al. 2011c) synthesized current research relating atmospheric $\mathrm{N}$ deposition to effects on terrestrial and freshwater ecosystems in the United States and quantified empirical critical loads for atmospheric $\mathrm{N}$ deposition, with one chapter devoted to each of 12 major ecoregions. Our objectives for this paper were to synthesize empirical critical loads for $\mathrm{N}$ reported for all the ecoregions of the United States, compare critical loads by life form or ecosystem compartment across all ecoregions, discuss the abiotic and biotic factors that affect the critical loads, and compare critical loads in the United States to those for similar ecoregions/ecosystems in Europe. Finally, we discuss the significance of these findings, and recommend priorities for future research.

\section{ApProACH}

For this synthesis, we reviewed studies of responses to $\mathrm{N}$ inputs (Pardo et al. 2011c) for U.S. ecoregions as defined by the Commission for Environmental Cooperation (CEC) Level I ecoregions map for North America (Fig. 1; CEC 1997). We identified the receptor of concern (organism or ecosystem compartment), the response of concern, the critical threshold value for that response, and the criteria for setting the critical load and extrapolating the critical load to other sites or regions. These methods are described in detail in Pardo et al. (2011b) and the Appendix.

The receptors evaluated included freshwater diatoms, mycorrhizal fungi, lichenized fungi (henceforth lichens), bryophytes, herbaceous plants, shrubs, and trees. Ecosystem impacts included: (1) biogeochemical responses and (2) individual species, population, and community responses. Biogeochemical responses included increased $\mathrm{N}$ mineralization and nitrification (and $\mathrm{N}$ availability for plant and microbial uptake), increased gaseous $\mathrm{N}$ losses (ammonia volatilization, nitrous oxide from nitrification and denitrification), and increased $\mathrm{N}$ leaching. Individual species, population, and community responses included increased tissue $\mathrm{N}$ concentration, physiological and nutrient imbalances, altered growth, altered root: shoot ratios, increased susceptibility to secondary stresses, altered fire regimes, changes in species abundance, shifts in competitive interactions and community composition (including shifts within and across diatom, bacterial, fungal, or plant taxa groups), changes in species richness and other measures of biodiversity, and increases in invasive species.

We considered $\mathrm{N}$ addition, $\mathrm{N}$ deposition gradient, and long-term monitoring studies in order to evaluate ecosystem response to $\mathrm{N}$ deposition inputs. Most of these studies were not designed to quantify critical loads, which presented some challenges. We afforded greater weight to long-term fertilization studies (5-10 years) than to short-term studies. Single-dose forest fertilization studies exceeding $50 \mathrm{~kg} \mathrm{~N} /$ ha were generally not considered, although lower dose short-term studies were considered when other observations were limited. When $\mathrm{N}$-addition studies were designed in order to determine critical loads, the studies generally included modest $\mathrm{N}$ additions; multiple (three or more) treatment levels with smaller increments between the treatment levels; and treatments spanning the critical load. In such cases, estimates of the critical load are made with greater certainty than for other types of $\mathrm{N}$-addition studies. Nitrogen gradient studies implicitly include longer term exposure to pollutants and therefore are more likely than $\mathrm{N}$ manipulation studies to depict conditions that are near steady state with respect to ambient $\mathrm{N}$ inputs. Long-term monitoring studies sometimes offer the opportunity to observe changes over time in response to increasing or elevated $\mathrm{N}$ deposition inputs. We estimated critical loads based on data from $>3200$ sites (Fig. 2).

In general, we determined the critical load based on the observed response pattern to $\mathrm{N}$ inputs. In some cases, there was a clear dose-response relationship where the response changed above a certain threshold. A critical threshold is the value of a response parameter which represents an unacceptable condition. The critical threshold is also referred to as the critical limit (UBA 2004). In other cases, when response to increasing $N$ was more linear, we estimated the "pristine" state of $\mathrm{N}$ deposition and the deposition that corresponded to a departure from that state. The criteria for setting critical loads are discussed in detail in Pardo et al. $(2011 b, c)$ and in the Appendix.

\section{Deposition}

Total $\mathrm{N}$ emissions in the U.S. have increased significantly since the 1950s (Galloway 1998, Galloway et al. 2003). As $\mathrm{S}$ deposition has declined in response to regulation, the rate of $\mathrm{N}$ deposition relative to $\mathrm{S}$ deposition has increased since the 1980s (Driscoll et al. 2001, 2003), followed by a general decrease in $\mathrm{NO}_{x}$ emissions from electric utilities since the early 2000s. More recently, the relative proportion of $\mathrm{NH}_{x}\left(\mathrm{NH}_{4}^{+}+\right.$ 


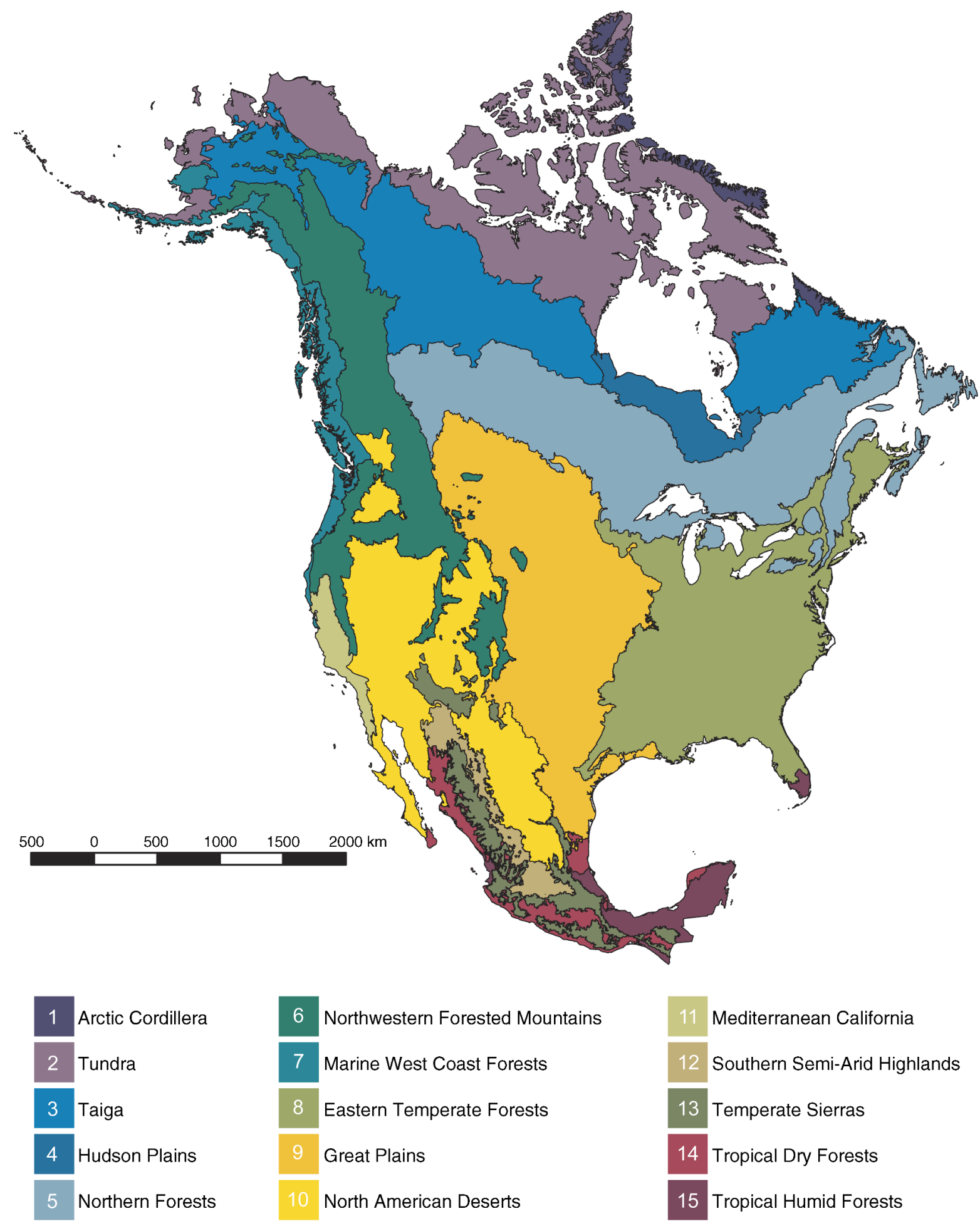

FIG. 1. Ecological regions of North America, Level I, adapted from the Commission for Environmental Cooperation (CEC 1997).

$\left.\mathrm{NH}_{3}\right)$ to $\mathrm{NO}_{x}\left(\mathrm{NO}+\mathrm{NO}_{2}\right)$ emissions has also increased for many areas of the United States (Kelly et al. 2005, Lehmann et al. 2005). Nitrogen deposition at sites included in this analysis (Weathers and Lynch 2011) was quantified by the Community Multiscale Air Quality (CMAQ) model v.4.3 simulations of wet + dry deposition of oxidized $\left(\mathrm{NO}_{y}\right)$ and reduced $\left(\mathrm{NH}_{x}\right) \mathrm{N}$ species (Fig. 2; hereafter CMAQ 2001 model; which uses 


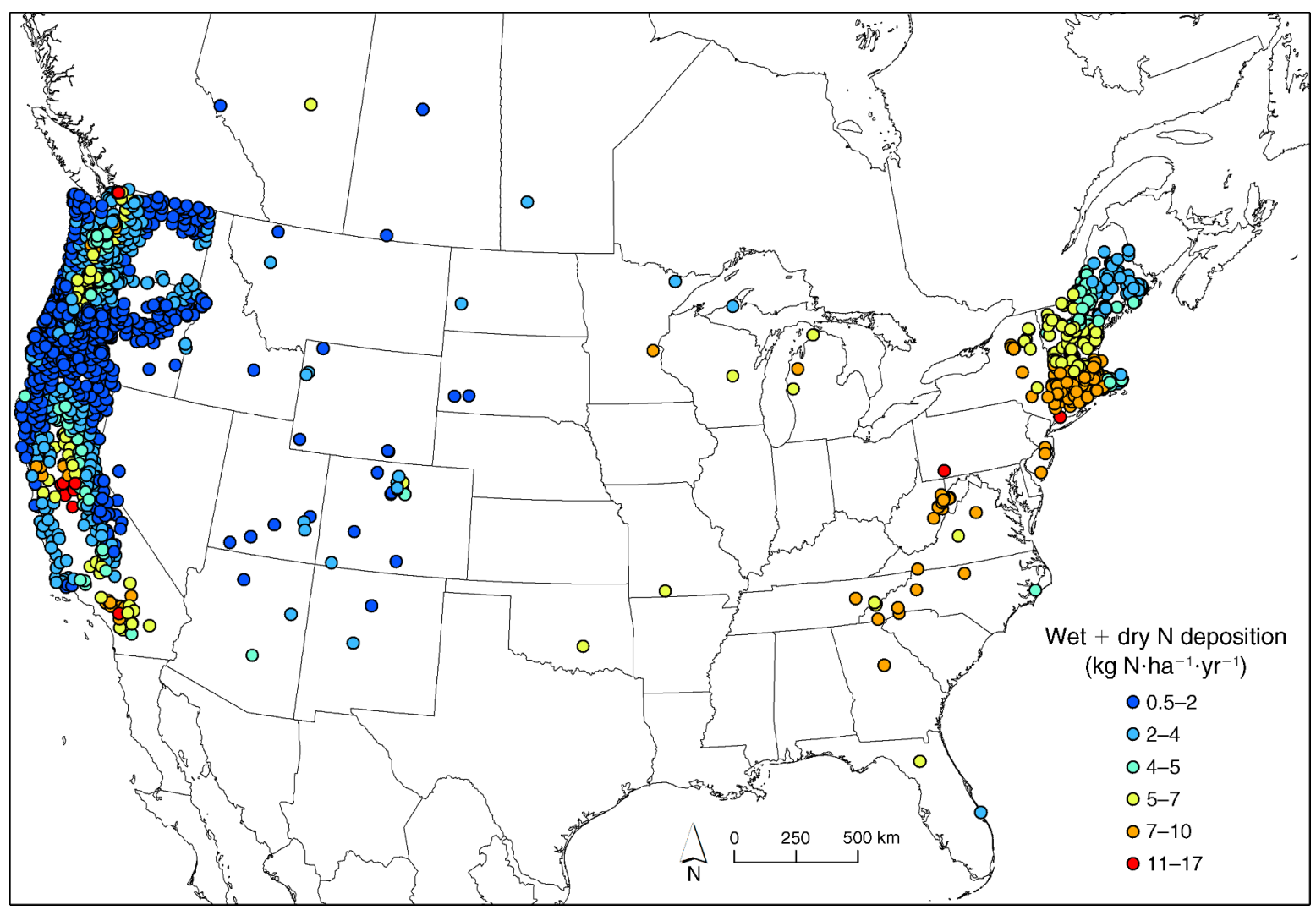

FIG. 2. Locations of the $>3200$ sites for which we report ecological responses to $\mathrm{N}$ deposition, labeled with estimates of wet + dry nitrogen $(\mathrm{N})$ deposition (includes wet ammonium and nitrate, dry nitric acid, particulate nitrate and ammonium, and gaseous ammonia, but not organic forms) generated by the Community Multiscale Air Quality (CMAQ) 2001 model. In some areas of elevated $\mathrm{N}$ deposition, CMAQ at this grid scale $(36 \mathrm{~km})$ likely underestimates total $\mathrm{N}$ deposition. This is the case, for example, over much of California (Fenn et al. 2010).

2001 reported data; Byun and Ching 1999, Byun and Schere 2006). These CMAQ data were used to calculate exceedance. Exceedance of the critical load is defined as the current deposition minus the critical load; when exceedance is greater than zero, the ecosystem is susceptible to harmful ecological effects. Exceedance is useful in communicating the extent of risk to ecosystems under current and future deposition scenarios.

We rarely had data to distinguish biotic or ecosystem response to reduced forms vs. oxidized forms of $\mathrm{N}$. There is some evidence that, for some species, reduced forms of $\mathrm{N}$ may have more substantial impacts than oxidized forms (Bobbink et al. 2003, Kleijn et al. 2008, Cape et al. 2009, Sutton et al. 2009). Differences in uptake rates and preference for $\mathrm{NH}_{4}{ }^{+}$vs. $\mathrm{NO}_{3}{ }^{-}$across different plant taxa (Falkengren-Grerup 1995, McKane et al. 2002, Miller and Bowman 2002, Nordin et al. 2006) lead to differences in sensitivity to $\mathrm{NH}_{x}$ (Krupa 2003) and $\mathrm{NO}_{y}$. However, not all species are more sensitive to $\mathrm{NH}_{x}$ than $\mathrm{NO}_{y}$ (S. Jovan, unpublished data); these responses vary by species and functional type. Some species are more sensitive to increases in $\mathrm{NO}_{y}$, as was demonstrated for boreal forests (Nordin et al. 2006).
In order to quantify the critical load, we generally used the deposition reported in the publication or, when that was not available, we used modeled deposition (e.g., CMAQ, ClimCalc [Ollinger et al. 1993], or National Atmospheric Deposition Program [NADP; NADP 2009]). The different forms of $\mathrm{N}$ deposition included in this assessment were: wet, bulk, wet+dry, throughfall, and total inorganic $\mathrm{N}$ deposition (wet+dry+cloud/fog). Total $\mathrm{N}$ deposition was considered the most appropriate value to use in evaluating ecosystem responses; however, in many studies this information is not available. Throughfall $\mathrm{N}$ is generally considered a good surrogate for total $\mathrm{N}$ deposition (Weathers et al. 2001), because it typically does not underestimate total $\mathrm{N}$ inputs as much as wet or bulk deposition. However, because of the potential for canopy uptake of $\mathrm{N}$, throughfall is usually considered as a lower bound estimate of total $\mathrm{N}$ deposition. None of the studies included reported inputs of organic $\mathrm{N}$, so this report focuses on responses to inputs of inorganic $\mathrm{N}$.

The accuracy of the atmospheric $\mathrm{N}$ deposition estimates clearly influences the accuracy of the critical load and exceedance estimates. Several factors contribute to uncertainty in $\mathrm{N}$ deposition estimates: (1) the 
difficulty of quantifying dry deposition of nitrogenous gases and particles to complex surfaces; and (2) sparse data, particularly for arid, highly heterogeneous terrain (e.g., mountains), and (3) sites with high snowfall or high cloudwater/fog deposition, where $\mathrm{N}$ deposition tends to be underestimated. Deposition models cannot account for these kinds of heterogeneity (e.g., Weathers et al. 2006) because the spatial scale (grid size) is typically too coarse to capture topographic and other local influences. These issues are discussed in detail elsewhere (Weathers et al. 2006, Fenn et al. 2009, Weathers and Lynch 2011). When more accurate and precise $\mathrm{N}$ deposition estimates become available, the data presented in this study may be reevaluated in order to refine the critical loads estimates.

\section{Results AND Discussion}

The range of critical loads for nutrient $\mathrm{N}$ reported for the United States ecoregions, inland surface waters, and freshwater wetlands is $1-39 \mathrm{~kg} \mathrm{~N} \cdot \mathrm{ha}^{-1} \cdot \mathrm{yr}^{-1}$ (Table 1). This broad range spans the range of $\mathrm{N}$ deposition observed over most of the country (see Weathers and Lynch 2011). For coastal wetlands, critical loads are between $50-400 \mathrm{~kg} \mathrm{~N} \cdot \mathrm{ha}^{-1} \cdot \mathrm{yr}^{-1}$. The number of locations for which ecosystem response data were available (Fig. 2) for an ecoregion was variable, which impacts the level of certainty of the empirical critical loads estimates. Details on the studies upon which the critical loads values (Tables 1 and 2) are based are provided in Pardo et al. (2011c).

\section{Comparison of critical load by receptor across ecoregions}

Because $\mathrm{N}$ deposition varies considerably by region and the critical load varies both by region and receptor, we present the critical loads and likely risk of exceedance by receptor.

\section{Mycorrhizal fungi.-}

1. Background.-Mycorrhizal fungi reside at the interface between host plants and soils, exchanging soil resources, especially nutrients, with host plants in exchange for photosynthates (carbon compound). Due to this important and unique ecological niche, mycorrhizal fungi are at particular risk due to changes in either the soil environment or host carbon allocation.

2. Response to N.-Nitrogen deposition adversely affects mycorrhizal fungi (1) by causing decreased belowground $\mathrm{C}$ allocation by hosts and increased $\mathrm{N}$ uptake and associated metabolic costs (Wallander 1995) and (2) via soil chemical changes associated with eutrophication and acidification. There are two major groups of mycorrhizal fungi that are evolutionarily and ecologically distinct: arbuscular mycorrhizal fungi (AMF) and ectomycorrhizal fungi (EMF). Under sufficiently high $\mathrm{N}$ inputs, the progressive effect of elevated $\mathrm{N}$ is an early decline of sporocarp (reproductive structure) production for EMF and spore production for $\mathrm{AMF}$, and subsequent decline in biological diversity and loss of taxa adapted to N-poor environments or sensitive to acidification (Lilleskov 2005). Sporocarp and spore production appears to be especially sensitive to $\mathrm{N}$ deposition, often declining before the communities on root tips have been substantially altered, presumably because sporocarps and spores are at the end of the carbon flux pathway from hosts.

Of the two plant-fungal symbioses examined here, mycorrhizal fungi (Table 3) appear to be less sensitive to $\mathrm{N}$ deposition than lichens (Table 4), presumably because the soil environment buffers these soil fungi from some of the immediate impacts of $\mathrm{N}$ deposition, to which lichens are directly exposed. Lichens have an advantage as indicators when compared with mycorrhizal fungi because they can be relatively easily inventoried. However, the critical role of mycorrhizal fungi as root symbionts central to plant nutrition and belowground production, and, in forests, as repositories of a large part of the eukaryote diversity, as major components of food webs, and as non-timber forest products of high economic value (edible sporocarps or mushrooms; Amaranthus 1998) provides sufficient impetus to improve our understanding of their response to $\mathrm{N}$ deposition.

3. Critical loads.-We reviewed empirical studies on mycorrhizal fungal response to $\mathrm{N}$ inputs as the basis for determining empirical critical loads for the United States (Table 3, Fig. 3a). Despite the sparse data, it is clear that $\mathrm{N}$ deposition sufficient to elevate inorganic $\mathrm{N}$, especially $\mathrm{NO}_{3}{ }^{-}$, availability in soils can have measurable effects on mycorrhizal fungi. The data for EMF indicate that $\mathrm{N}$ deposition to N-limited conifer forests in the range of 5$10 \mathrm{~kg} \mathrm{~N} \cdot \mathrm{ha}^{-1} \cdot \mathrm{yr}^{-1}$ can significantly alter community structure and composition and decrease species richness (Lilleskov 1999, Lilleskov et al. 2001, 2002, 2008, Dighton et al. 2004). Similarly, the data for AMF suggest $\mathrm{N}$ deposition levels of $7.8-12 \mathrm{~kg} \mathrm{~N} \cdot \mathrm{ha}^{-1} \cdot \mathrm{yr}^{-1}$ can lead to community changes, declines in spore abundance and root colonization, and changes in community function, based on reanalysis of data from EgertonWarburton et al. (2001) combined with $\mathrm{N}$ deposition data, and decreases in fungal abundance (van Diepen et al. 2007, van Diepen 2008) and declines in fungal activity (L. M. Egerton-Warburton, unpublished data). The actual threshold for $\mathrm{N}$ effects on AMF could be even lower, because high background deposition precludes consideration of sites receiving deposition at or near preindustrial levels. Therefore, our provisional expert judgment is that critical loads for mycorrhizal diversity for sensitive ecosystem types are $5-10 \mathrm{~kg} \mathrm{~N} \cdot \mathrm{ha}^{-1} \cdot \mathrm{yr}^{-1}$. The uncertainty of this estimate is high, because few studies have been conducted at low $\mathrm{N}$ deposition to further refine the critical load. The critical load of $\mathrm{N}$ for mycorrhizal fungi, when community change occurs, is often on the order of current $\mathrm{N}$ deposition, and thus, is exceeded across most of the eastern and northern forests and in regions downwind of agricultural and urban emissions in the West (Fig. 3b). The uncertainty associated with the exceedance, like that for the critical load, is high. 
TABLE 1. Summary of critical loads (CL) of nutrient $\mathrm{N}$ for North American ecoregions.

\begin{tabular}{|c|c|c|c|c|c|c|}
\hline Ecoregion & $\begin{array}{l}\text { Ecosystem } \\
\text { component }\end{array}$ & $\begin{array}{l}\text { CL for N } \\
\text { deposition } \\
(\mathrm{kg} \mathrm{N} \cdot \\
\left.\mathrm{ha}^{-1} \cdot \mathrm{yr}^{-1}\right)\end{array}$ & Reliability† & Response & Comments & Study \\
\hline Tundra & $\begin{array}{l}\text { prostrate } \\
\text { dwarf } \\
\text { shrubs }\end{array}$ & $1-3$ & \#\# & $\begin{array}{l}\text { changes in } \mathrm{CO}_{2} \\
\text { exchange, cover, } \\
\text { foliar } \mathrm{N} \text {, and } \\
\text { community } \\
\text { composition of } \\
\text { vascular plants }\end{array}$ & $\begin{array}{l}\mathrm{N} \text { addition study, } \\
\text { Greenland high } \\
\text { arctic, } \mathrm{P} \text { enhanced } \\
\mathrm{N} \text { effects }\end{array}$ & $\begin{array}{l}\text { Arens et al. } \\
\quad(2008) \ddagger\end{array}$ \\
\hline Tundra & lichens & $1-3$ & $(\#)$ & $\begin{array}{l}\text { changes in lichen } \\
\text { pigment production } \\
\text { and ultrastructure, } \\
\text { changes in lichen } \\
\text { and bryophyte } \\
\text { cover }\end{array}$ & $\begin{array}{l}\mathrm{N} \text { addition studies, } \\
\text { high and low arctic, } \\
\mathrm{P} \text { enhanced or } \\
\text { moderated } \mathrm{N} \text { effects }\end{array}$ & $\begin{array}{l}\text { Hyvärinen et al. } \\
\text { (2003),§ } \\
\text { Makkonen et al. } \\
\text { (2007),§ Arens } \\
\text { et al. (2008) } \ddagger\end{array}$ \\
\hline Taiga & forest & $1-3$ & \# & $\begin{array}{l}\text { changes in alga, } \\
\text { bryophyte, and } \\
\text { lichen community } \\
\text { composition, cover, } \\
\text { tissue } \mathrm{N} \text {, or growth } \\
\text { rates }\end{array}$ & & $\begin{array}{l}\text { Poikolainen et al. } \\
\text { (1998),§ } \\
\text { Strengbom et al. } \\
(2003), \Phi \text { Vitt et } \\
\text { al. (2003),\| } \\
\text { Berryman et al. } \\
\text { (2004), } \| \text { Moore } \\
\text { et al. (2004),\| } \\
\text { Berryman and } \\
\text { Straker (2008), || } \\
\text { Geiser et al. } \\
\text { (2010) }\end{array}$ \\
\hline Taiga & spruce forests & $5-7$ & $(\#)$ & $\begin{array}{l}\text { change in ecto- } \\
\text { mycorrhizal fungal } \\
\text { community } \\
\text { structure }\end{array}$ & $\begin{array}{l}\text { expert judgment } \\
\text { extrapolated from } \\
\text { Marine West Coast } \\
\text { spruce and northern } \\
\text { spruce-fir forest }\end{array}$ & $\begin{array}{l}\text { Lilleskov (1999), } \\
\text { Lilleskov et al. } \\
\text { (2001, 2002, } \\
\text { 2008) }\end{array}$ \\
\hline Taiga & shrublands & 6 & \#\# & $\begin{array}{l}\text { change in shrub and } \\
\text { grass cover, in- } \\
\text { creased parasitism } \\
\text { of shrubs }\end{array}$ & $\begin{array}{l}\text { long-term, low-N } \\
\text { addition study: } \\
\text { shrub cover } \\
\text { decreased, grass } \\
\text { cover increased }\end{array}$ & $\begin{array}{l}\text { Strengbom et al. } \\
\text { (2003), Nordin } \\
\text { et al. }(2005)\end{array}$ \\
\hline $\begin{array}{l}\text { Northern } \\
\text { Forests }\end{array}$ & $\begin{array}{l}\text { hardwood } \\
\text { and } \\
\text { coniferous } \\
\text { forests }\end{array}$ & $>3$ & $\#$ & $\begin{array}{l}\text { decreased growth of } \\
\text { red pine, and de- } \\
\text { creased survivor- } \\
\text { ship of yellow } \\
\text { birch, scarlet and } \\
\text { chestnut oak, } \\
\text { quaking aspen, and } \\
\text { basswood }\end{array}$ & & $\begin{array}{l}\text { Thomas et al. } \\
\text { (2010) }\end{array}$ \\
\hline $\begin{array}{l}\text { Northern } \\
\text { Forests }\end{array}$ & lichens & $4-6$ & $(\#)$ & $\begin{array}{l}\text { epiphytic lichen } \\
\text { community change }\end{array}$ & $\begin{array}{l}\text { loss of oligotrophic } \\
\text { species, synergistic/ } \\
\text { confounding effects } \\
\text { of acidic deposition } \\
\text { not considered; } \\
\text { assumes response } \\
\text { threshold similar to } \\
\text { Marine West Coast } \\
\text { Forests }\end{array}$ & Geiser et al. (2010) \\
\hline $\begin{array}{l}\text { Northern } \\
\text { Forests }\end{array}$ & $\begin{array}{l}\text { ectomycor- } \\
\text { rhizal fungi }\end{array}$ & $5-7$ & \# & $\begin{array}{l}\text { change in fungal } \\
\text { community } \\
\text { structure }\end{array}$ & & $\begin{array}{l}\text { Lilleskov et al. } \\
\text { (2008) }\end{array}$ \\
\hline $\begin{array}{l}\text { Northern } \\
\text { Forests }\end{array}$ & $\begin{array}{l}\text { herbaceous } \\
\text { cover } \\
\text { species }\end{array}$ & $\begin{array}{l}>7 \text { and } \\
<21\end{array}$ & \# & $\begin{array}{l}\text { loss of prominent } \\
\text { species }\end{array}$ & $\begin{array}{l}\text { response observed in } \\
\text { low-level } \\
\text { fertilization } \\
\text { experiment }\end{array}$ & Hurd et al. (1998) \\
\hline $\begin{array}{l}\text { Northern } \\
\text { Forests }\end{array}$ & $\begin{array}{l}\text { hardwood } \\
\text { and } \\
\text { coniferous } \\
\text { forests }\end{array}$ & 8 & \#\# & $\begin{array}{l}\text { increased surface } \\
\text { water } \mathrm{NO}_{3}^{-} \\
\text {leaching }\end{array}$ & & Aber et al. (2003) \\
\hline $\begin{array}{l}\text { Northern } \\
\text { Forests }\end{array}$ & $\begin{array}{l}\text { old-growth } \\
\text { montane } \\
\text { red spruce }\end{array}$ & $\begin{array}{l}>10 \text { and } \\
<26\end{array}$ & \# & $\begin{array}{l}\text { decreased growth and/ } \\
\text { or induced } \\
\text { mortality }\end{array}$ & $\begin{array}{l}\text { response observed in } \\
\text { low-level } \\
\text { fertilization } \\
\text { experiment }\end{array}$ & $\begin{array}{l}\text { McNulty et al. } \\
(2005)\end{array}$ \\
\hline
\end{tabular}


Table 1. Continued.

\begin{tabular}{|c|c|c|c|c|c|c|}
\hline Ecoregion & $\begin{array}{l}\text { Ecosystem } \\
\text { component }\end{array}$ & $\begin{array}{c}\text { CL for N } \\
\text { deposition } \\
(\mathrm{kg} \mathrm{N} \cdot \\
\left.\mathrm{ha}^{-1} \cdot \mathrm{yr}^{-1}\right)\end{array}$ & Reliability† & Response & Comments & Study \\
\hline $\begin{array}{l}\text { Northern } \\
\text { Forests }\end{array}$ & $\mathrm{AMF}$ & $<12$ & $(\#)$ & $\begin{array}{l}\text { biomass decline and } \\
\text { community } \\
\text { composition change }\end{array}$ & & $\begin{array}{l}\text { van Diepen et al. } \\
\text { (2007), van } \\
\text { Diepen (2008) }\end{array}$ \\
\hline $\begin{array}{l}\text { Northwestern } \\
\text { Forested } \\
\text { Mountains }\end{array}$ & alpine lakes & 1.5 & \#\# & $\begin{array}{l}\text { changes in diatom } \\
\text { assemblages }\end{array}$ & $\begin{array}{l}\text { as wet deposition } \\
\text { only }\end{array}$ & Baron (2006) \\
\hline $\begin{array}{l}\text { Northwestern } \\
\text { Forested } \\
\text { Mountains }\end{array}$ & lichens & $1.2-3.7$ & $(\#)$ & $\begin{array}{l}\text { epiphytic lichen } \\
\text { community change } \\
\text { in mixed-conifer } \\
\text { forests, Alaska }\end{array}$ & $\begin{array}{l}\text { application of } \\
\text { western Oregon } \\
\text { and Washington } \\
\text { model }\end{array}$ & Geiser et al. (2010) \\
\hline $\begin{array}{l}\text { Northwestern } \\
\text { Forested } \\
\text { Mountains }\end{array}$ & lichens & $2.5-7.1$ & \#\# & $\begin{array}{l}\text { epiphytic lichen } \\
\text { community change, } \\
\text { thallus N } \\
\text { enrichment in } \\
\text { mixed-conifer } \\
\text { forests, non-Alaska }\end{array}$ & & $\begin{array}{l}\text { Fenn et al. (2008), } \\
\text { Geiser et al. } \\
\text { (2010) }\end{array}$ \\
\hline $\begin{array}{l}\text { Northwestern } \\
\text { Forested } \\
\text { Mountains }\end{array}$ & $\begin{array}{l}\text { subalpine } \\
\text { forest }\end{array}$ & 4 & \#\# & $\begin{array}{l}\text { increase in organic } \\
\text { horizon } \mathrm{N} \text {, foliar } \\
\mathrm{N} \text {, potential net } \mathrm{N} \\
\text { mineralization, and } \\
\text { soil solution } \mathrm{N}, \\
\text { initial increases in } \\
\mathrm{N} \text { leaching below } \\
\text { the organic layer }\end{array}$ & & $\begin{array}{l}\text { Baron et al. } \\
(1994) \text {, Rueth } \\
\text { and Baron } \\
(2002)\end{array}$ \\
\hline $\begin{array}{l}\text { Northwestern } \\
\text { Forested } \\
\text { Mountains }\end{array}$ & alpine lakes & 4.0 & \# & $\begin{array}{l}\text { episodic freshwater } \\
\text { acidification }\end{array}$ & & $\begin{array}{l}\text { Williams and } \\
\text { Tonnesson } \\
(2000)\end{array}$ \\
\hline $\begin{array}{l}\text { Northwestern } \\
\text { Forested } \\
\text { Mountains }\end{array}$ & $\begin{array}{l}\text { alpine } \\
\text { grassland }\end{array}$ & $4-10$ & \#\# & $\begin{array}{l}\text { changes in plant } \\
\text { species composition }\end{array}$ & & $\begin{array}{l}\text { Bowman et al. } \\
(2006)\end{array}$ \\
\hline $\begin{array}{l}\text { Northwestern } \\
\text { Forested } \\
\text { Mountains }\end{array}$ & $\begin{array}{l}\text { ectomy- } \\
\text { corrhizal } \\
\text { fungi }\end{array}$ & $5-10$ & $(\#)$ & $\begin{array}{l}\text { changes in ecto- } \\
\text { mycorrhizal fungi } \\
\text { community } \\
\text { structure in white, } \\
\text { black, and Engel- } \\
\text { mann spruce forests }\end{array}$ & $\begin{array}{l}\text { expert judgment } \\
\text { extrapolated from } \\
\text { Marine West } \\
\text { Coast spruce and } \\
\text { northern spruce-- } \\
\text { fir forest }\end{array}$ & $\begin{array}{l}\text { Lilleskov (1999), } \\
\text { Lilleskov et al. } \\
\text { (2001, 2002, } \\
\text { 2008) }\end{array}$ \\
\hline $\begin{array}{l}\text { Northwestern } \\
\text { Forested } \\
\text { Mountains }\end{array}$ & $\begin{array}{l}\text { mixed-conifer } \\
\text { forest }\end{array}$ & 17 & $\begin{array}{c}\# \# \\
\#\end{array}$ & $\begin{array}{l}\mathrm{NO}_{3}^{-} \text {leaching, } \\
\text { reduced fine-root } \\
\text { biomass }\end{array}$ & & Fenn et al. (2008) \\
\hline $\begin{array}{l}\text { Marine West } \\
\text { Coast } \\
\text { Forests }\end{array}$ & $\begin{array}{l}\text { western } \\
\text { Oregon } \\
\text { and Wash- } \\
\text { ington } \\
\text { forests }\end{array}$ & $2.7-9.2$ & \#\# & $\begin{array}{l}\text { epiphytic lichen com- } \\
\text { munity change }\end{array}$ & $\begin{array}{l}\text { loss of oligo- } \\
\text { trophic species, } \\
\text { enhancement of } \\
\text { eutrophic species, } \\
\text { CL increases with } \\
\text { regional range in } \\
\text { mean annual } \\
\text { precipitation from } \\
45 \text { to } 450 \mathrm{~cm}\end{array}$ & Geiser et al. (2010) \\
\hline $\begin{array}{l}\text { Marine West } \\
\text { Coast } \\
\text { Forests }\end{array}$ & $\begin{array}{l}\text { southeastern } \\
\text { Alaska } \\
\text { forests }\end{array}$ & 5 & (\#) & $\begin{array}{l}\text { fungal community } \\
\text { change, declines in } \\
\text { ectomycorrhizal } \\
\text { fungal diversity }\end{array}$ & & $\begin{array}{l}\text { Whytemare et al. } \\
\text { (1997), Lilleskov } \\
\text { (1999), Lilleskov } \\
\text { et al. (2001, } \\
\text { 2002) }\end{array}$ \\
\hline $\begin{array}{l}\text { Eastern } \\
\text { Temperate } \\
\text { Forest }\end{array}$ & $\begin{array}{l}\text { eastern } \\
\text { hardwood } \\
\text { forest }\end{array}$ & $>3$ & \# & $\begin{array}{l}\text { decreased growth of } \\
\text { red pine, and } \\
\text { decreased } \\
\text { survivorship of } \\
\text { yellow birch, scarlet } \\
\text { and chestnut oak, } \\
\text { quaking aspen, and } \\
\text { basswood }\end{array}$ & & $\begin{array}{l}\text { Thomas et al. } \\
\text { (2010) }\end{array}$ \\
\hline
\end{tabular}


TABle 1. Continued.

\begin{tabular}{|c|c|c|c|c|c|c|}
\hline Ecoregion & $\begin{array}{l}\text { Ecosystem } \\
\text { component }\end{array}$ & 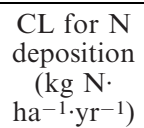 & Reliability & Response & Comments & Study \\
\hline $\begin{array}{l}\text { Eastern } \\
\text { Temperate } \\
\text { Forest }\end{array}$ & lichens & $4-8$ & $(\#)$ & $\begin{array}{l}\text { epiphytic lichen } \\
\text { community change }\end{array}$ & $\begin{array}{l}\text { loss of oligotrophic } \\
\text { species, synergistic/ } \\
\text { confounding effects } \\
\text { of acidic deposition } \\
\text { not considered; } \\
\text { based on } \\
\text { application of } \\
\text { model and } \\
\text { estimated response } \\
\text { threshold }\end{array}$ & Geiser et al. (2010) \\
\hline $\begin{array}{l}\text { Eastern } \\
\text { Temperate } \\
\text { Forest }\end{array}$ & $\begin{array}{l}\text { Southeastern } \\
\text { Coastal } \\
\text { Plain }\end{array}$ & $5-10$ & (\#) & $\begin{array}{l}\text { ectomycorrhizal fungi } \\
\text { community change }\end{array}$ & & $\begin{array}{l}\text { Lilleskov et al. } \\
\text { (2001, 2002, } \\
\text { 2008), Dighton } \\
\text { et al. (2004) }\end{array}$ \\
\hline $\begin{array}{l}\text { Eastern } \\
\text { Temperate } \\
\text { Forest }\end{array}$ & $\begin{array}{l}\text { eastern } \\
\text { hardwood } \\
\text { forests }\end{array}$ & 8 & \#\# & $\begin{array}{l}\text { increased surface } \\
\text { water } \mathrm{NO}_{3}^{-} \\
\text {leaching }\end{array}$ & & Aber et al. (2003) \\
\hline $\begin{array}{l}\text { Eastern } \\
\text { Temperate } \\
\text { Forest }\end{array}$ & $\begin{array}{l}\text { Michigan } \\
\text { deposition } \\
\text { gradient }\end{array}$ & $<12$ & $(\#)$ & $\begin{array}{l}\text { AMF biomass decline } \\
\text { and community } \\
\text { composition change }\end{array}$ & & $\begin{array}{l}\text { van Diepen et al. } \\
\text { (2007), van } \\
\text { Diepen }(2008)\end{array}$ \\
\hline $\begin{array}{l}\text { Eastern } \\
\text { Temperate } \\
\text { Forest }\end{array}$ & $\begin{array}{l}\text { herbaceous } \\
\text { species }\end{array}$ & $<17.5$ & $(\#)$ & $\begin{array}{l}\text { increases in nitrophilic } \\
\text { species, declines in } \\
\text { species-rich genera } \\
\text { (e.g., Viola) }\end{array}$ & & $\begin{array}{l}\text { Gilliam (2006, } \\
\text { 2007), Gilliam } \\
\text { et al. (2006) }\end{array}$ \\
\hline Great Plains & $\begin{array}{l}\text { tallgrass } \\
\text { prairie }\end{array}$ & $5-15$ & \# & $\begin{array}{l}\text { biogeochemical N } \\
\text { cycling, plant and } \\
\text { insect community } \\
\text { shifts }\end{array}$ & & $\begin{array}{l}\text { Tilman (1987, } \\
\text { 1993), Wedin } \\
\text { and Tilman } \\
\text { (1996), Clark } \\
\text { and Tilman } \\
\text { (2008), Clark et } \\
\text { al. (2009) }\end{array}$ \\
\hline Great Plains & $\begin{array}{l}\text { mixed-grass } \\
\text { prairie }\end{array}$ & $10-25$ & \# & $\begin{array}{l}\text { soil } \mathrm{NO}_{3}^{-} \text {pools, } \\
\text { leaching, plant } \\
\text { community shifts }\end{array}$ & & $\begin{array}{l}\text { Clark et al. (2003, } \\
\text { 2005), Jorgensen } \\
\text { et al. (2005) }\end{array}$ \\
\hline Great Plains & $\begin{array}{l}\text { short-grass } \\
\text { prairie }\end{array}$ & $10-25$ & (\#) & & $\begin{array}{l}\text { inferred from mixed- } \\
\text { grass prairie }\end{array}$ & $\begin{array}{l}\text { Epstein et al. } \\
(2001), \text { Barret } \\
\text { and Burke } \\
(2002)\end{array}$ \\
\hline Great Plains & $\begin{array}{l}\text { mycorrhizal } \\
\text { fungi }\end{array}$ & 12 & $(\#)$ & $\begin{array}{l}\text { decline in arbuscular } \\
\text { mycorrhizal fungal } \\
\text { activity }\end{array}$ & & $\begin{array}{l}\text { L. M. Egerton- } \\
\text { Warburton, } \\
\text { unpublished data }\end{array}$ \\
\hline $\begin{array}{l}\text { North American } \\
\text { Desert }\end{array}$ & lichens & 3 & $(\#)$ & $\begin{array}{l}\text { lichen community } \\
\text { shifts, thallus } \mathrm{N} \\
\text { concentration }\end{array}$ & $\begin{array}{l}\text { uncertainty regarding } \\
\text { modeled deposition } \\
\text { estimates }\end{array}$ & $\begin{array}{l}\text { Porter (2007), } \\
\text { Geiser et al. } \\
\text { (2008) }\end{array}$ \\
\hline $\begin{array}{l}\text { North American } \\
\text { Desert }\end{array}$ & $\begin{array}{l}\text { shrubland, } \\
\text { woodland, } \\
\text { desert } \\
\text { grassland }\end{array}$ & $3-8.4$ & \# & $\begin{array}{l}\text { vegetation response, } \\
\text { vascular plant } \\
\text { community change }\end{array}$ & & $\begin{array}{l}\text { Inouye (2006), } \\
\text { Baez et al. } \\
\text { (2007), Allen et } \\
\text { al. (2009), Rao } \\
\text { et al. (2010) }\end{array}$ \\
\hline $\begin{array}{l}\text { Mediterranean } \\
\text { California }\end{array}$ & $\begin{array}{l}\text { coastal sage } \\
\text { scrub }\end{array}$ & $7.8-10$ & \# & $\begin{array}{l}\text { invasive grass cover, } \\
\text { native forb richness, } \\
\text { AMF richness }\end{array}$ & $\begin{array}{l}\text { modeled and } \\
\text { inferential N } \\
\text { deposition estimates } \\
\text { and published data } \\
\text { for mycorrhizae; } \\
\text { unpublished data for } \\
\text { vegetation survey }\end{array}$ & $\begin{array}{l}\text { Egerton- } \\
\text { Warburton and } \\
\text { Allen }(2000) \text {, } \\
\text { Tonnesen et al. } \\
\text { (2007), Fenn et } \\
\text { al. (2010) }\end{array}$ \\
\hline $\begin{array}{l}\text { Mediterranean } \\
\text { California }\end{array}$ & $\begin{array}{c}\text { chaparral; } \\
\text { lichens }\end{array}$ & $3-6$ & \# & $\begin{array}{l}\text { epiphytic lichen } \\
\text { community change }\end{array}$ & $\begin{array}{l}\text { lichen CL from } \\
\text { modeled N } \\
\text { deposition data and } \\
\text { published data for } \\
\text { lichens }\end{array}$ & $\begin{array}{l}\text { Jovan and } \\
\text { McCune (2005), } \\
\text { Jovan (2008), } \\
\text { Fenn et al. } \\
\text { (2010), Geiser et } \\
\text { al. (2010) }\end{array}$ \\
\hline
\end{tabular}


Table 1. Continued.

\begin{tabular}{|c|c|c|c|c|c|c|}
\hline Ecoregion & $\begin{array}{l}\text { Ecosystem } \\
\text { component }\end{array}$ & $\begin{array}{c}\text { CL for N } \\
\text { deposition } \\
\left(\mathrm{kg} \mathrm{N}^{-}\right. \\
\left.\mathrm{ha}^{-1} \cdot \mathrm{yr}^{-1}\right)\end{array}$ & Reliability $\dagger$ & Response & Comments & Study \\
\hline $\begin{array}{l}\text { Mediterranean } \\
\text { California }\end{array}$ & $\begin{array}{l}\text { chaparral, oak } \\
\text { woodlands, } \\
\text { Central } \\
\text { Valley }\end{array}$ & $10-14$ & $\#$ & $\begin{array}{l}\mathrm{NO}_{3}^{-} \text {leaching, } \\
\text { stimulated } \mathrm{N} \\
\text { cycling }\end{array}$ & $\begin{array}{l}\text { CL for } \mathrm{NO}_{3}^{-} \text {leaching } \\
\text { of } 10 \mathrm{~kg} \mathrm{~N} \cdot \mathrm{ha}^{-1} \text {. } \\
\mathrm{yr}^{-1} \text { based on one } \\
\text { year of throughfall } \\
\text { data in Chamise } \\
\text { Creek and an } \\
\text { additional year of } \\
\text { throughfall data } \\
\text { from adjacent Ash } \\
\text { Mountain, both in } \\
\text { Sequoia National } \\
\text { Park }\end{array}$ & $\begin{array}{l}\text { Fenn and Poth } \\
\text { (1999), } \\
\text { Fenn et al. } \\
(2003 a, b, c, \\
\text { 2010, 2011), } \\
\text { Meixner and } \\
\text { Fenn (2004) }\end{array}$ \\
\hline $\begin{array}{l}\text { Mediterranean } \\
\text { California }\end{array}$ & $\begin{array}{l}\text { mixed-conifer } \\
\text { forest, lichens }\end{array}$ & $3.1-5.2$ & \#\# & $\begin{array}{l}\text { lichen chemistry and } \\
\text { community changes }\end{array}$ & $\begin{array}{l}\text { lowest CL based on } \\
\text { lichen tissue } \\
\text { chemistry above the } \\
\text { clean site threshold }\end{array}$ & $\begin{array}{l}\text { Fenn et al. } \\
\quad(2008,2010)\end{array}$ \\
\hline $\begin{array}{l}\text { Mediterranean } \\
\text { California }\end{array}$ & $\begin{array}{l}\text { mixed-conifer } \\
\text { forest }\end{array}$ & 17 & \# & $\begin{array}{l}\text { reduced fine-root } \\
\text { biomass }\end{array}$ & & $\begin{array}{l}\text { Grulke et al. } \\
\text { (1998), Fenn } \\
\text { et al. (2008, } \\
\text { 2010) }\end{array}$ \\
\hline $\begin{array}{l}\text { Mediterranean } \\
\text { California }\end{array}$ & $\begin{array}{l}\text { mixed-conifer } \\
\text { forest }\end{array}$ & $17-25.9$ & \# & $\begin{array}{l}\mathrm{NO}_{3}^{-} \text {leaching, soil } \\
\text { acidification }\end{array}$ & & $\begin{array}{l}\text { Breiner et al. } \\
\text { (2007), Fenn } \\
\text { et al. (2008, } \\
\text { 2010) }\end{array}$ \\
\hline $\begin{array}{l}\text { Mediterranean } \\
\text { California }\end{array}$ & $\begin{array}{l}\text { mixed-conifer } \\
\text { forest }\end{array}$ & $24-39$ & $(\#)$ & $\begin{array}{l}\text { understory } \\
\text { biodiversity; forest } \\
\text { sustainability }\end{array}$ & $\begin{array}{l}\mathrm{N} \text { deposition from } \\
\text { Fenn et al. } 2008\end{array}$ & $\begin{array}{l}\text { Grulke et al. } \\
\text { (1998, 2009), } \\
\text { Grulke and } \\
\text { Balduman } \\
\text { (1999), Jones } \\
\text { et al. (2004), } \\
\text { Allen et al. } \\
\text { (2007) }\end{array}$ \\
\hline $\begin{array}{l}\text { Mediterranean } \\
\text { California }\end{array}$ & $\begin{array}{l}\text { serpentine } \\
\text { grassland }\end{array}$ & 6 & \#\# & $\begin{array}{l}\text { annual grass invasion, } \\
\text { replacing native } \\
\text { herbs }\end{array}$ & $\begin{array}{l}\text { CL based on a local } \\
\text { roadside gradient; } \\
\text { serpentine grassland } \\
\text { site is actually west } \\
\text { of the Central } \\
\text { Valley }\end{array}$ & $\begin{array}{l}\text { Weiss (1999), } \\
\text { Fenn et al. } \\
(2010)\end{array}$ \\
\hline $\begin{array}{l}\text { Temperate } \\
\text { Sierras }\end{array}$ & lichens & $4-7$ & $(\#)$ & $\begin{array}{l}\text { epiphytic lichen } \\
\text { community change }\end{array}$ & $\begin{array}{l}\text { increase in proportion } \\
\text { of eutrophic } \\
\text { species. Estimated } \\
\text { from MWCF } \\
\text { model, response } \\
\text { threshold allows } \\
\sim 60 \% \text { eutrophs due } \\
\text { to dry, hot climate, } \\
\text { hardwood influence }\end{array}$ & $\begin{array}{l}\text { Geiser et al. } \\
\quad(2010)\end{array}$ \\
\hline $\begin{array}{l}\text { Temperate } \\
\text { Sierras }\end{array}$ & Pinus forest & 15 & \# & $\begin{array}{l}\text { elevated } \mathrm{NO}_{3}^{-} \text {in } \\
\text { stream and spring } \\
\text { waters }\end{array}$ & $\begin{array}{l}\text { data from Pinus } \\
\text { hartwegii sites in } \\
\text { the Desierto de los } \\
\text { Leones National } \\
\text { Park and Ajusco, } \\
\text { Mexico }\end{array}$ & $\begin{array}{l}\text { Fenn et al. } \\
\text { (1999, 2002), } \\
\text { Fenn and } \\
\text { Geiser (2011) }\end{array}$ \\
\hline $\begin{array}{l}\text { Tropical and } \\
\text { Subtropical } \\
\text { Humid Forests }\end{array}$ & N-rich forests & $<5-10$ & $(\#)$ & $\begin{array}{l}\mathrm{NO}_{3}{ }^{-} \text {leaching, } \mathrm{N} \\
\text { trace gas emissions }\end{array}$ & $\begin{array}{l}\text { CL for N-rich forests } \\
\text { should be lower } \\
\text { than for N-poor } \\
\text { forests based on } \\
\text { possibility of } \mathrm{N} \\
\text { losses }\end{array}$ & ND \\
\hline $\begin{array}{l}\text { Tropical and } \\
\text { Subtropical } \\
\text { Humid Forests }\end{array}$ & $\mathrm{N}$-poor forests & $5-10$ & $(\#)$ & $\begin{array}{l}\text { changes in community } \\
\text { composition, } \mathrm{NO}_{3}^{-} \\
\text {leaching, } \mathrm{N} \text { trace } \\
\text { gas emissions }\end{array}$ & $\begin{array}{l}\text { CL for N-poor forests } \\
\text { based on estimates } \\
\text { for Southeastern } \\
\text { Coastal Plain } \\
\text { forests }\end{array}$ & ND \\
\hline
\end{tabular}


TABle 1. Continued.

\begin{tabular}{|c|c|c|c|c|c|c|}
\hline Ecoregion & $\begin{array}{l}\text { Ecosystem } \\
\text { component }\end{array}$ & $\begin{array}{c}\text { CL for N } \\
\text { deposition } \\
(\mathrm{kg} \mathrm{N} \cdot \\
\left.\mathrm{ha}^{-1} \cdot \mathrm{yr}^{-1}\right)\end{array}$ & Reliability & Response & Comments & Study \\
\hline Wetlands & $\begin{array}{l}\text { freshwater } \\
\text { wetlands }\end{array}$ & $2.7-13$ & $\#$ & $\begin{array}{l}\text { peat accumulation } \\
\text { and NPP change }\end{array}$ & $\begin{array}{l}\text { CL for wetlands in } \\
\text { the northeastern } \\
\text { USA and } \\
\text { southeastern } \\
\text { Canada }\end{array}$ & $\begin{array}{l}\text { Rochefort et al. } \\
\text { (1990), Aldous } \\
\text { (2002), Vitt et } \\
\text { al. (2003), } \\
\text { Moore et al. } \\
\text { (2004) }\end{array}$ \\
\hline Wetlands & $\begin{array}{l}\text { freshwater } \\
\text { wetlands }\end{array}$ & $6.8-14$ & $(\#)$ & $\begin{array}{l}\text { pitcher plant } \\
\text { community change }\end{array}$ & $\begin{array}{l}\text { CL based on } \\
\text { northeastern } \\
\text { populations }\end{array}$ & $\begin{array}{l}\text { Gotelli and Ellison } \\
(2002,2006)\end{array}$ \\
\hline Wetlands & $\begin{array}{l}\text { intertidal } \\
\text { wetlands }\end{array}$ & $50-100$ & \#\# & loss of eelgrass & & $\begin{array}{l}\text { Latimer and Rego } \\
\text { (2010) }\end{array}$ \\
\hline Wetlands & $\begin{array}{l}\text { intertidal salt } \\
\text { marshes }\end{array}$ & $63-400$ & $(\#)$ & $\begin{array}{l}\text { changes in salt marsh } \\
\text { community } \\
\text { structure, microbial } \\
\text { activity, and } \\
\text { biogeochemistry }\end{array}$ & & $\begin{array}{l}\text { Wigand et al. } \\
\text { (2003), Caffrey } \\
\text { et al. (2007) }\end{array}$ \\
\hline Aquatic & western lakes & 2 & \#\# & $\begin{array}{l}\text { freshwater } \\
\text { eutrophication }\end{array}$ & & Baron (2006) \\
\hline Aquatic & eastern lakes & 8 & \# & $\mathrm{NO}_{3}{ }^{-}$leaching & & Aber et al. (2003) \\
\hline
\end{tabular}

Note: Key to abbreviations: ND, no data; AMF, arbuscular mycorrhizal fungi; MWCF, Marine West Coast Forests; and NPP, net primary productivity.

$\dagger$ Key: \#\#, reliable; \#, fairly reliable; (\#), expert judgment.

\$ Based on data from Greenland.

$\S$ Based on data from Finland.

- Based on data from Sweden.

|| Based on data from Canada.

\section{Lichens and bryophytes.-}

1. Background.-Lichens and bryophytes make substantial contributions to biodiversity. About 4100 lichens and 2300 bryophytes are known from North America north of Mexico: approximately one-fourth of the value for vascular plant diversity, $\sim 26600$ species (USDA, NRCS 2009).

2. Responses to N.-Lichens and bryophytes are among the most sensitive bioindicators of $\mathrm{N}$ in terrestrial ecosystems (Blett et al. 2003, Bobbink et al. 2003, Fenn et al. 2003a, 2010, Glavich and Geiser 2008). Unlike vascular plants, lichens and bryophytes lack specialized tissues to mediate the entry or loss of water and gases (e.g., waxy epidermis, guard cells, root steele). Thus, they rapidly hydrate and absorb gases, water, and dissolved nutrients during high humidity or precipitation events. However, they dehydrate to a metabolically inactive state quickly as well, making them slow growing and vulnerable to contaminant accumulation. Consequently, the implementation of lichen- or bryophytederived critical loads may prevent undesired impacts to much of the broader forest ecosystem, including biological diversity (McCune et al. 2007).

Lichens and bryophytes can play important roles in ecosystems. Species of epiphytic lichens in wet and mesic forests that are most sensitive to $\mathrm{N}$ (i.e., the large pendant and foliose species) play important ecological roles that are not duplicated by the nitrophytic (i.e., $\mathrm{N}$ tolerant) species that may replace them. Dominant regional oligotrophs (e.g., Alectoria, Bryoria, Lobaria, Ramalina, Usnea) comprise the bulk of lichen biomass in old-growth forests, contribute to nutrient cycling through $\mathrm{N}_{2}$ fixation, and are used for nesting material, essential winter forage for rodents and ungulates, and invertebrate habitat (McCune and Geiser 2009). Storage of water and atmospheric nutrients by these lichen genera and epiphytic bryophytes moderates humidity and provides a slow-release system of essential plant nutrients to the soil (Boonpragob et al. 1989, Knops et al. 1991, Pypker 2004, Cornelissen et al. 2007). In the tundra, lichens and bryophytes represent a significant portion of the biomass, and reindeer lichens are a vital link in the short arctic food chain (Kytöviita and Crittenden 2007). Mosses comprise the bulk of the biomass of the extensive boreal peatlands. In the desert, together with other microbiota, lichens and bryophytes form cryptogamic mats important to soil stabilization and fertility.

3. Critical loads.-The critical loads estimated (Pardo et al. 2011c) for lichens range from 1 to $9 \mathrm{~kg} \mathrm{~N} \cdot \mathrm{ha}^{-1} \cdot \mathrm{yr}^{-1}$ (Table 4, Fig. 4a). Although the reported range of critical loads is not as large as the ranges for forests or herbs, the certainty associated with these estimates for lichens varies considerably by ecoregion. This is partially because of differences in sampling scheme and intensity. For example, in the Pacific Northwest, lichen communities were assessed intensively across wide environmental gradients spanning low to high $\mathrm{N}$ deposition on a fine grid over time, yielding highly reliable critical $\mathrm{N}$ load estimates (Geiser and Neitlich 2007, Jovan 2008), whereas assessments in the eastern United States are more problematic due to historical and contemporary $\mathrm{S}$ 
TABLE 2. Assessment and interpretation of empirical critical loads (CL) of nutrient $\mathrm{N}$ for North American ecoregions.

\begin{tabular}{lc}
\hline \hline Ecoregion & Factors affecting the range of CL $\dagger$ \\
\hline Tundra & (1) moisture; (2) competition between \\
& vascular plants and cryptogams; (3) \\
& P-limitation; (4) temperature; (5) \\
pH
\end{tabular}

Taiga

Northern Forests

Northwestern Forested Mountains

Marine West Coast Forests

Eastern Forests

Great Plains

North American Deserts

Mediterranean California

Wetlands

Freshwaters
(1) background N status; (2) soil type; (3) species composition; (4) fire history; (5) climate

(1) soil depth; (2) vegetation type and species composition; (3) latitude

(1) receptor; (2) tree species; (3) stand age; (4) site history; (5) preexisting $\mathrm{N}$ status

(1) biotic receptor; (2) accumulated load of N; (3) ecosystem; (4) region

(1) precipitation; (2) soil cation fertility and weathering; (3) biotic receptors

(1) N status; (2) receptor; (3) precipitation

(1) receptor; (2) interaction of annual grasses with native forb cover; (3) precipitation

(1) presence of invasive exotic annual grasses interacting with a highly diverse native forb community; (2) $\mathrm{N}$ sensitivity of mycorrhizal fungi; (3) N sensitivity of lichens; (4) N retention capacity of catchments, catchment size; (5) co-occurence of ozone and ozone-sensitive tree species

(1) vegetation species; (2) the fraction of rainfall in the total water budget; (3) the degree of openness of $\mathrm{N}$ cycling

(1) extent of upstream vegetation development; (2) topographic relief; (3) land use/deposition history
Comparison within ecoregion

The CL is higher in wet and P-limited tundra; acidic tundra may be more sensitive to $\mathrm{N}$ deposition than nonacidic tundra. Increased $\mathrm{N}$ deposition may be more detrimental to lichens in the presence of graminoids and shrubs in the low and mid arctic than to lichens with less competition in the high arctic. Response time increases with latitude due to colder temperatures, less light, and poorer $\mathrm{N}$ and P mobilization.

Morphological damage to lichens has been observed at a lower deposition in forests and woodlands than in shrublands or bogs and fens; cryptogam dominated mats on thin soils become $\mathrm{N}$ saturated faster than forest islands.

CLs for lichen are generally lowest, followed by CLs for ectomycorrhizal fungi and $\mathrm{NO}_{3}{ }^{-}$leaching. CLs for herbaceous species and forests are generally higher than for other responses.

In alpine regions, diatom changes in lakes are seen at the lowest CL. Changes in individual plants are seen next, followed by vegetation community change, then soil responses.

In subalpine forests, the CL of $4 \mathrm{~kg} \mathrm{~N} \cdot \mathrm{ha}^{-1} \cdot \mathrm{yr}^{-1}$ for foliar and soil chemistry changes is similar to the lichen $C L$ of 3.1-5.2 for lichen community change.

The midrange of responses reported for lichens (2.7$\left.9.2 \mathrm{~kg} \mathrm{~N} \cdot \mathrm{ha}^{-1} \cdot \mathrm{yr}^{-1}\right)$ is broadly comparable to that for plant, soil, and mycorrhizal responses $(5 \mathrm{~kg}$ $\left.\mathrm{N} \cdot \mathrm{ha}^{-1} \cdot \mathrm{yr}^{-1}\right)$, despite limited studies for non-lichen responses.

The $\mathrm{CL}$ for $\mathrm{NO}_{3}{ }^{-}$leaching, lichen community change, and ectomycorrhizal fungal response are within the same range. Arbuscular mycorrhizal fungal and herbaceous CLs are higher.

CLs are lower in the tall grass prairie than in the mixed- and short-grass prairies. CL in tall- and mixed-grass prairie is lower on $\mathrm{N}$ poor sites and sites with very $\mathrm{N}$-responsive plant species. $\mathrm{CL}$ in the short-grass prairie is likely lower in wet years than in dry years.

The lichen CL is lowest, at $3 \mathrm{~kg} \mathrm{~N} \cdot \mathrm{ha}^{-1} \cdot \mathrm{yr}^{-1}$; vegetation CL varies from 3 to $8.4 \mathrm{~kg} \mathrm{~N} \cdot \mathrm{ha}^{-1} \cdot \mathrm{yr}^{-1}$.

The lowest CLs in Mediterranean California are for sensitive lichen in chaparral and oak woodlands and mixed conifer forests. The CL for plant and mycorrhizal fungal community change in coastal sage scrub is higher, at 7.8 to $10 \mathrm{~kg} \mathrm{~N} \cdot \mathrm{ha}^{-1} \cdot \mathrm{yr}^{-1}$. $\mathrm{CL}$ for $\mathrm{NO}_{3}{ }^{-}$leaching is lower in chaparral and oak woodlands $\left(10-14 \mathrm{~kg} \mathrm{~N} \cdot \mathrm{ha}^{-1} \cdot \mathrm{yr}^{-1}\right)$ than in mixed conifer forests $\left(17 \mathrm{~kg} \mathrm{~N} \cdot \mathrm{ha}^{-1} \cdot \mathrm{yr}^{-1}\right)$. CLs are highest for mixed conifer forest plant community change and sustainability. Fine-root biomass in ponderosa pine is reduced by both ozone and elevated soil $\mathrm{N}$.

$\mathrm{CL}$ is much higher for intertidal wetlands $(50-400 \mathrm{~kg}$ $\left.\mathrm{N} \cdot \mathrm{ha}^{-1} \cdot \mathrm{yr}^{-1}\right)$ than for freshwater wetlands $(2.7-14$ $\mathrm{kg} \mathrm{N} \cdot \mathrm{ha}^{-1} \cdot \mathrm{yr}^{-1}$ ), which have relatively closed water and $\mathrm{N}$ cycles.

CLs are lower in western mountain lakes/streams with poorly vegetated watersheds and steep catchments. CLs are greater in eastern lakes with prior land use and decades of acidic deposition.

$\dagger$ This explains what factors cause the critical load (CL) to be at the low or high end of the range reported.

$\$$ Comparison of values and causes for differences if multiple critical loads are reported for an ecoregion. 
TABLE 3. Empirical critical loads (CL) of nutrient $\mathrm{N}$ for mycorrhizal fungi in U.S. ecoregions.

\begin{tabular}{|c|c|c|c|c|c|c|}
\hline Ecoregion & $\begin{array}{l}\text { Ecosystem } \\
\quad \text { (site) }\end{array}$ & $\begin{array}{c}\text { CL for N } \\
\text { deposition } \\
(\mathrm{kg} \mathrm{N} \cdot \\
\left.\mathrm{ha}^{-1} \cdot \mathrm{yr}^{-1}\right)\end{array}$ & Reliability $\dagger$ & Response & Comments & Study \\
\hline Taiga & spruce forests & $5-7$ & $(\#)$ & $\begin{array}{l}\text { ectomycorrhizal } \\
\text { fungi, change in } \\
\text { community } \\
\text { structure }\end{array}$ & $\begin{array}{l}\text { expert judgment } \\
\text { extrapolated from } \\
\text { Marine West } \\
\text { Coast spruce and } \\
\text { northern spruce-- } \\
\text { fir forest }\end{array}$ & $\begin{array}{l}\text { Lilleskov (1999), } \\
\quad \text { Lilleskov et al. } \\
\text { (2001, 2002, 2008) }\end{array}$ \\
\hline Northern Forests & $\begin{array}{l}\text { spruce-fir forest } \\
\text { (northeastern } \\
\text { U.S. } \\
\text { deposition } \\
\text { gradient) }\end{array}$ & $5-7$ & \# & $\begin{array}{l}\text { ectomycorrhizal } \\
\text { fungi, change in } \\
\text { morphotype } \\
\text { community } \\
\text { structure }\end{array}$ & $\begin{array}{l}\text { wet deposition } \\
\text { estimated from } \\
\text { Ollinger et al. } \\
\text { (1993) model }\end{array}$ & $\begin{array}{l}\text { Lilleskov et al. } \\
\text { (2008) }\end{array}$ \\
\hline Northern Forests & $\begin{array}{l}\text { northern } \\
\text { hardwood } \\
\text { forests, sugar } \\
\text { maple } \\
\text { dominated } \\
\text { (Michigan } \\
\text { gradient) }\end{array}$ & $<12$ & $(\#)$ & $\begin{array}{l}\text { AMF, decrease in } \\
\text { abundance in } \\
\text { roots, soil, } \\
\text { community } \\
\text { change }\end{array}$ & $\begin{array}{c}\mathrm{N} \text { fertilization } \\
\text { experiment }\end{array}$ & $\begin{array}{l}\text { van Diepen et al. } \\
\text { (2007), van } \\
\text { Diepen (2008) }\end{array}$ \\
\hline $\begin{array}{l}\text { Northwestern } \\
\text { Forested } \\
\text { Mountains }\end{array}$ & $\begin{array}{l}\text { Engelmann } \\
\text { spruce forests }\end{array}$ & $5-10$ & $(\#)$ & $\begin{array}{l}\text { ectomycorrhizal } \\
\text { fungi, change in } \\
\text { community } \\
\text { structure }\end{array}$ & $\begin{array}{l}\text { expert judgment } \\
\text { extrapolated from } \\
\text { Marine West } \\
\text { Coast spruce and } \\
\text { northern spruce-- } \\
\text { fir forest }\end{array}$ & $\begin{array}{l}\text { Lilleskov (1999), } \\
\quad \text { Lilleskov et al. } \\
(2001,2002,2008)\end{array}$ \\
\hline $\begin{array}{l}\text { Marine West } \\
\text { Coast Forests }\end{array}$ & $\begin{array}{l}\text { white spruce } \\
\text { forest (Kenai } \\
\text { Peninsula, } \\
\text { Alaska) }\end{array}$ & 5 & $(\#)$ & $\begin{array}{l}\text { ectomycorrhizal } \\
\text { fungi, change in } \\
\text { community } \\
\text { structure, decrease } \\
\text { in species richness }\end{array}$ & $\begin{array}{l}\text { bulk deposition; } \\
\text { historic N } \\
\text { deposition was } \\
\text { higher but } \\
\text { unquantified; CL } \\
\text { estimated from } \\
\text { regression }\end{array}$ & $\begin{array}{l}\text { Whytemare et al. } \\
\text { (1997), Lilleskov } \\
\text { (1999), Lilleskov } \\
\text { et al. (2001, 2002) }\end{array}$ \\
\hline $\begin{array}{l}\text { Eastern } \\
\text { Temperate } \\
\text { Forests }\end{array}$ & $\begin{array}{l}\text { Southeastern } \\
\text { Coastal Plain }\end{array}$ & $5-10$ & $(\#)$ & $\begin{array}{l}\text { ectomycorrhizal } \\
\text { fungi, change in } \\
\text { community } \\
\text { structure }\end{array}$ & $\begin{array}{l}\text { from one study in } \\
\text { pine barrens plus } \\
\text { extrapolation } \\
\text { from other } \\
\text { oligotrophic } \\
\text { conifer forests }\end{array}$ & $\begin{array}{l}\text { Lilleskov et al. } \\
\text { (2001, 2002, } \\
\text { 2008), Dighton et } \\
\text { al. (2004) }\end{array}$ \\
\hline $\begin{array}{l}\text { Eastern } \\
\text { Temperate } \\
\text { Forests }\end{array}$ & $\begin{array}{l}\text { Pine Barrens } \\
\text { (New Jersey, } \\
\text { Southeastern } \\
\text { Coastal Plain) }\end{array}$ & $<8$ & $(\#)$ & $\begin{array}{l}\text { ectomycorrhizal } \\
\text { fungal } \\
\text { morphotype } \\
\text { community } \\
\text { change }\end{array}$ & $\begin{array}{l}\text { bulk deposition, } \\
\text { gradient study } \\
\text { with three sample } \\
\text { points }\end{array}$ & $\begin{array}{l}\text { Dighton et al. } \\
\text { (2004) }\end{array}$ \\
\hline $\begin{array}{l}\text { Eastern } \\
\text { Temperate } \\
\text { Forests }\end{array}$ & $\begin{array}{l}\text { eastern } \\
\text { hardwoods, } \\
\text { sugar maple } \\
\text { dominated } \\
\text { (Michigan } \\
\text { gradient) }\end{array}$ & $<12$ & $(\#)$ & $\begin{array}{l}\text { AMF; decrease in } \\
\text { abundance in } \\
\text { roots, soil, } \\
\text { community } \\
\text { change }\end{array}$ & $\begin{array}{l}\text { long-term }(12 \mathrm{yr}) \mathrm{N} \\
\text { fertilization } \\
\text { experiment in } \\
\text { sugar maple }\end{array}$ & $\begin{array}{l}\text { van Diepen et al. } \\
\text { (2007), van } \\
\text { Diepen (2008) }\end{array}$ \\
\hline Great Plains & $\begin{array}{l}\text { Chicago } \\
\text { grassland }\end{array}$ & 12 & $(\#)$ & $\begin{array}{l}\text { AMF; decrease in } \\
\% \text { colonization, } \\
\text { spore density }\end{array}$ & $\begin{array}{l}\text { CL estimated from } \\
\text { logarithmic curve } \\
\text { of soil N vs. } \\
\text { AMF activity; no } \\
\text { low N baseline, so } \\
\text { CL may be lower }\end{array}$ & $\begin{array}{l}\text { L. M. Egerton- } \\
\text { Warburton, } \\
\text { unpublished data }\end{array}$ \\
\hline $\begin{array}{l}\text { Mediterranean } \\
\text { California }\end{array}$ & $\begin{array}{l}\text { coastal sage } \\
\text { scrub } \\
\text { (southern } \\
\text { California) }\end{array}$ & $7.8-9.2$ & \# & $\begin{array}{c}\text { AMF, decrease in } \\
\% \text { colonization, } \\
\text { spore density, } \\
\text { spore richness }\end{array}$ & $\begin{array}{l}\text { CL estimated from } \\
\text { logarithmic curve } \\
\text { fitted to data } \\
\text { from this study } \\
\text { compared to } \\
\text { modeled and } \\
\text { inferential N } \\
\text { deposition data }\end{array}$ & $\begin{array}{l}\text { Egerton-Warburton } \\
\text { and Allen (2000), } \\
\text { Tonnesen et al. } \\
(2007)\end{array}$ \\
\hline
\end{tabular}

Note: AMF stands for arbuscular mycorrhizal fungi.

$\dagger$ Key: \#, fairly reliable; (\#), expert judgment. 
TABLE 4. Empirical critical loads (CL) of nutrient $\mathrm{N}$ for lichens in U.S. ecoregions.

\begin{tabular}{|c|c|c|c|c|c|c|}
\hline Ecoregion & Ecosystem (site) & $\begin{array}{c}\text { CL for N } \\
\text { deposition } \\
(\mathrm{kg} \mathrm{N} \cdot \\
\left.\mathrm{ha}^{-1} \cdot \mathrm{yr}^{-1}\right)\end{array}$ & Reliability $\dagger$ & Response & Comments & Study \\
\hline Tundra & tundra & $1-3$ & $(\#)$ & $\begin{array}{l}\text { changes in lichen } \\
\text { pigment } \\
\text { production and } \\
\text { ultrastructure, } \\
\text { changes in lichen } \\
\text { and bryophyte } \\
\text { cover }\end{array}$ & $\begin{array}{l}\mathrm{N} \text { addition studies, } \\
\text { high and low } \\
\text { arctic, } \mathrm{P} \text { enhanced } \\
\mathrm{N} \text { effects }\end{array}$ & $\begin{array}{l}\text { Hyvärinen et al. } \\
\text { (2003), } \$ \\
\text { Makkonen et al. } \\
(2007), \$ \text { Arens et } \\
\text { al. }(2008) \S\end{array}$ \\
\hline Taiga & taiga & $1-3$ & \# & $\begin{array}{l}\text { changes in alga, } \\
\text { bryophyte, and } \\
\text { lichen community } \\
\text { composition, } \\
\text { cover, tissue } \mathrm{N} \text { or } \\
\text { growth rates }\end{array}$ & $\begin{array}{l}\text { application of } \\
\text { western Oregon } \\
\text { and Washington } \\
\text { model using } \\
\text { estimated } \\
\text { response } \\
\text { thresholds }\end{array}$ & $\begin{array}{l}\text { Poikolainen et al. } \\
\text { (1998), } \$ \\
\text { Strengbom et al. } \\
\text { (2003), Vitt et al. } \\
\text { (2003), } \| \\
\text { Berryman et al. } \\
\text { (2004),\| Moore et } \\
\text { al. (2004), } \\
\text { Berryman and } \\
\text { Straker (2008), } \| \\
\text { Geiser et al. } \\
\text { (2010) }\end{array}$ \\
\hline Northern Forests & northern forests & $4-6$ & $(\#)$ & $\begin{array}{l}\text { changes in lichen } \\
\text { physiology and } \\
\text { community } \\
\text { structure }\end{array}$ & $\begin{array}{l}\text { application of } \\
\text { western Oregon } \\
\text { and Washington } \\
\text { model using } \\
\text { estimated } \\
\text { response } \\
\text { thresholds }\end{array}$ & Geiser et al. (2010) \\
\hline $\begin{array}{l}\text { Northwestern } \\
\text { Forested } \\
\text { Mountains }\end{array}$ & $\begin{array}{l}\text { coniferous } \\
\quad \text { forests, Alaska }\end{array}$ & $1.2-3.7$ & $(\#)$ & $\begin{array}{l}\text { lichen community } \\
\text { composition }\end{array}$ & $\begin{array}{l}\text { application of } \\
\text { western Oregon } \\
\text { and Washington } \\
\text { model using } \\
\text { estimated } \\
\text { response } \\
\text { thresholds }\end{array}$ & Geiser et al. (2010) \\
\hline $\begin{array}{l}\text { Northwestern } \\
\text { Forested } \\
\text { Mountains }\end{array}$ & $\begin{array}{l}\text { coniferous } \\
\text { forests, non- } \\
\text { Alaska }\end{array}$ & $2.5-7.1$ & \#\# & $\begin{array}{l}\text { lichen community } \\
\text { composition }\end{array}$ & $\begin{array}{l}\text { application of } \\
\text { western Oregon } \\
\text { and Washington } \\
\text { model }\end{array}$ & Geiser et al. (2010) \\
\hline $\begin{array}{l}\text { Northwestern } \\
\text { Forested } \\
\text { Mountains }\end{array}$ & $\begin{array}{l}\text { Central Southern } \\
\text { Sierras }\end{array}$ & $3.1-5.2$ & \#\# & $\begin{array}{l}\text { shifts in epiphytic } \\
\text { lichen } \\
\text { communities } \\
\text { favoring eutrophs }\end{array}$ & $\begin{array}{l}\text { lowest CL based on } \\
\text { exceedance of a } \mathrm{N} \\
\text { concentration } \\
\text { threshold in the } \\
\text { lichen Letharia } \\
\text { vulpina }\end{array}$ & $\begin{array}{l}\text { Fenn et al. }(2008, \\
2010)\end{array}$ \\
\hline $\begin{array}{l}\text { Marine West } \\
\text { Coast Forests }\end{array}$ & $\begin{array}{l}\text { western Oregon } \\
\text { and } \\
\text { Washington } \\
\text { forests }\end{array}$ & $2.7-9.2$ & \#\# & $\begin{array}{l}\text { shifts in epiphytic } \\
\text { lichen } \\
\text { communities } \\
\text { favoring eutrophs }\end{array}$ & $\begin{array}{l}\text { CL increases with } \\
\text { increasing mean } \\
\text { annual } \\
\text { precipitation from } \\
40 \text { to } 240 \mathrm{~cm}\end{array}$ & Geiser et al. (2010) \\
\hline Eastern Forests & $\begin{array}{l}\text { eastern } \\
\text { hardwoods } \\
\text { and } \\
\text { Southeastern } \\
\text { Coastal Plain }\end{array}$ & $4-6$ & $(\#)$ & $\begin{array}{l}\text { shifts in epiphytic } \\
\text { lichen } \\
\text { communities } \\
\text { favoring eutrophs }\end{array}$ & $\begin{array}{l}\text { application of } \\
\text { western Oregon } \\
\text { and Washington } \\
\text { model using } \\
\text { estimated } \\
\text { response } \\
\text { thresholds }\end{array}$ & Geiser et al. (2010) \\
\hline $\begin{array}{l}\text { North American } \\
\text { Deserts }\end{array}$ & $\begin{array}{l}\text { cold desert } \\
\text { (Hells Canyon } \\
\text { National } \\
\text { Resource } \\
\text { Area) }\end{array}$ & 3 & $(\#)$ & $\begin{array}{l}\text { increased cover and } \\
\text { abundance of } \\
\text { nitrophilous } \\
\text { lichens on tall } \\
\text { shrubs, increased } \\
\text { parasitism of } \\
\text { lichens }\end{array}$ & $\begin{array}{l}\text { CL estimated from } \\
\text { overlay of course } \\
\text { grid }(36 \mathrm{~km}) \\
\text { CMAQ N, local } \\
\mathrm{N} \text { deposition } \\
\text { from } \mathrm{NH}_{3} \text { was } \\
\text { likely higher }\end{array}$ & $\begin{array}{l}\text { Porter (2007), } \\
\text { Geiser et al. } \\
\text { (2008) }\end{array}$ \\
\hline
\end{tabular}


TABle 4. Continued.

\begin{tabular}{|c|c|c|c|c|c|c|}
\hline Ecoregion & Ecosystem (site) & $\begin{array}{c}\text { CL for N } \\
\text { deposition } \\
\left(\mathrm{kg} \mathrm{N}^{-}\right. \\
\left.\mathrm{ha}^{-1} \cdot \mathrm{yr}^{-1}\right)\end{array}$ & Reliability $\dagger$ & Response & Comments & Study \\
\hline $\begin{array}{l}\text { Mediterranean } \\
\text { California }\end{array}$ & $\begin{array}{l}\text { oak woodlands } \\
\text { and chaparral } \\
\text { (Central } \\
\text { Valley: } \\
\text { Sacramento } \\
\text { Valley, Coast } \\
\text { Ranges, and } \\
\text { Sierra } \\
\text { foothills) }\end{array}$ & $3-6$ & \# & $\begin{array}{l}\text { shifts in epiphytic } \\
\text { lichen } \\
\text { communities } \\
\text { favoring eutrophs }\end{array}$ & $\begin{array}{l}\text { application of } \\
\text { western Oregon } \\
\text { and Washington } \\
\text { model using } \\
\text { response } \\
\text { thresholds based } \\
\text { on FHM data }\end{array}$ & $\begin{array}{l}\text { Jovan and McCune } \\
(2005) \text {, Jovan } \\
(2008) \text {, Geiser et } \\
\text { al. (2010) }\end{array}$ \\
\hline $\begin{array}{l}\text { Mediterranean } \\
\text { California }\end{array}$ & $\begin{array}{l}\text { mixed-conifer } \\
\text { forest (Sierra } \\
\text { Nevada) }\end{array}$ & $3.1-5.2$ & \#\# & $\begin{array}{l}\text { shifts in epiphytic } \\
\text { lichen } \\
\text { communities } \\
\text { favoring eutrophs }\end{array}$ & $\begin{array}{l}\text { extrapolated from } \\
\text { Northwestern } \\
\text { Forested } \\
\text { Mountains Sierra } \\
\text { Nevada study }\end{array}$ & Fenn et al. (2008) \\
\hline Temperate Sierras & lichens & $4-7$ & $(\#)$ & $\begin{array}{l}\text { shifts in epiphytic } \\
\text { lichen } \\
\text { communities } \\
\text { favoring eutrophs }\end{array}$ & $\begin{array}{l}\text { application of } \\
\text { western Oregon } \\
\text { and Washington } \\
\text { model using } \\
\text { estimated } \\
\text { response } \\
\text { thresholds }\end{array}$ & Geiser et al. (2010) \\
\hline
\end{tabular}

Note: Abbreviations are: CMAQ, Community Multiscale Air Quality; FHM, forest health monitoring.

$\dagger$ Key: \#\#, reliable; \#, fairly reliable; (\#), expert judgment.

$\$$ Based on data from Finland.

$\S$ Based on data from Greenland.

- Based on data from Sweden.

|| Based on data from Canada.

and $\mathrm{N}$ deposition. In such cases, where historical information necessary to identify a "pristine" or "clean" state is lacking, it is more difficult to determine the critical load, and the resulting confidence associated with the critical load is low. The critical load of $\mathrm{N}$ for lichens, based on the shift in community composition favoring eutrophs over oligotrophs, is on the order of current $\mathrm{N}$ deposition, and thus is exceeded across most of the Eastern and Northern Forests ecoregions and in many areas downwind of agricultural and urban emissions or at high elevation in the West (Fig. 4b). The uncertainty associated with the exceedance, like that for the critical load, is low for the Marine West Coast Forests, Northwestern Forested Mountains ecoregions, and Mediterranean California forest, but high elsewhere.

Studies in the Pacific Northwest demonstrate that increasing precipitation allows lichens to tolerate higher N deposition (Geiser and Neitlich 2007, Jovan 2008, Geiser at al. 2010), probably because the concentrations of $\mathrm{N}$ compounds to which lichens are exposed are more important than total loading. If such simple models could be tested and confirmed in other regions of the country, the confidence in the critical loads in those regions would improve.

Herbaceous species and shrubs.-

1. Background.-Herbaceous species and shrubs (Table 5, Fig. 5) are found in grasslands, shrublands, forests, deserts, and wetlands, and comprise the majority of the roughly 26600 vascular plant species found in North America north of Mexico (USDA, NRCS 2009).

2. Response to N.-Herbaceous species and some shrubs appear intermediate between cryptogam and tree species in their sensitivity to $\mathrm{N}$ deposition (due to specialized tissues that mediate the entry or loss of water and gases compared with cryptogams) and rapid growth rates, shallow rooting systems, and often shorter life span compared with trees. Thus, herbaceous species in a forest understory will likely respond more rapidly to changes in $\mathrm{N}$ deposition and to a greater degree than the trees with which they coexist. Herbaceous species in alpine or tundra environments will respond later and to a lesser degree than the cryptogams with which they coexist. Herbaceous plants clearly play an important role in those ecosystems in which they are the dominant primary producers (e.g., grasslands, shrublands). In forests, however, the role of the herbaceous community in ecosystem function has a significance that is disproportionate to its low relative biomass. For example, although they represent only $\sim 0.2 \%$ of standing aboveground biomass, herbaceous understory species produce $>15 \%$ of forest litter biomass and comprise up to $90 \%$ of forest plant biodiversity, including endangered or threatened species (Gilliam 2007).

3. Critical loads.-The range of critical loads for $\mathrm{N}$ for herbaceous species and shrubs across all ecoregions is 3 $33 \mathrm{~kg} \mathrm{~N} \cdot \mathrm{ha}^{-1} \cdot \mathrm{yr}^{-1}$ (Table 5, Fig. 5). Although this range is broader than those for lichens or mycorrhizal fungi, many of the critical loads for herbaceous species fall into 
a
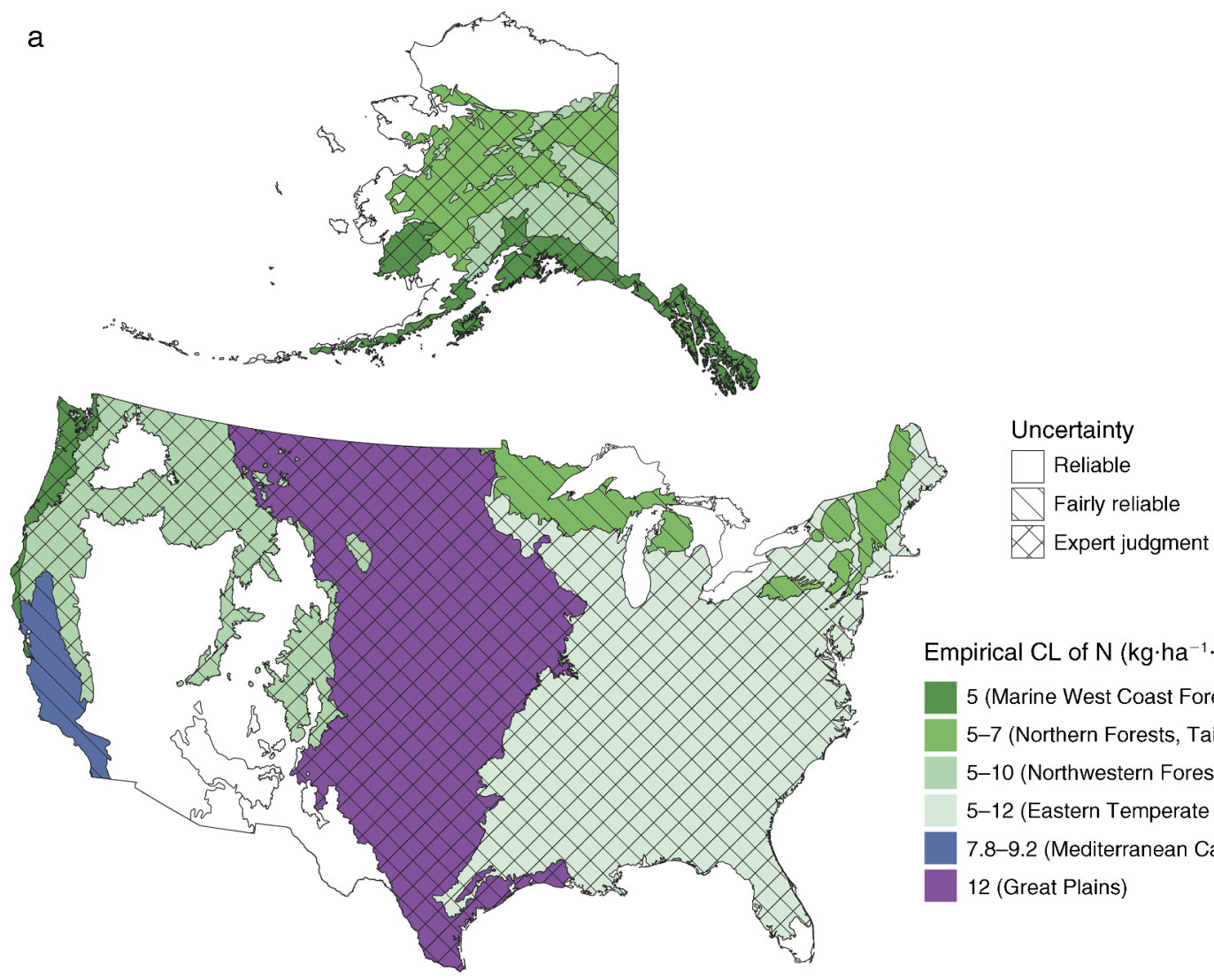

b

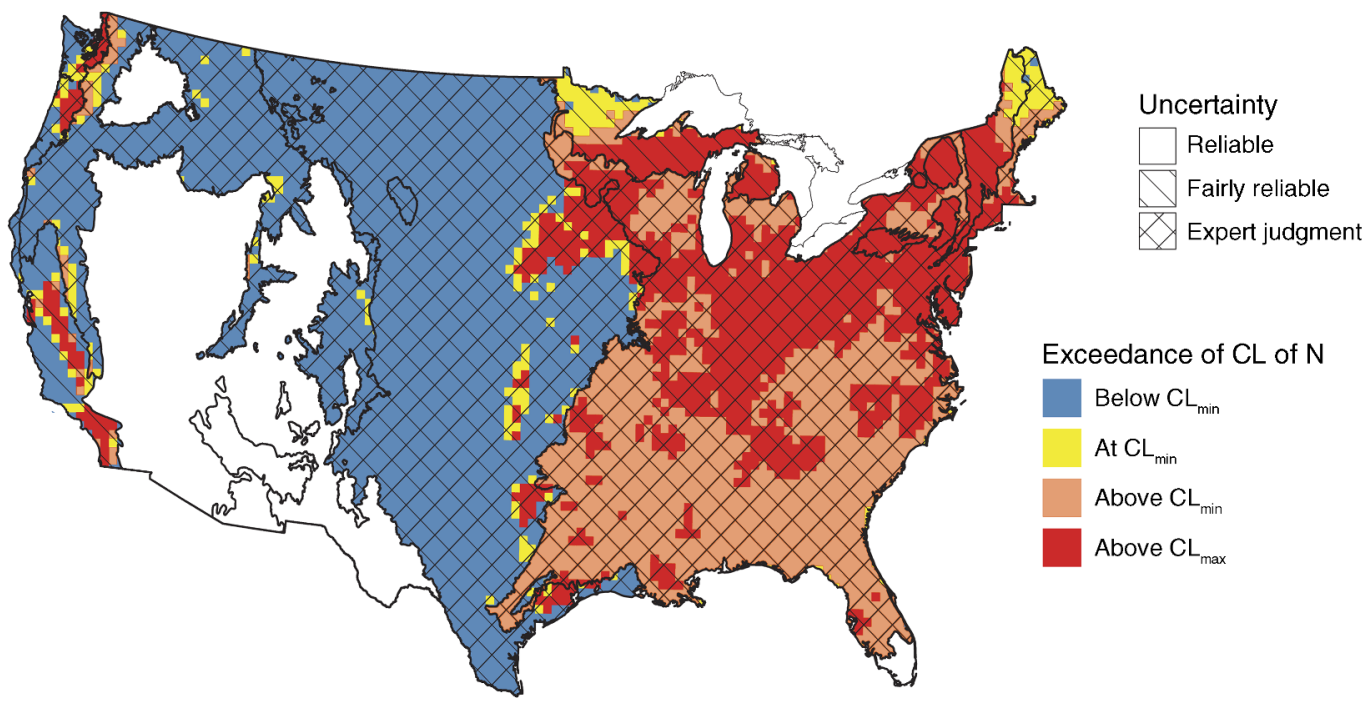

FIG. 3. Map of (a) critical loads (CL) and (b) exceedances of $\mathrm{N}$ for mycorrhizal fungi by ecoregion in the United States. (a) The range of critical loads reported for mycorrhizal fungi is shown for each ecoregion. The hatch marks indicate increasing level of uncertainty: no hatch marks for the most certain "reliable" category, single hatching for the "fairly reliable" category, and crosshatching for the "expert judgment" category. The color sequence moves from red toward blue and violet as the critical load increases. As the range of the critical load gets broader, the saturation of the color decreases. (b) Exceedance (critical load deposition) is shown for several categories: (1) no exceedance (Below $\mathrm{CL}_{\min }$ ), when deposition is lower than the CL range, (2) at $\mathrm{CL}_{\min }$, when deposition is within \pm 1 of the $\mathrm{CL}$ range, (3) above $\mathrm{CL}_{\min }$, when deposition is above the lower end of the $\mathrm{CL}$ range, but lower than the upper end of the range, (4) above $\mathrm{CL}_{\max }$, when deposition is above the upper end of the CL range. CMAQ deposition data were not available for Alaska, so we were not able to calculate exceedance for Alaska. 
a
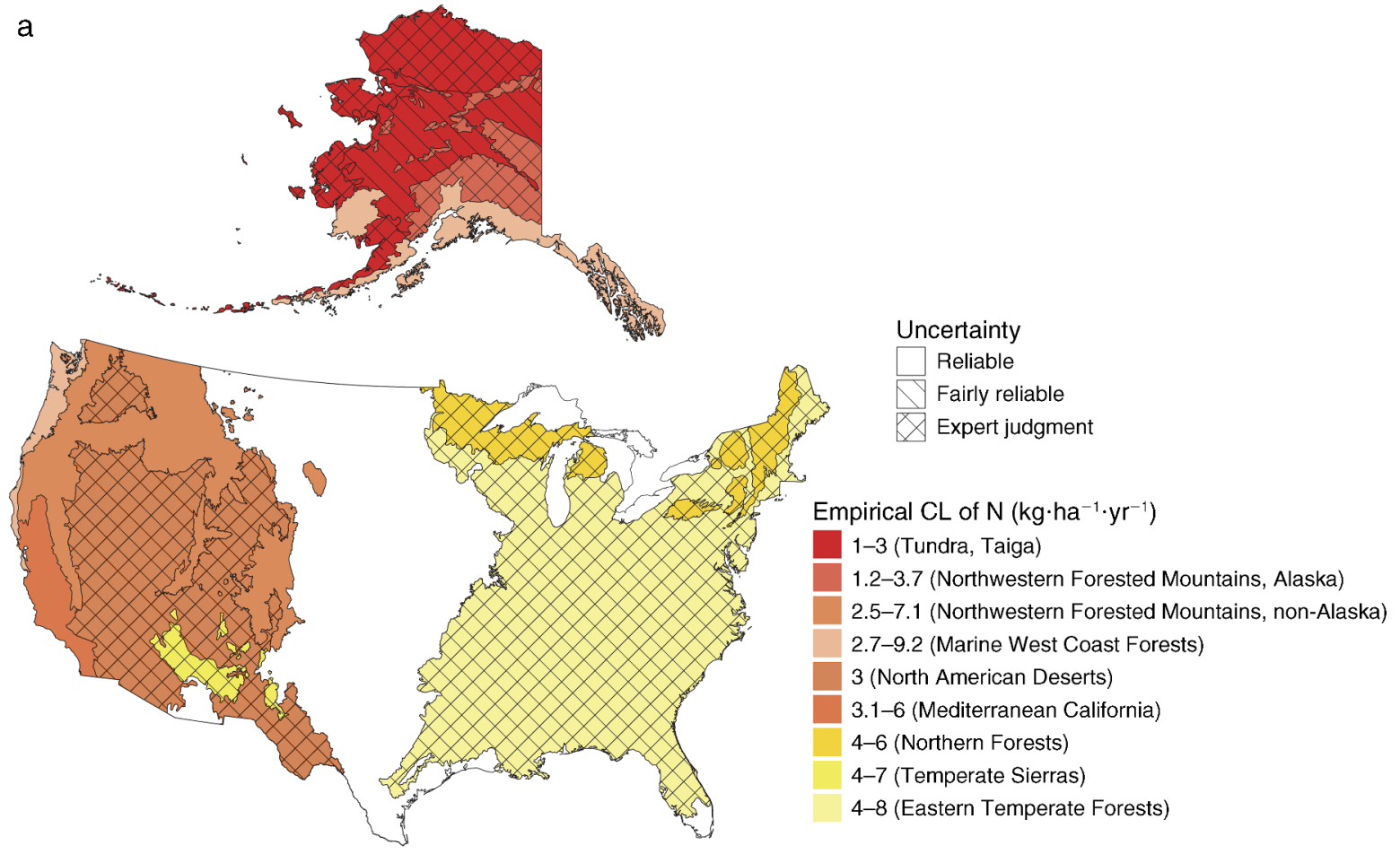

b

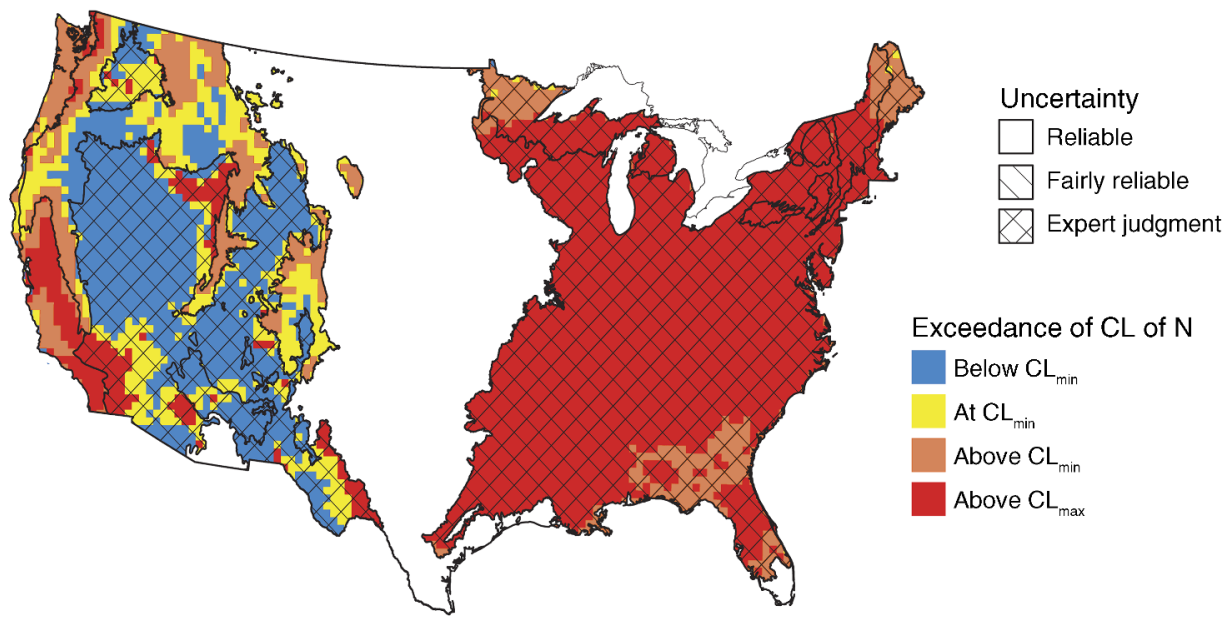

FIG. 4. Map of (a) critical loads (CL) and (b) exceedances of $N$ for lichens by ecoregion in the United States. (a) The range of critical loads reported for lichens is shown for each ecoregion. The hatch marks indicate increasing level of uncertainty: no hatch marks for the most certain "reliable" category, single hatching for the "fairly reliable" category, and cross-hatching for the "expert judgment" category. The color sequence moves from red toward blue and violet as the critical load increases. As the range of the critical load gets broader, the saturation of the color decreases. (b) Exceedance (critical load - deposition) is shown for several categories: (1) no exceedance (below $\mathrm{CL}_{\min }$ ), when deposition is lower than the $\mathrm{CL}$ range, (2) at $\mathrm{CL}_{\min }$, when deposition is within \pm 1 of the $\mathrm{CL}$ range, (3) above $\mathrm{CL}_{\min }$, when deposition is above the lower end of the CL range, but lower than the upper end of the range, (4) above $\mathrm{CL}_{\max }$, when deposition is above the upper end of the CL range. CMAQ deposition data were not available for Alaska, so we were not able to calculate exceedance for Alaska.

the range of $5-15 \mathrm{~kg} \mathrm{~N} \cdot \mathrm{ha}^{-1} \cdot \mathrm{yr}^{-1}$. The uncertainty of these estimates is moderate. The shorter life span of some herbaceous species can result in a more rapid response to $\mathrm{N}$ addition. This is especially relevant for perennials with little $\mathrm{N}$ storage or annuals. In grasslands, for example, elevated $\mathrm{N}$ deposition often leads to a rapid ( $1-10$ years) increase in herbaceous production and a shift in biomass allocation toward more aboveground tissue. This often decreases light levels at ground surface and decreases the numbers of plant species, primarily of perennials, legumes, and natives (Tilman 1993, Suding et al. 2004, Clark and Tilman 2008). 
TABLE 5. Empirical critical loads (CL) of nutrient $\mathrm{N}$ for herbaceous plants and shrubs in U.S. ecoregions.

\begin{tabular}{|c|c|c|c|c|c|c|}
\hline Ecoregion & Ecosystem (site) & $\begin{array}{c}\text { CL for N } \\
(\mathrm{kg} \mathrm{N} \cdot \\
\left.\mathrm{ha}^{-1} \cdot \mathrm{yr}^{-1}\right)\end{array}$ & Reliability† & Response & Comments & Study \\
\hline Tundra & $\begin{array}{l}\text { prostrate dwarf } \\
\text { shrub }\end{array}$ & $1-3$ & \#\# & $\begin{array}{l}\text { changes in } \mathrm{CO}_{2} \\
\text { exchange, cover, } \\
\text { foliar } \mathrm{N} \text {, and } \\
\text { community } \\
\text { composition of } \\
\text { vascular plants }\end{array}$ & $\begin{array}{l}\mathrm{N} \text { addition study, } \\
\text { Greenland high } \\
\text { arctic, } \mathrm{P} \\
\text { enhanced } \mathrm{N} \\
\text { effects }\end{array}$ & Arens et al. (2008) \\
\hline Taiga & shrublands & 6 & \#\# & $\begin{array}{l}\text { change in shrub } \\
\text { and grass cover, } \\
\text { increased } \\
\text { parasitism of } \\
\text { shrubs }\end{array}$ & $\begin{array}{l}\text { long-term, low-N } \\
\text { addition study: } \\
\text { shrub cover } \\
\text { decreased, grass } \\
\text { cover increased }\end{array}$ & $\begin{array}{l}\text { Strengbom et al. } \\
(2003) \S \text { Nordin et } \\
\text { al. }(2005) \S\end{array}$ \\
\hline Northern forests & $\begin{array}{l}\text { northern } \\
\text { hardwood } \\
\text { forests } \\
\text { (Adirondacks) }\end{array}$ & $\begin{array}{c}>7 \text { and } \\
<21\end{array}$ & \# & $\begin{array}{l}\text { alteration of } \\
\text { herbaceous } \\
\text { understory }\end{array}$ & & Hurd et al. (1998) \\
\hline $\begin{array}{l}\text { Northwestern } \\
\text { Forested } \\
\text { Mountains }\end{array}$ & alpine grasslands & $4-10$ & \#\# & $\begin{array}{l}\text { plant species } \\
\text { composition } \\
\text { change }\end{array}$ & $\begin{array}{l}\text { based on long- } \\
\text { term experiment }\end{array}$ & $\begin{array}{l}\text { Bowman et al. } \\
\quad(2006)\end{array}$ \\
\hline Eastern Forests & $\begin{array}{l}\text { eastern } \\
\text { hardwood } \\
\text { forests } \\
\text { (Fernow } \\
\text { Experimental } \\
\text { Forest, West } \\
\text { Virginia) }\end{array}$ & $<17.5$ & (\#) & $\begin{array}{l}\text { increases in } \\
\text { nitrophilic } \\
\text { species, declines } \\
\text { in species-rich } \\
\text { genera (e.g., } \\
\text { Viola) }\end{array}$ & & $\begin{array}{l}\text { Gilliam (2006, } \\
\text { 2007), Gilliam et } \\
\text { al. (2006) }\end{array}$ \\
\hline Great Plains & tallgrass prairie & $5-15$ & \# & $\begin{array}{l}\text { biogeochemical } \mathrm{N} \\
\text { cycling, plant } \\
\text { and insect } \\
\text { community } \\
\text { shifts }\end{array}$ & $\begin{array}{l}\text { long-term, low-N } \\
\text { addition study } \\
\text { that also added } \\
\text { other nutrients }\end{array}$ & $\begin{array}{l}\text { Tilman (1987, 1993), } \\
\text { Wedin and } \\
\text { Tilman (1996), } \\
\text { Clark and Tilman } \\
\text { (2008), Clark et } \\
\text { al. (2009) }\end{array}$ \\
\hline Great Plains & $\begin{array}{l}\text { mixed-grass } \\
\text { prairie }\end{array}$ & $10-25$ & \# & $\begin{array}{l}\text { soil } \mathrm{NO}_{3}^{-} \text {pools, } \\
\text { leaching, plant } \\
\text { community } \\
\text { shifts }\end{array}$ & $\begin{array}{l}\text { short-term, low-N } \\
\text { addition study }\end{array}$ & $\begin{array}{l}\text { Clark et al. (2003, } \\
\text { 2005), Jorgensen } \\
\text { et al. (2005) }\end{array}$ \\
\hline Great Plains & $\begin{array}{l}\text { short-grass } \\
\text { prairie }\end{array}$ & $10-25$ & (\#) & & $\begin{array}{l}\text { inferred from } \\
\text { mixed-grass } \\
\text { prairie }\end{array}$ & $\begin{array}{l}\text { Epstein et al. (2001) } \\
\text { Barrett and Burke } \\
(2002)\end{array}$ \\
\hline $\begin{array}{l}\text { North American } \\
\text { Desert }\end{array}$ & $\begin{array}{l}\text { warm desert } \\
\text { (Joshua Tree } \\
\text { National Park, } \\
\text { Mojave } \\
\text { Desert) }\end{array}$ & $3-8.4$ & \# & $\begin{array}{l}\text { increased biomass } \\
\text { of invasive } \\
\text { grasses; decrease } \\
\text { of native forbs }\end{array}$ & & $\begin{array}{l}\text { Allen et al. (2009), } \\
\text { Rao et al. (2010) }\end{array}$ \\
\hline $\begin{array}{l}\text { Mediterranean } \\
\text { California }\end{array}$ & $\begin{array}{l}\text { serpentine } \\
\text { grassland }\end{array}$ & 6 & \#\# & $\begin{array}{l}\text { annual grass } \\
\text { invasion, } \\
\text { replacing native } \\
\text { herbs }\end{array}$ & $\begin{array}{l}\text { CL based on a } \\
\text { local roadside } \\
\text { gradient; } \\
\text { serpentine } \\
\text { grassland site is } \\
\text { actually west of } \\
\text { the Central } \\
\text { Valley }\end{array}$ & $\begin{array}{l}\text { Weiss (1999), Fenn } \\
\text { et al. (2010) }\end{array}$ \\
\hline $\begin{array}{l}\text { Mediterranean } \\
\text { California }\end{array}$ & $\begin{array}{l}\text { coastal sage } \\
\text { scrub }\end{array}$ & $7.8-10$ & \# & $\begin{array}{l}\text { changes in invasive } \\
\text { grass cover, } \\
\text { native forb } \\
\text { richness }\end{array}$ & $\begin{array}{l}\text { modeled and } \\
\text { inferential } \mathrm{N} \\
\text { deposition } \\
\text { estimates and } \\
\text { unpublished data } \\
\text { for vegetation } \\
\text { survey }\end{array}$ & $\begin{array}{l}\text { Egerton-Warburton } \\
\text { et al. }(2001), \\
\text { Tonnesen et al. } \\
(2007), \text { Fenn et } \\
\text { al. }(2010,2011)\end{array}$ \\
\hline $\begin{array}{l}\text { Mediterranean } \\
\text { California }\end{array}$ & $\begin{array}{c}\text { mixed-conifer } \\
\text { forests (San } \\
\text { Bernardino } \\
\text { Mountains) }\end{array}$ & $24-33$ & (\#) & $\begin{array}{l}\text { changes in } \\
\text { biodiversity of } \\
\text { understory: } \\
\text { percent cover } \\
\text { and no. of } \\
\text { species } 3 \text { ha }\end{array}$ & $\begin{array}{l}\text { Based on plant } \\
\text { surveys in 1970s } \\
\text { and } 2003\end{array}$ & $\begin{array}{l}\text { Allen et al. (2007); } \\
\text { N deposition data } \\
\text { from Fenn et al. } \\
\text { (2008); M. E. } \\
\text { Fenn, unpublished } \\
\text { data }\end{array}$ \\
\hline Wetlands & $\begin{array}{l}\text { freshwater } \\
\text { wetlands }\end{array}$ & $6.8-14$ & $(\#)$ & $\begin{array}{l}\text { pitcher plant } \\
\text { community } \\
\text { change }\end{array}$ & $\begin{array}{l}\text { CL based on } \\
\text { northeastern } \\
\text { populations }\end{array}$ & $\begin{array}{l}\text { Gotelli and Ellison } \\
\quad(2002,2006)\end{array}$ \\
\hline
\end{tabular}


TABle 5. Continued.

\begin{tabular}{|c|c|c|c|c|c|c|}
\hline Ecoregion & Ecosystem (site) & $\begin{array}{c}\text { CL for N } \\
\left(\mathrm{kg} \mathrm{N}^{-}\right. \\
\left.\mathrm{ha}^{-1} \cdot \mathrm{yr}^{-1}\right)\end{array}$ & Reliability $\uparrow$ & Response & Comments & Study \\
\hline Wetlands & $\begin{array}{l}\text { intertidal } \\
\quad \text { wetlands }\end{array}$ & $50-100$ & \#\# & loss of eelgrass & & $\begin{array}{l}\text { Latimer and Rego } \\
\text { (2010) }\end{array}$ \\
\hline Wetlands & $\begin{array}{l}\text { intertidal salt } \\
\text { marsh }\end{array}$ & $63-400$ & (\#) & $\begin{array}{l}\text { changes in salt } \\
\text { marsh } \\
\text { community } \\
\text { structure, } \\
\text { microbial } \\
\text { activity and } \\
\text { biogeochemistry }\end{array}$ & & $\begin{array}{l}\text { Caffrey et al. (2007), } \\
\text { Wigand et al. } \\
\text { (2003) }\end{array}$ \\
\hline
\end{tabular}

† Key: \#\#, reliable; \#, fairly reliable; (\#), expert judgment.

$\$$ Based on data from Greenland.

$\S$ Based on data from Sweden.

As a result of this relatively rapid response, experimental studies of moderate to long duration (3-10 years) allow determination of the critical load with reasonable certainty. Longer studies ( $>10$ years) would decrease the uncertainty further. In some cases, it can be difficult to determine whether the condition in reference plots or at the low end of a deposition gradient represents a "pristine" condition or whether a site has already been altered by $\mathrm{N}$ deposition prior to or at the time of the study. For example, the Watershed Acidification Study at Fernow Experimental Forest, West Virginia, added $35 \mathrm{~kg} \mathrm{~N} \cdot \mathrm{ha}^{-1} \cdot \mathrm{yr}^{-1}$ via aerial application in addition to ambient deposition of $15-20 \mathrm{~kg} \mathrm{~N} \cdot \mathrm{ha}^{-1} \cdot \mathrm{yr}^{-1}$, which has led to changes in understory species composition (Adams et al. 2006). Recently, similar changes in understory species composition have occurred on the adjacent reference watershed receiving only ambient atmospheric deposition (Gilliam et al. 1996; F. S. Gilliam, unpublished data) suggesting that the deposition to the reference watershed currently exceeds the critical load. Where deposition rates exceed the critical load, empirical measurement of the rate of change of an ecological metric (e.g., plant abundance, diversity, or community composition) over a range of $\mathrm{N}$ inputs provides an approach to estimate the $\mathrm{N}$ level at which that metric begins to change further (Bowman et al. 2006), but it is difficult to determine the critical load.

The critical load of $\mathrm{N}$ for herbaceous species and herbs, when community change occurs (in some cases with invasives replacing native species), is exceeded across much of the Great Plains and in portions of the Southwest and in high-elevation and high-deposition areas of the other ecoregions (Fig. 5b). The uncertainty associated with the exceedance, like that for the critical load, varies.

Trees/forest ecosystems.-

1. Background.-In this section, we discuss the responses of trees and the overall biogeochemical responses of forest ecosystems to $\mathrm{N}$ inputs (Table 6), excluding the specific responses of mycorrhizal fungi, lichens, or understory herbaceous plants. Forest ecosystems represent about one-third of land cover in the
United States (USDA Forest Service 2001) and are significant in Northern, Eastern, Tropical Wet, and Marine West Coast Forests, Northwestern Forest Mountains, and Mediterranean California ecoregions.

2. Response to $N$.- In northeastern forests, gradient studies demonstrate that $\mathrm{N}$ deposition enhances growth in some fast-growing tree species, including many hardwoods with AMF associations, whereas it slows growth in some EMF species (red spruce, red pine), and has no detectable effect on still other species (Thomas et al. 2010). Similarly, N deposition enhances survivorship in a few species capable of forming AMF associations (black cherry, red maple, paper birch) and decreases survivorship in others, all ectomycorrhizal (Thomas et al. 2010). Survivorship under chronic N deposition, and possibly other co-occurring pollutants such as ozone, is often dependent on interactions with other stressors such as pests, pathogens, climate change, or drought (Grulke et al. 2009, McNulty and Boggs 2010). Over the long term, these differential effects of $\mathrm{N}$ deposition on tree growth and survivorship are likely to shift species composition, possibly to more nitrophilic species, similar to patterns seen for organisms with shorter life spans.

We have few data that show a major structural or functional shift in forest ecosystems because of the long response time of trees and forest soils to changes in $\mathrm{N}$ inputs and $\mathrm{N}$ availability (Table 6). The relatively large pools of organic $\mathrm{N}$ in the forest floor, mineral soil, tree biomass, and detritus contribute to the relatively long lag time in forest ecosystem response to $\mathrm{N}$ inputs. Because of the long lag time in response to $\mathrm{N}$ treatments, it can be difficult to determine the actual critical $\mathrm{N}$ load for forest ecosystems based on short-term fertilization studies. If a response is observed over a relatively short period of time (i.e., years), it is nearly certain that the critical load is below the total $\mathrm{N}$ input at the treatment site and it can be difficult to further constrain the critical load. It is expected that the more complex and interconnected processes in forests will result in a higher critical load than other ecosystem types, in part, because large $\mathrm{N}$ storage pools give forest ecosystems a greater capacity to buffer $\mathrm{N}$ inputs. 
3. Critical loads.-The range of critical loads reported for forest ecosystems is $4-39 \mathrm{~kg} \mathrm{~N} \cdot \mathrm{ha}^{-1} \cdot \mathrm{yr}^{-1}$ (Table 6 , Fig. 6a). The threshold $\mathrm{N}$ deposition value which caused increased $\mathrm{NO}_{3}^{-}$leaching from forest ecosystems into surface water was $8-17 \mathrm{~kg} \mathrm{~N} \cdot \mathrm{ha}^{-1} \cdot \mathrm{yr}^{-1}$; the lower end of the range representing Northern and Eastern Forests, the upper end representing Mediterranean California mixed conifers (Table 6, Fig. 7a). At $4 \mathrm{~kg} \mathrm{~N} \cdot \mathrm{ha}^{-1} \cdot \mathrm{yr}^{-1}$ in the Colorado Rockies, increasing $\left[\mathrm{NO}_{3}{ }^{-}\right]$was reported in the organic horizon, which suggests incipient $\mathrm{N}$ saturation (Rueth and Baron 2002). The highest critical loads were reported for Mediterranean California mixed-conifer forests for forest sustainability and for soil acidification caused by increased $\mathrm{N}$ deposition. These sites experience some of the highest $\mathrm{N}$ deposition reported in the United States, up to $\sim 70 \mathrm{~kg} \mathrm{~N} \cdot \mathrm{ha}^{-1} \cdot \mathrm{yr}^{-1}$ (Fenn et al. 2008).

The critical load is exceeded across much of the East. The lower end of the critical load range is exceeded for the remaining portions of the eastern forests, as well as portions of the Marine West Coast Forests, Northwestern Forested Mountains, and Tropical and Subtropical Humid Forests ecoregions (Fig. 6b).

Freshwater and wetland ecosystems.-

1. Background.-Freshwater lakes and streams, and wetlands (freshwater and estuarine intertidal) are ecosystem types that occur in most ecoregions in North America. In freshwater lakes and streams, phytoplankton, or algae that live in the water column, are sensitive to the chemical environment in which they reside, and many species can be used as indicators of the levels of nutrients or acidity because of individual species' preference for specific chemical conditions. Diatoms are used in this discussion because there has been more work published on these algae than others, but other types of algae also respond to $\mathrm{N}$ deposition (Lafrancois et al. 2004, Michel et al. 2006). Of the wetlands which occur in the conterminous United States, 95\% are freshwater and 5\% are estuarine or marine (USDI FWS 2005). The species composition differs between freshwater and intertidal wetlands, although together they support $>4200$ native plant species. Despite the high biodiversity, the effects of $\mathrm{N}$ loading are studied in just a few plant species.

2. Response to N.-For the analysis of nutrient $\mathrm{N}$ effects to freshwater lakes and streams, we relied on papers and studies that linked aquatic biological and ecological response to atmospheric deposition, but the results are consistent with laboratory or in situ dose response studies and even land use change studies. The productivity of minimally disturbed aquatic ecosystems is often limited by the availability of $\mathrm{N}$, and slight increases in available $\mathrm{N}$ trigger a rapid biological response that increases productivity and rearranges algal species assemblages (Nydick et al. 2004, Saros et al. 2005). The mechanism for change is alteration of $\mathrm{N}: \mathrm{P}$ ratios, which can increase productivity of some species at the expense of others (Elser et al. 2009). As with the terrestrial systems, the nutrient responses of lakes and streams are most evident where land use change and acidic deposition have been limited; thus, most evidence of exceedance of critical loads comes from high elevations of the western United States (Baron et al. 2011). As with terrestrial plants, some diatoms respond rapidly to an increase in available N. An example that has been observed from a number of different lakes of the Rocky Mountains is dominance of two diatoms (Asterionella formosa and Fragilaria crotonensis) in lakes with higher $\mathrm{N}$, in contrast to the flora of lakes with lower $\mathrm{N}$ deposition, where there is a more even distribution, and thus high biodiversity, of diatoms. Higher trophic levels (zooplankton, macroinvertebrates) may be secondarily affected by $\mathrm{N}$, but further increases in primary, or autotrophic, production will be limited by other nutrients such as $\mathrm{P}$ or silica $(\mathrm{Si})$.

Both freshwater and estuarine intertidal wetlands tend to be N-limited ecosystems (U.S. EPA 1993, LeBauer and Treseder 2008). Known responses to $\mathrm{N}$ enrichment are generally derived from nutrient addition studies in the field and observations along gradients of $\mathrm{N}$ deposition. A variety of ecological endpoints are evaluated, such as altered soil biogeochemistry, increased peat accumulation, elevated primary production, changes in plant morphology, changes in plant population dynamics, and altered plant species composition (U.S. EPA 2008). In general, the sensitivity of wetland ecosystems to $\mathrm{N}$ is related to the fraction of rainfall (a proxy for atmospheric $\mathrm{N}$ deposition) in the total water budget. Most freshwater wetlands, such as bogs, fens, marshes, and swamps, have relatively closed water and $\mathrm{N}$ cycles, and thus, are more sensitive to $\mathrm{N}$ deposition than intertidal estuarine wetlands, such as salt marshes and eelgrass beds (Greaver et al. 2011).

3. Critical loads.-In general, critical loads for freshwater lakes and streams tend to be low, because the target organisms are unicellular algae that respond rapidly to changes in their chemical environment. The range of critical loads for eutrophication and acidity in freshwater is 2-9 $\mathrm{kg} \mathrm{N} \cdot \mathrm{ha}^{-1} \cdot \mathrm{yr}^{-1}$ (Baron et al. 2011); the range reported for terrestrial ecosystems is much broader (Table 1). Critical loads for $\mathrm{NO}_{3}{ }^{-}$leaching from terrestrial ecosystems ranged from 4 to $17 \mathrm{~kg}$ $\mathrm{N} \cdot \mathrm{ha}^{-1} \cdot \mathrm{yr}^{-1}$ (Fig. 7a), but many sensitive freshwaters at high altitudes are found above the treeline where few watershed buffering mechanisms exist due to sparse vegetation, poorly developed soils, short hydraulic residence time, and steep topography. These factors influence how rapidly a system exhibits elevated $\mathrm{N}$ leaching in response to increased $\mathrm{N}$ deposition, and how this increased $\mathrm{N}$ availability subsequently influences biota. In general, lakes have relatively rapid $\mathrm{N}$ turnover times compared to soil $\mathrm{N}$ pools and are at least seasonally well mixed. They would, thus, be expected to have lower critical loads. Thus, responses by terrestrial plants would not be expected to be as rapid as those of freshwater organisms. The critical load for 


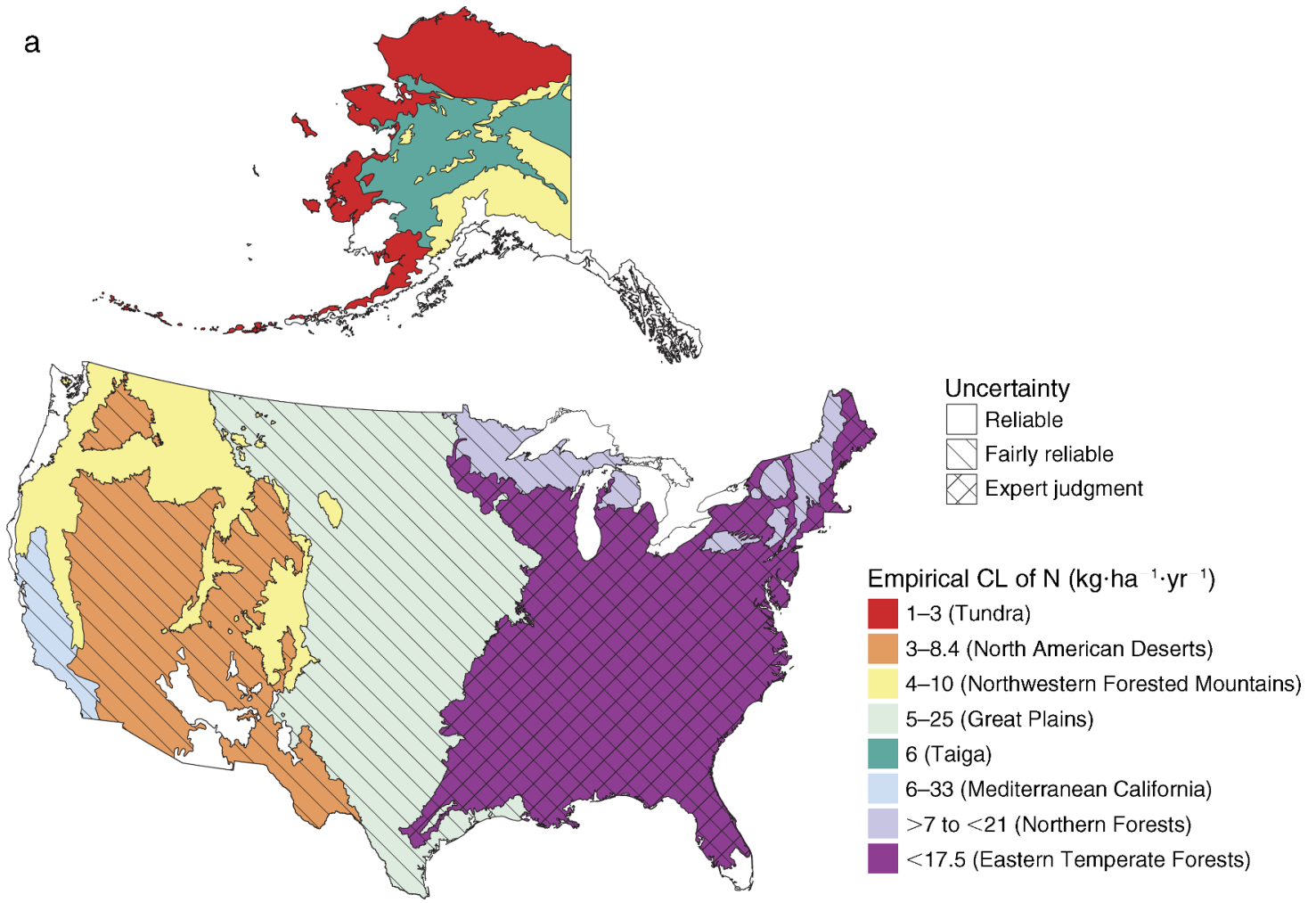

b

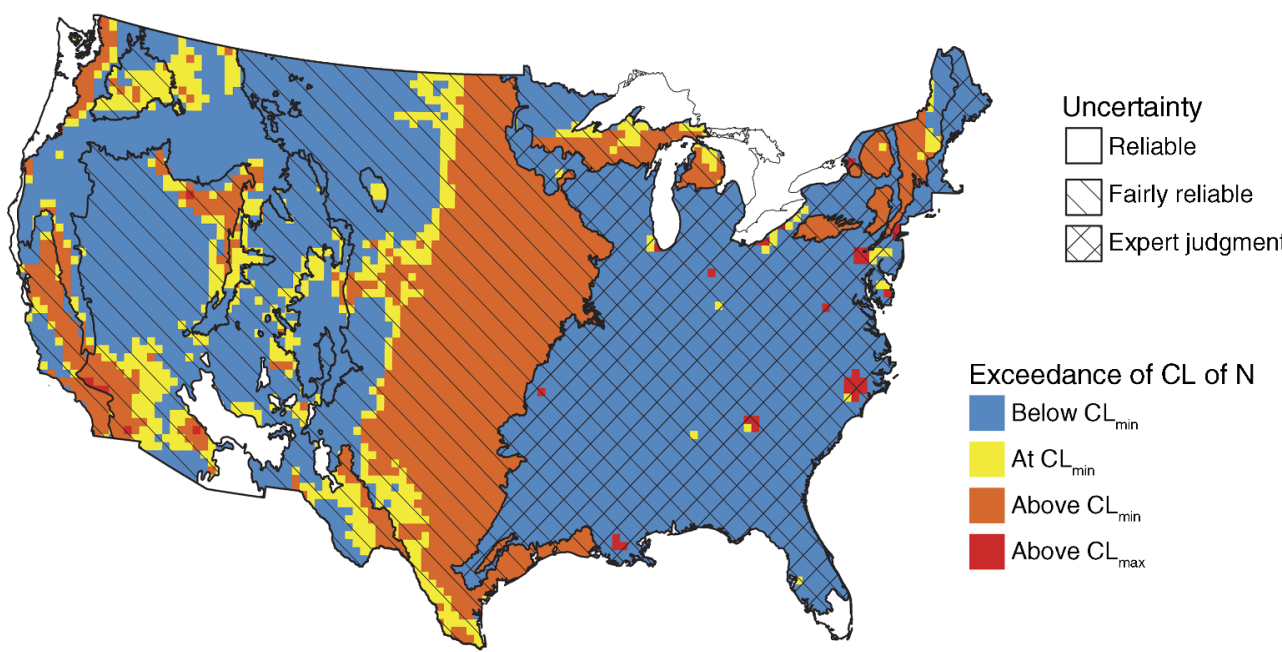

FIG. 5. Map of (a) critical loads and (b) exceedances of $\mathrm{N}$ for herbaceous plants and shrubs by ecoregion in the United States. (a) The range of critical loads reported for herbaceous plants and shrubs is shown for each ecoregion. The hatch marks indicate increasing level of uncertainty: no hatch marks for the most certain "reliable" category, single hatching for the "fairly reliable" category, and cross-hatching for the "expert judgment" category. The color sequence moves from red toward blue and violet as the critical load increases. As the range of the critical load gets broader, the saturation of the color decreases. (b) Exceedance (critical load - deposition) is shown for several categories: (1) no exceedance (below $\mathrm{CL}_{\text {min }}$ ), when deposition is lower than the $\mathrm{CL}$ range, (2) at $\mathrm{CL}_{\min }$, when deposition is within \pm 1 of the $\mathrm{CL}$ range, (3) above $\mathrm{CL}_{\min }$, when deposition is above the lower end of the $\mathrm{CL}$ range, but lower than the upper end of the range, (4) above $\mathrm{CL}_{\max }$, when deposition is above the upper end of the CL range. CMAQ deposition data were not available for Alaska, so we were not able to calculate exceedance for Alaska.

$\mathrm{NO}_{3}{ }^{-}$leaching is exceeded in portions of the Mediterranean California, and the lower end of the critical load range is exceeded for most of the Eastern Forest and part of the Great Plains ecoregions (Fig. 7b).
Generally, freshwater wetlands are more sensitive to $\mathrm{N}$ deposition than estuarine intertidal wetlands, with critical loads for freshwater wetlands that range from 2.7 to $14 \mathrm{~kg} \mathrm{~N} \cdot \mathrm{ha}^{-1} \cdot \mathrm{yr}^{-1}$ (Greaver et al. 2011). The 
TABLE 6. Empirical critical loads (CL) of nutrient $\mathrm{N}$ for forest ecosystems in U.S. ecoregions.

\begin{tabular}{|c|c|c|c|c|c|c|}
\hline Ecoregion & Ecosystem (site) & $\begin{array}{c}\mathrm{CL} \text { for N } \\
(\mathrm{kg} \mathrm{N} \cdot \\
\left.\mathrm{ha}^{-1} \cdot \mathrm{yr}^{-1}\right)\end{array}$ & Reliability $\dagger$ & Response & Comments & Study \\
\hline $\begin{array}{l}\text { Northern } \\
\text { Forests }\end{array}$ & $\begin{array}{l}\text { northeastern } \\
\text { gradient }\end{array}$ & $>3$ & $\#$ & $\begin{array}{l}\text { decline in } \\
\text { survivorship of } \\
\text { sensitive species }\end{array}$ & $\begin{array}{l}\text { based on study of } \\
\text { gradient of } \mathrm{N} \\
\text { deposition from } 3 \text { to } \\
11 \mathrm{~kg} \mathrm{~N} \cdot \mathrm{ha}^{-1} \cdot \mathrm{yr}^{-1}\end{array}$ & Thomas et al. (2010) \\
\hline $\begin{array}{l}\text { Northern } \\
\text { Forests }\end{array}$ & $\begin{array}{l}\text { hardwood and } \\
\text { coniferous } \\
\text { forests }\end{array}$ & 8 & \#\# & $\begin{array}{l}\text { increased surface } \\
\text { water and } \mathrm{NO}_{3}^{-} \\
\text {leaching }\end{array}$ & & Aber et al. (2003) \\
\hline $\begin{array}{l}\text { Northern } \\
\text { Forests }\end{array}$ & $\begin{array}{l}\text { montane spruce } \\
\text { fir (Mt. } \\
\text { Ascutney, } \\
\text { Vermont) }\end{array}$ & $\begin{array}{l}>10 \text { and } \\
<26\end{array}$ & \# & $\begin{array}{l}\text { declines in growth } \\
\text { and increased } \\
\text { mortality }\end{array}$ & & $\begin{array}{l}\text { McNulty et al. } \\
(2005)\end{array}$ \\
\hline $\begin{array}{l}\text { Northwestern } \\
\text { Forested } \\
\text { Mountains }\end{array}$ & subalpine forest & 4 & \#\# & $\begin{array}{l}\text { soil organic } \\
\text { horizon and } \\
\text { foliar N } \\
\text { enrichment and } \\
\text { higher potential } \\
\text { net } \mathrm{N} \\
\text { mineralization } \\
\text { rates }\end{array}$ & & $\begin{array}{l}\text { Baron et al. (1994), } \\
\text { Rueth and Baron } \\
\text { (2002) }\end{array}$ \\
\hline $\begin{array}{l}\text { Northwestern } \\
\text { Forested } \\
\text { Mountains }\end{array}$ & $\begin{array}{l}\text { mixed-conifer } \\
\text { forest }\end{array}$ & 17 & $\begin{array}{c}\# \# \\
\#\end{array}$ & $\begin{array}{l}\mathrm{NO}_{3}^{-} \text {leaching, } \\
\text { reduced fine- } \\
\text { root biomass }\end{array}$ & $\begin{array}{l}\text { co-occurring ozone } \\
\text { also affects fine-root } \\
\text { biomass in } \\
\text { ponderosa pine }\end{array}$ & Fenn et al. (2008) \\
\hline $\begin{array}{l}\text { Marine West } \\
\text { Coast Forests }\end{array}$ & $\begin{array}{l}\text { coastal white } \\
\text { spruce forest } \\
\text { (south-central } \\
\text { Alaska) }\end{array}$ & 5 & (\#) & $\begin{array}{l}\text { declines in tree } \\
\text { health; changes } \\
\text { in understory } \\
\text { composition; } \\
\text { foliar nutritional } \\
\text { imbalances; } \\
\text { elevated } \mathrm{NO}_{3}^{-} \\
\text {in forest floor } \\
\text { and mineral soil }\end{array}$ & & $\begin{array}{l}\text { Whytemare et al. } \\
\text { (1997), Lilleskov } \\
\text { (1999), Lilleskov } \\
\text { et al. (2001, 2002) }\end{array}$ \\
\hline Eastern Forests & $\begin{array}{l}\text { eastern } \\
\text { hardwood } \\
\text { forests }\end{array}$ & $>3$ & \# & $\begin{array}{l}\text { decline in } \\
\text { survivorship of } \\
\text { sensitive species }\end{array}$ & $\begin{array}{l}\text { based on study of } \\
\text { gradient of } \mathrm{N} \\
\text { deposition from } 3 \text { to } \\
11 \mathrm{~kg} \mathrm{~N} \cdot \mathrm{ha}^{-1} \cdot \mathrm{yr}^{-1}\end{array}$ & Thomas et al. (2010) \\
\hline Eastern Forests & $\begin{array}{l}\text { eastern } \\
\text { hardwood } \\
\text { forests }\end{array}$ & 8 & \#\# & $\begin{array}{l}\text { increased surface } \\
\text { water loading of } \\
\mathrm{NO}_{3}^{-}\end{array}$ & & Aber et al. (2003) \\
\hline $\begin{array}{l}\text { Mediterranean } \\
\text { California }\end{array}$ & $\begin{array}{l}\text { mixed-conifer } \\
\text { forests (San } \\
\text { Bernardino } \\
\text { Mountains } \\
\text { and southern } \\
\text { Sierra Nevada } \\
\text { range) }\end{array}$ & 17 & \#\# & $\begin{array}{l}\text { streamwater } \\
\quad\left[\mathrm{NO}_{3}{ }^{-}\right]>14 \\
\mu \mathrm{M}\end{array}$ & $\begin{array}{l}\text { based on regression of } \\
\text { throughfall vs. peak } \\
\text { streamwater } \mathrm{NO}_{3}^{-} \\
\text {concentrations. } \\
\text { Daycent simulations } \\
\text { gave similar results }\end{array}$ & Fenn et al. (2008) \\
\hline $\begin{array}{l}\text { Mediterranean } \\
\text { California }\end{array}$ & $\begin{array}{c}\text { mixed-conifer } \\
\text { forests (San } \\
\text { Bernardino } \\
\text { Mountains) }\end{array}$ & 17 & \# & $\begin{array}{l}\text { reduced fine-root } \\
\text { biomass }\end{array}$ & $\begin{array}{l}\text { based on regression of } \\
\text { throughfall } \mathrm{N} \\
\text { deposition and fine- } \\
\text { root biomass in } \\
\text { ponderosa pine (also } \\
\text { affected by co- } \\
\text { occurring ozone) }\end{array}$ & $\begin{array}{l}\text { Grulke et al. (1998), } \\
\text { Fenn et al. (2008) }\end{array}$ \\
\hline $\begin{array}{l}\text { Mediterranean } \\
\text { California }\end{array}$ & $\begin{array}{c}\text { mixed-conifer } \\
\text { forests (San } \\
\text { Bernardino } \\
\text { Mountains) }\end{array}$ & 25.9 & \# & $\begin{array}{l}\text { soil acidification; } \\
\qquad \mathrm{pH} \leq 4.6\end{array}$ & $\begin{array}{l}\text { based on regression of } \\
\text { throughfall } \mathrm{N} \\
\text { deposition and } \\
\text { mineral soil } \mathrm{H}+\end{array}$ & Breiner et al. (2007) \\
\hline $\begin{array}{l}\text { Mediterranean } \\
\text { California }\end{array}$ & $\begin{array}{c}\text { mixed-conifer } \\
\text { forests (San } \\
\text { Bernardino } \\
\text { Mountains) }\end{array}$ & 39 & $(\#)$ & $\begin{array}{l}\text { reduced forest } \\
\text { sustainability }\end{array}$ & $\begin{array}{l}\text { based on shifts in plant } \\
\text { phenology and C } \\
\text { allocation; caused by } \\
\text { combined effects of } \\
\text { ozone and N } \\
\text { deposition; leads to } \\
\text { increased bark beetle } \\
\text { mortality and } \\
\text { wildfire risk }\end{array}$ & $\begin{array}{l}\text { Grulke et al. (1998, } \\
\text { 2009), Grulke and } \\
\text { Balduman (1999), } \\
\text { Jones et al. } \\
\text { (2004); N } \\
\text { deposition data } \\
\text { from Fenn et al. } \\
\text { (2008) }\end{array}$ \\
\hline
\end{tabular}


TABle 6. Continued.

\begin{tabular}{|c|c|c|c|c|c|c|}
\hline Ecoregion & Ecosystem (site) & $\begin{array}{c}\mathrm{CL} \text { for N } \\
(\mathrm{kg} \mathrm{N} \cdot \\
\left.\mathrm{ha}^{-1} \cdot \mathrm{yr}^{-1}\right)\end{array}$ & Reliability $\dagger$ & Response & Comments & Study \\
\hline $\begin{array}{l}\text { Tropical and } \\
\text { Subtropical } \\
\text { Humid } \\
\text { Forests }\end{array}$ & $\begin{array}{l}\text { N-poor tropical } \\
\text { and } \\
\text { subtropical } \\
\text { forests }\end{array}$ & $5-10$ & $(\#)$ & ND & $\begin{array}{l}\text { CL for N-poor forests } \\
\text { based on estimates } \\
\text { for Southeastern } \\
\text { Coastal Plain forests }\end{array}$ & ND \\
\hline $\begin{array}{l}\text { Tropical and } \\
\text { Subtropical } \\
\text { Humid } \\
\text { Forests }\end{array}$ & $\begin{array}{l}\text { N-rich tropical } \\
\text { and } \\
\text { subtropical } \\
\text { forests }\end{array}$ & $<5-10$ & (\#) & ND & $\begin{array}{l}\text { CL for N-rich forests } \\
\text { should be lower than } \\
\text { for N-poor forests } \\
\text { based on possibility } \\
\text { of N losses }\end{array}$ & ND \\
\hline
\end{tabular}

Note: ND stands for "no data."

$\dagger$ Key: \#\#, reliable; \#, fairly reliable; (\#), expert judgment.

bryophyte genus Sphagnum and the carnivorous pitcher plant are the two taxa most commonly studied. The critical loads reported for freshwater wetlands (Greaver et al. 2011) fall between those reported for inland surface waters (Baron et al. 2011) and those reported for terrestrial ecosystems (Pardo et al. 2011a). This pattern may be related to the rate of $\mathrm{N}$ released by soils/ sediment to the ecosystem. The critical load tends to be higher for estuarine intertidal wetlands than other types of ecosystems because they have open nutrient cycles that are often strongly affected by $\mathrm{N}$ loading sources other than atmospheric deposition. Based on field observations of $\mathrm{N}$ loading effects on plant growth and species composition on salt marsh and eelgrass habitat, the critical load for estuarine intertidal wetlands ranges between 50 and $400 \mathrm{~kg} \mathrm{~N} \cdot \mathrm{ha}^{-1} \cdot \mathrm{yr}^{-1}$.

\section{Relative sensitivities of different receptors, ecosystem types, and regions}

This synthesis demonstrates that empirical critical loads for $\mathrm{N}$ differ among life-forms, tending to increase in the following sequence: diatoms $<$ lichens and bryophytes $<$ mycorrhizal fungi $<$ herbaceous plants and shrubs $<$ trees. This variation likely reflects a variety of factors, including generation time and buffering against $\mathrm{N}$ impacts. That is, $\mathrm{N}$ deposition more rapidly affects those species that experience the most direct exposure to elevated $\mathrm{N}$ levels in the atmosphere (lichens and bryophytes) or receiving waters (diatoms), especially for those organisms that lack protective structures, such as a cuticle, for example. By contrast, the capacity of soil organic matter to accumulate large quantities of $\mathrm{N}$ may delay adverse impacts on many herbs, shrubs, and trees. The effects of altered $\mathrm{N}$ availability in shifting species composition often appears to occur most rapidly within those communities dominated by species with short life spans (diatoms) compared to those with long life spans (trees).

Critical loads vary more by receptor and response type than by region. For the same response of a given receptor, the western United States has generally similar critical load values to the eastern United States, with the apparent exception that the critical load for $\mathrm{NO}_{3}{ }^{-}$ leaching is approximately twice as high in Mediterra- nean California mixed conifers compared to northeastern forests (Fig. 7). In contrast, the critical load for $\mathrm{NO}_{3}{ }^{-}$leaching in high elevation catchments in the Colorado Front Range are lowest in the United States, likely attributable to low biological $\mathrm{N}$ retention and storage capacity in these steep, rocky catchments (Baron et al. 2000, Williams and Tonnessen 2000, Sickman et al. 2002, Fenn et al. 2003a, b).

In setting critical loads, ideally one would identify an indicator that would allow prediction of future deterioration in ecosystem structure or function before it occurs: an early indicator of ecosystem change. We are not yet able to definitively determine which early responses to $\mathrm{N}$ deposition are the best indicators of ecological harm, the central criterion for setting a critical load. In some cases, alteration of community composition for a given taxa group (e.g., lichens), may signal the beginning of a cascade of changes in ecosystem $\mathrm{N}$ cycling, which may dramatically alter the structure or function of the ecosystem as a whole. In many cases, changes in a single taxa group may have implications beyond that taxa group. In other cases, alterations within the community of a given taxa group may have little impact on the overall structure and function of the ecosystem. It can be difficult to know, at the outset, whether the ultimate consequences of changes indicated by alterations to a given taxa group will be large or small for the overall ecosystem over the long term.

However, understanding of the progressive series of changes that occur during $\mathrm{N}$ saturation should inform this process, along with recognition of the role of $\mathrm{N}$ in increasing vulnerability to other stressors such as insects, drought, freezing, and other pollutants. For example, elevated $\mathrm{N}$ inputs may lead to plant nutrient imbalances, which then increase plant susceptibility to stressors such as cold, drought, or pests (Bobbink et al. 1998, Schaberg et al. 2002). These responses have been observed in a southern Vermont montane red spruce stand, where low-level $\mathrm{N}$ additions led to increased foliar $\mathrm{N}$ concentration, decreased foliar membrane-associated calcium and cold tolerance and increased winter injury (Schaberg et al. 2002). Another key indicator is increased soil $\mathrm{NO}_{3}{ }^{-}$ leaching, especially during episodic acidification of 
a
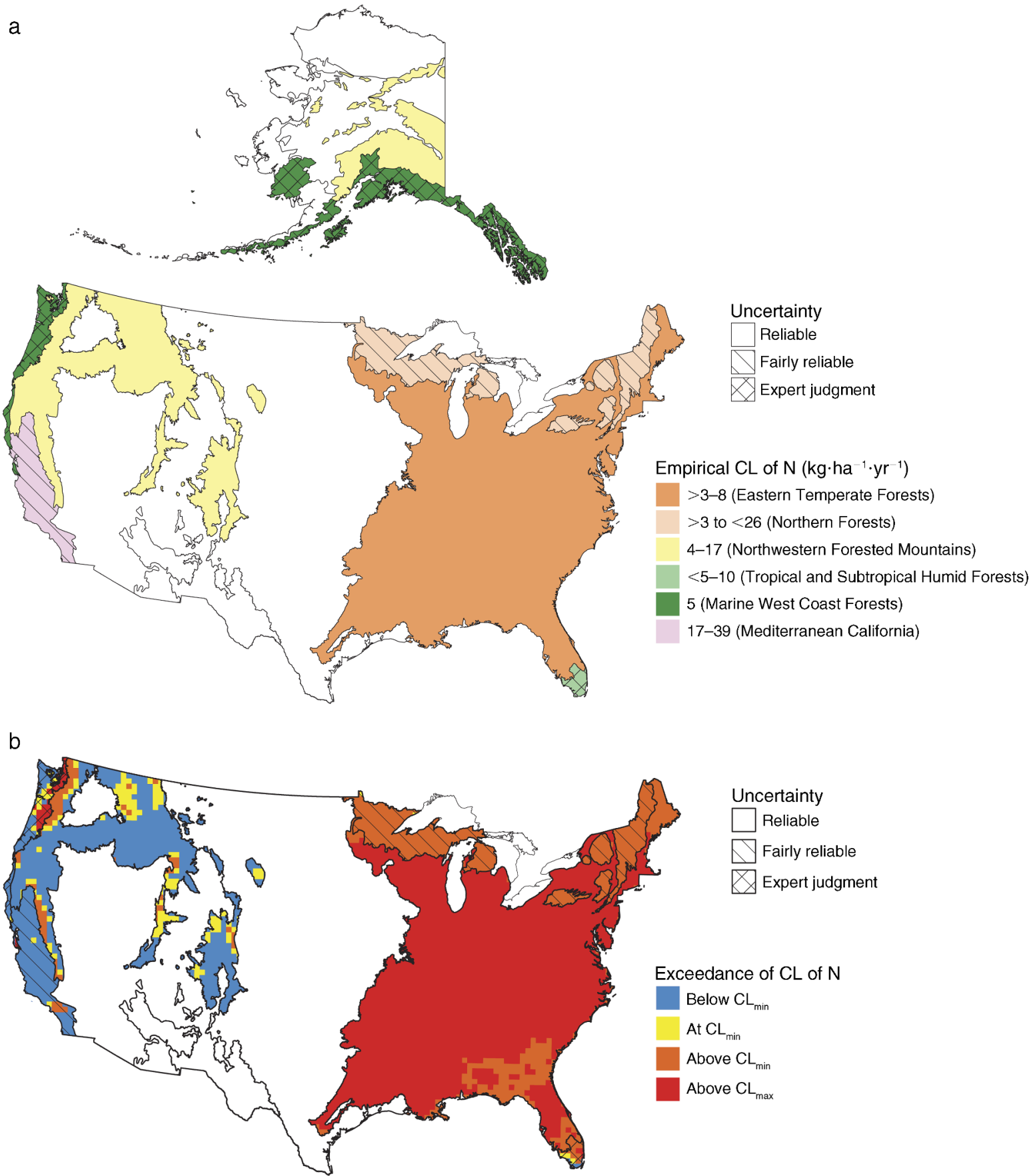

FIG. 6. Map of (a) critical loads and (b) exceedances of $\mathrm{N}$ for forest ecosystems by ecoregion in the United States. (a) The range of critical loads reported for forest ecosystems is shown for each ecoregion; this map does not include the responses of mycorrhizal fungi, lichens, or understory herbaceous plants already represented. The hatch marks indicate increasing level of uncertainty: no hatch marks for the most certain "reliable" category, single hatching for the "fairly reliable" category, and cross-hatching for the "expert judgment" category. The color sequence moves from red toward blue and violet as the critical load increases. As the range of the critical load gets broader, the saturation of the color decreases. (b) Exceedance (critical load - deposition) is shown for several categories: (1) no exceedance (below $\mathrm{CL}_{\min }$ ), when deposition is lower than the $\mathrm{CL}$ range, (2) at $\mathrm{CL}_{\min }$, when deposition is within \pm 1 of the $C L$ range, (3) above $\mathrm{CL}_{\min }$, when deposition is above the lower end of the CL range, but lower than the upper end of the range, (4) above $\mathrm{CL}_{\max }$, when deposition is above the upper end of the $\mathrm{CL}$ range. CMAQ deposition data were not available for Alaska, so we were not able to calculate exceedance for Alaska. 
a
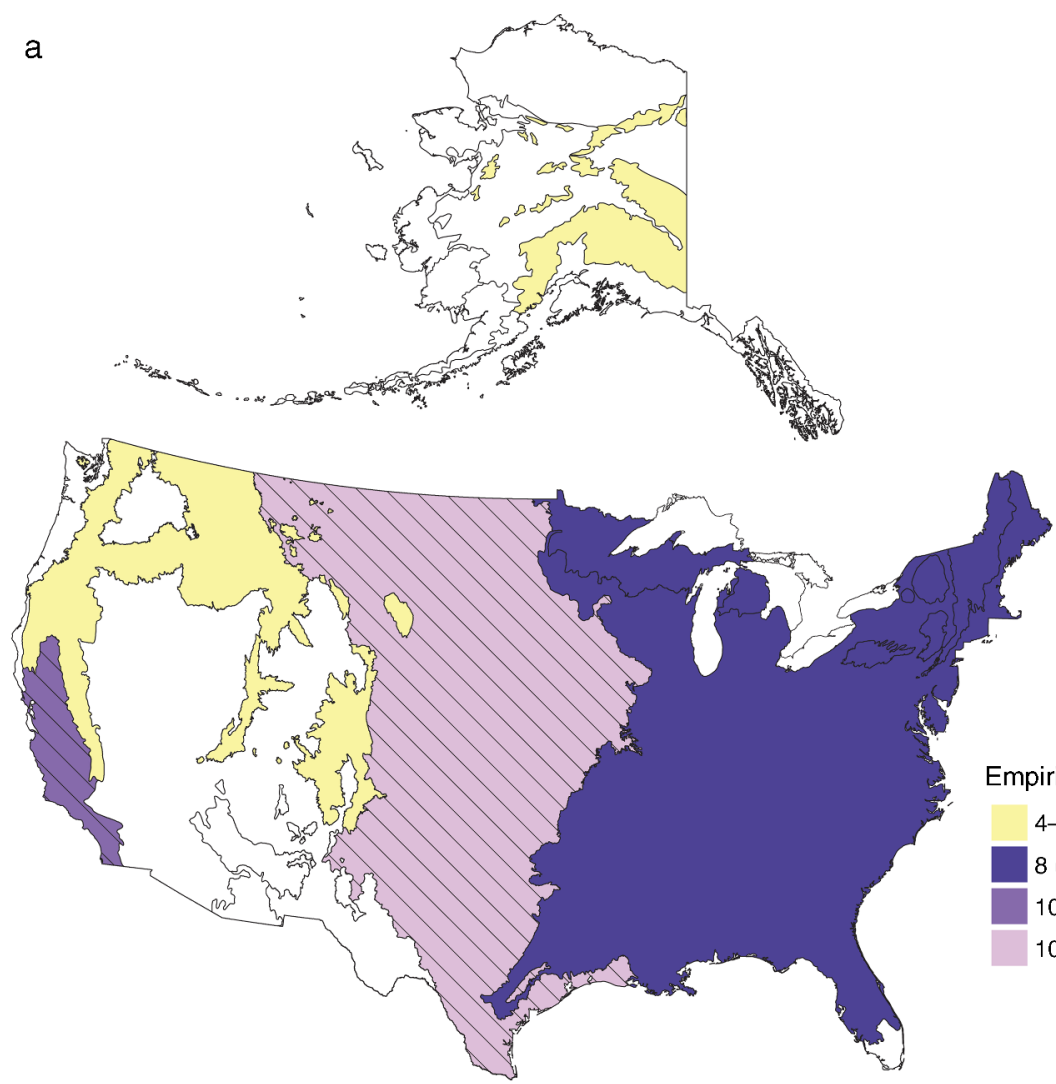

Empirical CL of $\mathrm{N}\left(\mathrm{kg} \cdot \mathrm{ha}^{-1} \cdot \mathrm{yr}^{-1}\right)$

b

4-17 (Northwestern Forested Mountains)

8 (Northern Forests, Eastern Temperate Forests)

10-17 (Mediterranean California)

10-25 (Great Plains)

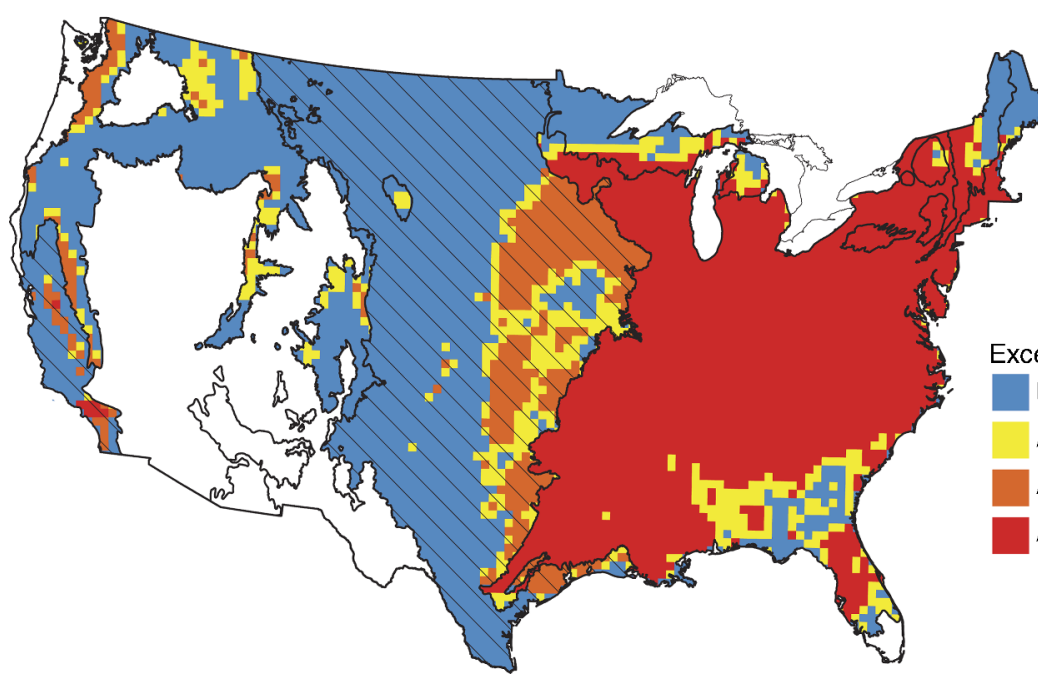

Uncertainty

$\square$ Reliable

$\square$ Fairly reliable

$\triangle$ Expert judgment

FIG. 7. Map of (a) critical loads and (b) exceedances of $\mathrm{N}$ based on increased nitrate leaching by ecoregion in the United States. (a) The range of critical loads based on increased nitrate leaching for each ecoregion. The hatch marks indicate increasing level of uncertainty: no hatch marks for the most certain "reliable" category, single hatching for the "fairly reliable" category, and crosshatching for the "expert judgment" category. The color sequence moves from red toward blue and violet as the critical load increases. As the range of the critical load gets broader, the saturation of the color decreases. (b) Exceedance (critical load deposition) is shown for several categories: (1) no exceedance (below $\mathrm{CL}_{\min }$ ), when deposition is lower than the CL range, (2) at $C L_{\min }$, when deposition is within \pm 1 of the $C L$ range, (3) above $C L_{\min }$, when deposition is above the lower end of the $C L$ range, but lower than the upper end of the range, (4) above $\mathrm{CL}_{\max }$, when deposition is above the upper end of the CL range. CMAQ deposition data were not available for Alaska, so we were not able to calculate exceedance for Alaska. 
surface waters, harming fish species (Baker et al. 1996). Thus, changes in foliar nutrient status or increased nitrification rates are prime candidates for early biogeochemical thresholds that can be very useful for setting critical loads.

\section{Factors that affect the critical load}

One of the objectives of this assessment was to lay the groundwork for further refining and improving estimates of critical loads. Multiple abiotic and biotic factors affect where the value of the critical load falls within the reported range (Table 2). Abiotic influences include a range of climatic, hydrologic, and soil factors that can affect the timing and magnitude of $\mathrm{N}$ delivery to sensitive receptors. Climatic factors include temperature, precipitation amount and distribution, and the extent and rate of climate change. For example, increased precipitation increases the critical load for lichens (see Appendix; Geiser et al. 2010). Hydrologic factors include catchment size, topographic relief, and flow path, which affect the processing and delivery of $\mathrm{NO}_{3}{ }^{-}$to surface waters. Soil factors include soil type, age, depth, coverage, and parent material, all of which can influence soil capacity to store or remove $\mathrm{N}$, and increase a site's critical load. Disturbance may also play a substantial role, for example, $\mathrm{N}$ removal by fire or forest cutting may increase the critical load for nutrient N. Past agricultural land uses may either increase or decrease the critical load depending on their impact on soil nutrients and biotic communities.

Biological factors likely to contribute to lower $\mathrm{N}$ critical loads include particularly sensitive species (diatoms, lichens, mycorrhizal fungi, certain plants), single species vs. community responses, low biomass and low-productivity ecosystems, short life span of receptor of concern, presence of invasive species, and presence of ozone-sensitive species (Grulke et al. 1998, 2009, Grulke and Balduman 1999, Fenn et al. 2008). For example, low-biomass ecosystems (e.g., grasslands, coastal sage scrub, desert) are more sensitive to N-enhanced growth of invasive species, if invasive pressure occurs. These low-biomass ecosystem types sometimes occur because of warm and dry climatic conditions. Because warmer temperatures often correspond to greater metabolic rates, longer periods of biological activity, greater biomass, and more rapid $\mathrm{N}$ cycling, one might expect that the critical load would increase with increasing temperature as has been suggested in Europe (Bobbink et al. 2003). We do not observe such a pattern across U.S. ecoregions in the critical loads reported in this synthesis, but Europe does not have warm and dry deserts with low critical loads as does the United States. Note, however, that the uncertainty of the critical load estimates varies and is often fairly high, which may make it difficult to discern patterns in critical load values across regions. Moreover, a temperature pattern may be confounded by gradients in deposition form and quantity, moisture, and elevation.
The factors discussed in the previous two paragraphs provide general guidance in applying critical loads. In order to set a critical load for a given site, the first step would be to determine whether the site of concern is similar to the site/or sites on which the critical load for that ecosystem type is based. Details on the estimation of critical loads are described by ecoregion in Pardo et al. $(2011 c)$. If the site differs from the sites upon which the critical load is based, Table 2 lists ecoregion-specific factors affecting the critical load that can be useful in adjusting the estimated critical load for a given site.

Note that the magnitude or type of ecosystem change that is unacceptable may vary according to resource management goals or ecosystem services that are valued by a particular stake holder. In a conservation area, for example, any alteration in $\mathrm{N}$ cycling may be considered unacceptable, whereas for other land areas, changes of a certain magnitude or scope may be considered acceptable or desirable based on resource use (such as timber harvesting) or other factors. For example, some responses to low levels of elevated $\mathrm{N}$ deposition, such as increased plant growth and increased $\mathrm{C}$ sequestration by trees (Thomas et al. 2010) may be considered beneficial where forests are managed for tree growth.

The more we are able to identify and quantify the factors that affect the critical load, the more we move towards a mechanistic understanding of the responses, and the better we are able to extrapolate observations across and within ecoregions. In some cases, it may be possible to develop simple empirical relationships as a function of one or several variables that allow us to refine our critical loads estimates. For example, for lichens, Geiser et al. (2010) developed simple regression relationships including precipitation that explain much of the variability in lichen community composition in response to $\mathrm{N}$ deposition, because decreasing precipitation corresponds to exposure to higher concentrations of $\mathrm{N}$. These regression models can be used to estimate critical loads in other regions and also can provide an estimate of the uncertainty associated with the critical load. Such models, strongly tied to empirical observations, will prove invaluable in the development of dynamic models for nutrient $\mathrm{N}$ critical loads.

\section{Uncertainty in critical loads estimates}

There are several sources of uncertainty in our assessment of empirical critical loads beyond those associated with atmospheric deposition (see section Approach: Deposition). These include data gaps, time lags, and effects of multiple stressors.

Data gaps.-In general, there is a dearth of observations on ecosystem response to $\mathrm{N}$ inputs near the critical load. Without extensive, spatially stratified observations, it is not possible to know whether a study site is more or less sensitive than other sites in the ecoregion. The threshold value is best defined by a large number of studies that demonstrate the range of responses observed. 


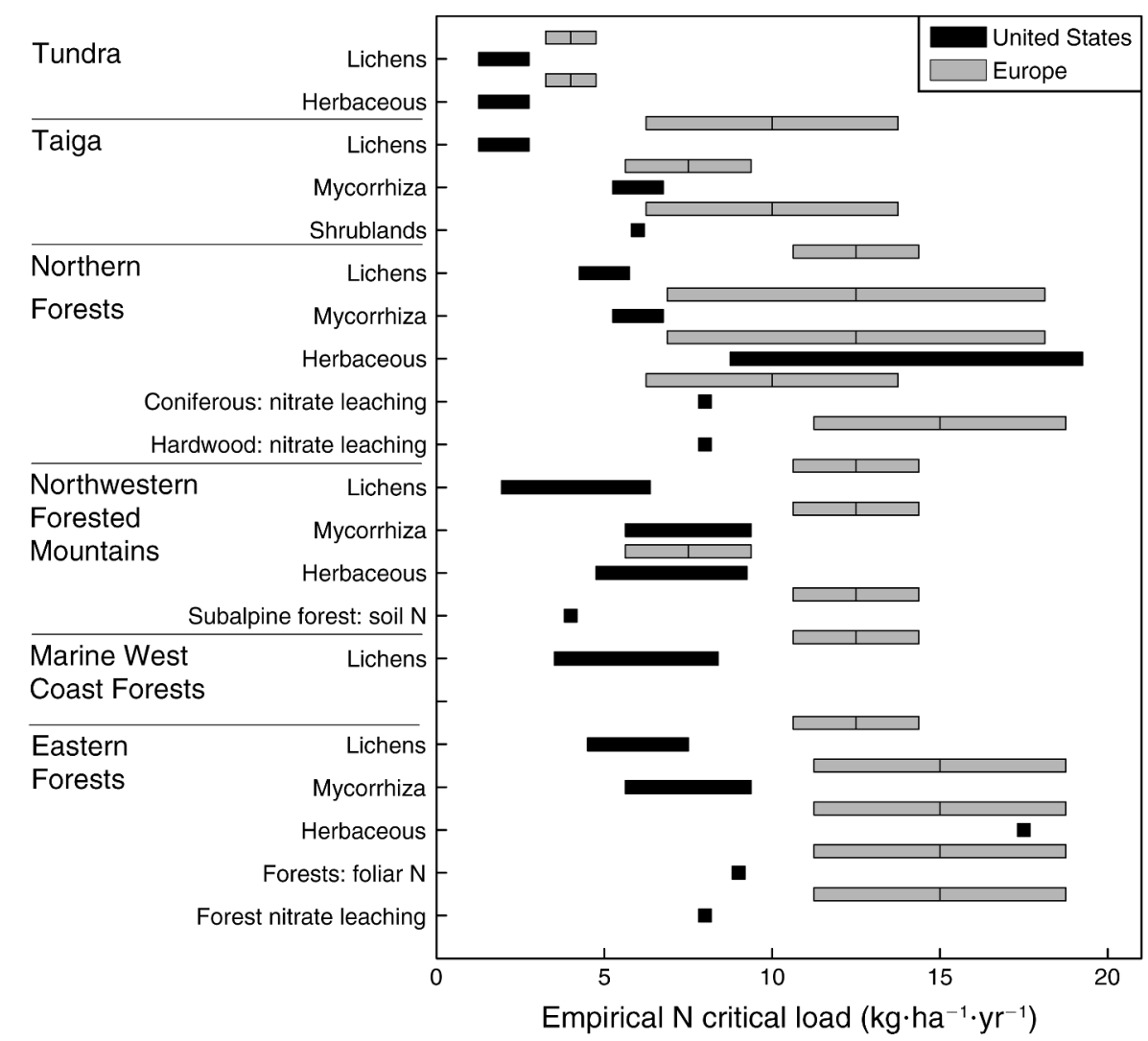

FIG. 8. Comparison of European and U.S. empirical critical loads for nutrient nitrogen. Critical loads for comparable European ecosystems, based on Bobbink and Hettelingh (2011), are typically higher than those reported for U.S. ecoregions. For a number of receptors, the Bobbink and Hettelingh (2011) values are lower than previous empirical critical loads for Europe (Bobbink et al. 2003).

Time lags in the response to $N$ deposition.-Time lags are often observed in $\mathrm{N}$ addition studies, with the magnitude of the time lag a function of the $\mathrm{N}$ residence time and the organisms considered. This time lag increases with life span and size of organism; a tree will respond more slowly than an herbaceous annual, for example. Time lags are also a function of the rate of $\mathrm{N}$ input and the system's capacity for $\mathrm{N}$ storage, with lower rates of input typically leading to longer time lags before an initial response (Clark and Tilman 2008).

Effects of multiple stressors and other confounding variables.-Uncertainty also arises from the confounding effects of multiple stressors and other covariates, especially in $\mathrm{N}$ gradient studies, where it can be difficult to sort out the impact of other factors that vary along the gradient, such as climate, weather, soils, vegetation, disturbances, land use history, and exposure to other pollutants. Multivariate statistics or other approaches can sometimes tease apart effects of $\mathrm{N}$ from other factors, but sometimes correlated stressors can be difficult to separate. In these cases, impacts attributed to $\mathrm{N}$ could actually be the result of a correlated variable or the interaction between the two. On the other hand, because these represent "real-world" conditions (in most locations, multiple stressors co-occur), the critical loads estimated in the presence of these stressors might better protect the ecosystems under the current conditions (Fenn et al. 2008).

Comparison to critical loads in Europe.-With a few exceptions, the critical loads for $\mathrm{N}$ deposition we report for the United States (Pardo et al. 2011a) are lower than those reported for Europe (Fig. 8; Bobbink and Hettelingh 2011). There are several potential reasons, including: greater availability of pristine baselines in the United States, more intensive land use in Europe, greater dominance of $\mathrm{N}$ deposition by reduced forms of $\mathrm{N}$ in Europe, and different threshold criteria.

1. Availability of pristine baselines.-Because of high historic deposition levels, many European systems lack pristine baseline ecosystems as a reference to compare to those experiencing elevated $\mathrm{N}$ deposition. For example, European critical loads for lichens have been much higher than those in the United States (Bobbink et al. 2003). These loads were influenced by study sites in Scotland experiencing a deposition gradient from 10 to $22 \mathrm{~kg} \mathrm{~N} \cdot \mathrm{ha}^{-1} \cdot \mathrm{yr}^{-1}$ from which critical loads were set at 11-18 kg N$\cdot \mathrm{ha}^{-1} \cdot \mathrm{yr}^{-1}$ (Mitchell et al. 2005). However, no oligotrophic species were observed, presumably because they were eliminated prior to the initial studies. 
2. Land use.-A larger fraction of the forested landscape in Europe is heavily managed (harvested and planted) relative to the United States. High rates of harvest removals of $\mathrm{N}$ in biomass, creating greater $\mathrm{N}$ demand and storage during reestablishment of the forest stand could contribute to higher critical loads in Europe than the United States.

3. Forms and mode of measurement of $N$ inputs.$\mathrm{NH}_{4}{ }^{+}$inputs tend to be higher and represent a greater proportion of total $\mathrm{N}$ inputs in Europe, particularly in past decades; this is changing in the United States. Some receptor species can be more sensitive to reduced than oxidized forms of $\mathrm{N}$ inputs, and nitrification of $\mathrm{NH}_{4}^{+}$ inputs can accelerate ecosystem acidification relative to inputs of $\mathrm{NO}_{3}^{-}$.

4. Threshold criteria.-Another possible explanation for the higher critical loads is that the response thresholds utilized in Europe are sometimes higher. For example, choosing a threshold of a shift in lichen community composition will produce a much lower critical load than a threshold of near extirpation of lichen species as used in earlier European work (Bobbink et al. 2003). As a second example, choosing a threshold of initial changes in $\mathrm{N}$ biogeochemistry in the Colorado Front Range interpreted as incipient responses of $\mathrm{N}$ saturation, led to a critical load $<4 \mathrm{~kg}$ $\mathrm{N} \cdot \mathrm{ha}^{-1} \cdot \mathrm{yr}^{-1}$ (Rueth et al. 2003). This is a subtle initial $\mathrm{N}$ enrichment response when compared to the magnitude of change (a later stage of $\mathrm{N}$ saturation) for the critical loads thresholds in Europe (10-15 $\left.\mathrm{kg} \mathrm{N} \cdot \mathrm{ha}^{-1} \cdot \mathrm{yr}^{-1}\right)$.

\section{Conclusions}

The most significant changes that we are currently observing in the United States in response to elevated $\mathrm{N}$ deposition are changes in species composition: losses of $\mathrm{N}$-sensitive species, shifts in dominance, and losses of native species in favor of exotic, invasive species. Shifts in diatom and lichen community composition away from $\mathrm{N}$-intolerant (oligotrophic) species are observed across the country. Alterations in herbaceous species are broadly observed, but are not always clearly documentable because of the long-term pollution inputs and other disturbances (including land use change) that caused changes prior to the initiation of careful observations.

Numerous examples illustrate the significance of these species- and community-level effects. In serpentine grasslands in California, it was clearly demonstrated that, unless $\mathrm{N}$ inputs are decreased or $\mathrm{N}$ is removed in biomass, a larval host plant and numerous nectar source plants utilized by a threatened and endangered butterfly will decrease to levels unable to sustain the checkerspot butterfly population (Weiss 1999, Fenn et al. 2010). In Joshua Tree National Park in southern California, N deposition favors the production of sufficient invasive grass biomass to sustain fires that threaten the survival of the namesake species (Fenn et al. 2010, Rao et al. 2010). Other sensitive ecosystems include alpine meadows, where relatively low levels of $\mathrm{N}$ deposition have already changed species composition (Bowman et al. 2006). Changes in historical diatom community composition from $\mathrm{N}$-limited to $\mathrm{N}$-tolerant species have been observed in lake sediment cores at many locations in the western United States, providing early evidence of freshwater ecosystem eutrophication (Wolfe et al. 2001, 2003).

Changes in ecosystem structure are linked to changes in ecosystem function. For example, extirpation of lichens can alter food webs by reducing the availability of nesting material for birds, invertebrate habitat, and critical winter forage for mammals, and can also affect nutrient cycling (Cornelissen et al. 2007). In some arid low-biomass California ecosystems, N-enhanced growth of invasive species results in increased fire risk, even in areas where fire is normally infrequent (Allen at al. 2009, Fenn et al. 2010, Rao et al. 2010).

There is also evidence of $\mathrm{N}$ deposition contributing to multiple-stress complexes, resulting in reduced forest sustainability (Grulke et al. 2009, McNulty and Boggs 2010). In North Carolina, elevated $\mathrm{N}$ deposition predisposed a pine ecosystem to a pest outbreak following a drought (McNulty and Boggs 2010). These types of complex interactions may be difficult to predict, but may intensify the impact of elevated $\mathrm{N}$ deposition in concert with other stressors, including climate change (Wu and Driscoll 2010). Further examples of changes in ecosystem structure and function are observed in coastal areas, where increased $\mathrm{N}$ export has led to toxic algal blooms (Rabalais 2002). As an example of $\mathrm{N}$ deposition effects on trace gas chemistry and climate change, $\mathrm{N}$ loading to ecosystems results in increased emissions of $\mathrm{N}$ trace gases, such as NO (nitric oxide, an ozone precursor), $\mathrm{N}_{2} \mathrm{O}$ (nitrous oxide, a long-lived and powerful greenhouse gas), as well as declines in soil uptake of $\mathrm{CH}_{4}$ (methane, another long-lived and powerful greenhouse gas) (e.g., Liu and Greaver 2009).

This synthesis demonstrates that elevated $\mathrm{N}$ deposition has altered ecosystem structure and function across the United States. Empirical critical loads for $\mathrm{N}$ provide a valuable approach for evaluating the risk of harm to ecosystems. This approach has been used broadly in Europe (Bobbink et al. 2003, UBA 2004) and has the advantage of being scientifically based on observed responses. This link to actual ecosystem responses is especially beneficial in resource management and policy contexts. This document and Pardo et al. (2011c) provide the first comprehensive assessment of empirical critical loads of $\mathrm{N}$ for ecoregions across the United States. They represent an important step toward providing policymakers and resource managers with a tool for ecosystem protection, as was suggested by the National Research Council (NRC 2004).

\section{Future Research Priorities}

The objective of future research should be better integration of improved atmospheric deposition models, empirical and dynamic critical load models in order to develop critical load and exceedance maps at scales 
useful for regulatory, policy making, land management, and resource protection purposes. A key step in refining critical loads estimates and laying the groundwork for more complex dynamic models is identifying mechanisms that control plant and ecosystem responses to $\mathrm{N}$ deposition. We recommend the following research priorities:

1) Improved quantification of total $\mathrm{N}$ deposition (wet, dry, and cloud/fog), including the measurement of reduced $\left(\mathrm{NH}_{x}\right)$ and organic $\mathrm{N}$.

2) An expanded network of long-term, multi-level, low-N fertilization studies, and adequate $\mathrm{N}$ deposition gradient studies across a greater diversity of ecosystem types and extending to regions of low $\mathrm{N}$ deposition. Such a network would allow development of doseresponse curves for the receptors discussed here that better define the critical load and associated uncertainty.

3) Evaluation of the environmental and ecological factors that influence critical loads for ecoregions and quantifying how the critical load varies as key factors change across ecoregions. In the United States, the sparsest data sets on $\mathrm{N}$ deposition effects are in the tundra, taiga, tropical and subtropical forest, and desert ecoregions.

4) Evaluation of the differential response to reduced vs. oxidized $\mathrm{N}$ inputs. Because some plants are particularly sensitive to $\mathrm{NH}_{x}$ (Krupa 2003), while others are more sensitive to $\mathrm{NO}_{y}$ (Nordin et al. 2006), assembling comprehensive data about species-specific responses would allow more accurate assessment of potential risks to ecosystems in relation to the major $\mathrm{N}$ emissions sources.

5) Use of methods that can account for effects on longer lived organisms, and lack of pristine baselines caused by historical $\mathrm{N}$ deposition, other pollutants, or habitat alteration, e.g., dendrochronology, paleolimnology.

6) Quantification of effects of $\mathrm{N}$ deposition on forest growth and susceptibility to secondary stressors. Insufficient data are available to determine critical loads for the effects of increasing $\mathrm{N}$ inputs on pest outbreaks, drought, cold tolerance, tree vigor, and other multiplestress complexes.

\section{ACKNOWLEDGMENTS}

This project was funded, in part, by the US-EPA Clean Air Markets Division, DW-12-92196101. Initial work on this project was funded by the USDA Forest Service Air Resource Management Program. Funding was provided by the UCR Center for Conservation Biology and NSF grant DEB 0421530. We thank Amanda Elliot Lindsey and Robert Johnson for their assistance in creating deposition and critical loads maps. We thank Sabine Braun, Doug Burns, and Jim Sickman for their reviews of an earlier version of the manuscript. We thank Sabine Braun for the concept for Fig. 8. We appreciate the comments of two anonymous reviewers.

\section{Literature Cited}

Aber, J. D., C. L. Goodale, S. V. Ollinger, M.-L. Smith, A. H. Magill, M. E. Martin, R. A. Hallet, and J. L. Stoddard. 2003.
Is nitrogen deposition altering the nitrogen status of Northeastern forests? BioScience 53(4):375-389.

Aber, J., W. McDowell, K. Nadelhoffer, A. Magill, G. Berntson, M. Kamakea, S. McNulty, W. Currie, L. Rustad, and I. Fernandez. 1998. Nitrogen saturation in temperate forest ecosystems. BioScience 48:921-934.

Aber, J. D., K. J. Nadelhoffer, P. Steudler, and J. M. Melillo. 1989. Nitrogen saturation in northern forest ecosystems. BioScience 39:378-386.

Adams, M. B., D. R. DeWalle, W. T. Peterjohn, F. S. Gilliam, W. E. Sharpe, and K. W. J. Williard. 2006. Soil chemical responses to experimental acidification treatments. Pages 4169 in M. B. Adams, D. R. DeWalle, and J. L. Hom, editors. The Fernow Watershed acidification study. Springer-Verlag, Dordrecht, The Netherlands.

Aldous, A. R. 2002. Nitrogen retention by Sphagnum mosses: responses to atmospheric nitrogen deposition and drought. Canadian Journal of Botany 80:721-731.

Allen, E. B., L. E. Rao, R. J. Steers, A. Bytnerowicz, and M. E. Fenn. 2009. Impacts of atmospheric nitrogen deposition on vegetation and soils in Joshua Tree National Park. Pages 78100 in R. H. Webb, L. F. Fenstermaker, J. S. Heaton, D. L. Hughson, E. V. McDonald, and D. M. Miller, editors. The Mojave Desert: ecosystem processes and sustainability. University of Nevada Press, Las Vegas, Nevada, USA.

Allen, E. B., P. J. Temple, A. Bytnerowicz, M. J. Arbaugh, A. G. Sirulnik, and L. E. Rao. 2007. Patterns of understory diversity in mixed coniferous forests of southern California impacted by air pollution. Scientific World Journal 7(S1):247-263. [doi: 10.1100/tsw.2007.72]

Amaranthus, M. P. 1998. The importance and conservation of ectomycorrhizal fungal diversity in forest ecosystems: Lessons from Europe and the Pacific Northwest. General Technical Report PNW QTR-431. USDA Forest Service, Portland, Oregon, USA.

Arens, S. J. T., P. F. Sullivan, and J. M. Welker. 2008. Nonlinear responses to nitrogen and strong interactions with nitrogen and phosphorus additions drastically alter the structure and function of a high arctic ecosystem. Journal of Geophysical Research-Biogeosciences 113:G03S09.

Baez, S., J. Fargione, D. I. Moore, S. L. Collins, and J. R. Gosz. 2007. Atmospheric nitrogen deposition in the northern Chihuahuan desert: Temporal trends and potential consequences. Journal of Arid Environments 68:640-651.

Baker, J. P., J. Van Sickle, C. J. Gagen, B. P. Baldigo, D. W. Bath, R. F. Carline, D. R. DeWalle, W. A. Kretser, P. S. Murdoch, W. E. Sharpe, H. A. Simonin, and P. J. Wigington. 1996. Episodic acidification of small streams in the northeastern United States: effects on fish populations. Ecological Applications 6:422-437.

Baron, J. S. 2006. Hindcasting nitrogen deposition to determine ecological critical load. Ecological Applications 16:433-439.

Baron, J. S., C. T. Driscoll, and J. L. Stoddard. 2011. Inland surface waters. Pages 209-227 in L. H. Pardo, M. J. RobinAbbott, and C. T. Driscoll, editors. Assessment of nitrogen deposition effects and empirical critical loads of nitrogen for ecoregions of the United States. General Technical Report NRS-80. USDA Forest Service, Northern Research Station, Newtown Square, Pennsylvania, USA.

Baron, J. S., D. S. Ojima, E. A. Holland, and W. J. Parton. 1994. Analysis of nitrogen saturation potential in Rocky Mountain tundra and forest: implications for aquatic systems. Biogeochemistry 27:61-82.

Baron, J. S., H. M. Rueth, A. M. Wolfe, K. R. Nydick, E. J. Allstott, J. T. Minear, and B. Moraska. 2000. Ecosystem responses to nitrogen deposition in the Colorado Front Range. Ecosystems 3:352-368.

Barret, J. E., and I. C. Burke. 2002. Nitrogen retention in semiarid ecosystems across a soil organic-matter gradient. Ecological Applications 12:878-890.

Belyazid, S., O. Westling, and H. Sverdrup. 2006. Modelling changes in forest soil chemistry at 16 Swedish coniferous 
forest sites following deposition reduction. Environmental Pollution 144:596-609.

Berryman, S., and J. Straker. 2008. Nitrogen loading and terrestrial vegetation-assessment of existing regional monitoring and recommendations. Report prepared for the Cumulative Environmental Management Association $\mathrm{NO}_{x^{-}}$ $\mathrm{SO}_{2}$ Management Working Group and Eutrophication Task Group. C. E. Jones and Associates, Sidney, British Columbia, Canada.

Berryman, S., L. Geiser, and G. Brenner. 2004. Depositional gradients of atmospheric pollutants in the Athabasca Oil Sands region, Alberta, Canada: an analysis of lichen tissue and lichen communities. Lichen Indicator Pilot Program 2002-2003. Final Report Submitted to the Terrestrial Environmental Effects Monitoring (TEEM) Science Subcommittee of the Wood Buffalo Environmental Association (WBEA). February 25, 2004. Ft. McMurray, Alberta, Canada.

Blett, T., L. Geiser, and E. Porter. 2003. Air pollution-related lichen monitoring in national parks, forests, and refuges. Guidelines of studies intended for regulatory and management purposes. Technical Report NPS D2292. USDI national Park Service Air Resources Division, Denver, Colorado, USA.

Bobbink, R., M. Ashmore, S. Braun, W. Flückinger, and I. J. J. van den Wyngaert. 2003. Empirical nitrogen critical loads for natural and semi-natural ecosystems: 2002 update. Pages 43107 in B. Achermann and R. Bobbick, editors. Empirical critical loads for nitrogen. Environmental Documentation Number 164. Swiss Agency for the Environment, Forests, and Landscape, Berne, Switzerland.

Bobbink, R., D. Boxman, E. Fremstad, G. Heil, A. Houdijk, and J. Roelofs. 1992. Critical loads for nitrogen eutrophication of terrestrial and wetland ecosystems based upon changes in vegetation and fauna. Pages 111-159 in Grennfelt and Thörnelöf, editors. Critical loads for nitrogen. Nord 41. Nordic Council of ministers, Copenhagen, Denmark.

Bobbink, R., and J. P. Hettelingh, editors. 2011. Review and revision of empirical critical loads and dose-response relationships. RIVM Report 680359002. Coordination Centre for Effects, National Institute for Public Health and the Environment (RIVM), Bilthoven, The Netherlands. 〈www. rivm.nl/cce)

Bobbink, R., et al. 2010. Global assessment of nitrogen deposition effects on terrestrial plant diversity: a synthesis. Ecological Applications 20:30-59.

Bobbink, R., M. Hornung, and J. G. M. Roelofs. 1998. The effects of air-borne nitrogen pollutants on species diversity in natural and semi-natural European vegetation. Journal of Ecology 86:738.

Boonpragob, K., T. H. Nash III, and C. A. Fox. 1989. Seasonal deposition patterns of acidic ions and ammonium to the lichen Ramalina menziesii Tayl. in Southern California. Environmental and Experimental Botany 29:187-197.

Bowman, W. D., J. R. Larson, K. Holland, M. Wiedermann, and J. Nieves. 2006. Nitrogen critical loads for alpine vegetations and ecosystem response: Are we there yet? Ecological Applications 16:1183-1193.

Breiner, J., B. S. Gimeno, and M. Fenn. 2007. Calculation of theoretical and empirical nutrient $\mathrm{N}$ critical loads in the mixed-conifer ecosystems of southern California. Scientific World Journal 7(S1):198-205.

Burns, D. A., T. Blett, R. Haeuber, and L. H. Pardo. 2008. Critical loads as a policy tool for protecting ecosystems from the effects of air pollutants. Frontiers in Ecology and the Environment 6:156-159. [doi: 10.1890/070040]

Byun, D. W., and J. K. S. Ching, editors. 1999. Science algorithms of the EPA models-3 community multiscale air quality model (CMAQ) modeling system. EPA/600/R-99/ 030. U.S. Environmental Protection Agency, Office of Research and Development, Washington, D.C., USA.
〈http://www.epa.gov/asmdnerl/CMAQ/CMAQscienceDoc. html $\rangle$

Byun, D., and K. L. Schere. 2006. Review of the governing equations, computational algorithms, and other components of the Models-3 Community Multiscale Air Quality (CMAQ) modeling system. Applied Mechanics Reviews 59:51-77.

Caffrey, J. M., M. C. Murrell, C. Wigand, and R. McKinney. 2007. Effect of nutrient loading on biogeochemical and microbial processes in a New England salt marsh. Biogeochemistry 82:251-264.

Cape, J. N., L. J. van der Eerden, L. J. Sheppard, I. D. Leith, and M. A. Sutton. 2009. Pages 15-40 in M. Sutton, S. Reis, and S. M. H. Baker, editors. Atmospheric ammonia. Springer Science, Dordrecht, The Netherlands.

CEC [Commission for Environmental Cooperation]. 1997. Ecological regions of North America. Toward a common perspective. CEC, Montreal, Quebec, Canada. 〈http://www. cec.org/files/pdf/BIODIVERSITY/eco-engEN.pdf $\rangle$

Clark, C. M., S. Hobbie, R. Venterea, and D. Tilman. 2009. Long-lasting effects on $\mathrm{N}$ cycling 12 years after treatments cease despite minimal $\mathrm{N}$ retention. Global Change Biology $15: 1755-1766$

Clark, C. M., and D. Tilman. 2008. Loss of plant species after chronic low-level nitrogen deposition to prairie grasslands. Nature 451:712-715.

Clark, J. E., E. C. Hellgren, E. E. Jorgensen, and D. M. Leslie. 2005. Population dynamics of harvest mice (Reithrodontomys fulvescens and $R$. montanus) across a nitrogen-amended old field. American Midland Naturalist 154:240-252.

Clark, J. E., E. C. Hellgren, E. E. Jorgensen, S. J. Tunnell, D. M. Engle, and D. M. Leslie. 2003. Population dynamics of hispid cotton rats (Sigmodon hispidus) across a nitrogenamended landscape. Canadian Journal of Zoology 81:9941003.

Cornelissen, J. H. C., S. I. Lang, N. A. Soudzilovskaia, and H. J. During. 2007. Comparative cryptogam ecology: a review of bryophyte and lichen traits that drive biogeochemistry. Annals of Botany 99:987-1001.

de Vries, W., et al. 2007. Developments in modelling critical nitrogen loads for terrestrial ecosystems in Europe. Report 1382. Alterra Wageningen UR, Wageningen, The Netherlands.

de Vries, W., et al. 2010. Use of dynamic soil-vegetation models to assess impacts of nitrogen deposition on plant species composition: an overview. Ecological Applications 20:60-79.

Dighton, J., A. R. Tuininga, D. M. Gray, R. E. Huskins, and T. Belton. 2004. Impacts of atmospheric deposition on New Jersey pine barren forest soils and communities of ectomycorrhizae. Forest Ecology and Management 201:131-144.

Driscoll, C. T., G. B. Lawrence, A. J. Bulger, T. J. Butler, C. S. Cronan, C. Eagar, K. F. Lambert, G. E. Likens, J. L. Stoddard, and K. C. Weathers. 2001. Acidic deposition in the northeastern United States: Sources and inputs, ecosystem effects, and management strategies. BioScience 51:180-198.

Driscoll, C. T., D. Whitall, J. Aber, E. Boyer, M. Castro, C. Cronan, C. L. Goodale, P. Groffman, C. Hopkinson, K. Lambert, G. Lawrence, and S. Ollinger. 2003. Nitrogen pollution in the northeastern United States: sources, effects, and management options. BioScience 53:357-374.

Dupont, J., T. A. Clair, C. Gagnon, D. S. Jeffries, J. S. Kahl, S. Nelson, and J. Peckenham. 2005. Estimation of critical loads of acidity for lakes in northeastern United States and eastern Canada. Environmental Monitoring Assessment 109:275292.

Egerton-Warburton, L. M., and E. B. Allen. 2000. Shifts in arbuscular mycorrhizal communities along an anthropogenic nitrogen deposition gradient. Ecological Applications 10:484-496.

Egerton-Warburton, L. M., R. C. Graham, E. B. Allen, and M. F. Allen. 2001. Reconstruction of the historical changes in mycorrhizal fungal communities under anthropogenic nitro- 
gen deposition. Proceedings of the Royal Society of London B 268:2479-2484.

Elser, J. J., T. Anderson, J. S. Baron, A.-K. Bergström, M. Kyle, K. R. Nydick, L. Steger, and D. O. Hessen. 2009. Shifts in lake N:P stoichiometry and nutrient limitation driven by atmospheric nitrogen deposition. Science 326:835-837.

Environment Canada. 2008. Canada-United States air quality agreement progress report. Environment Canada, Gatineau, Quebec, Canada. 〈http://www.ec.gc.ca/Publications/D8E5913D0A85-4BE4-AD67-B627D0C0FE87/CanadaUnitedStatesAir QualityAgreementProgressReport2008.pdf $\rangle$

Epstein, H. E., I. C. Burke, and A. R. Mosier. 2001. Plant effects on nitrogen retention in shortgrass steppe 2 years after ${ }^{15} \mathrm{~N}$ addition. Oecologia 128:422-430.

Falkengren-Grerup, U. 1995. Interspecies differences in the preference of ammonium and nitrate in vascular plants. Oecologia 102:305-311.

Fenn, M. E., E. B. Allen, and L. H. Geiser. 2011. Mediterranean California. Pages 143-169 in L. H. Pardo, M. J. RobinAbbott, and C. T. Driscoll, editors. Assessment of nitrogen deposition effects and empirical critical loads of nitrogen for ecoregions of the United States. General Technical Report NRS-80. USDA Forest Service, Northern Research Station, Newtown Square, Pennsylvania, USA.

Fenn, M. E., E. B. Allen, S. B. Weiss, S. Jovan, L. Geiser, G. S. Tonnesen, R. F. Johnson, L. E. Rao, B. S. Gimeno, F. Yuan, T. Meixner, and A. Bytnerowicz. 2010. Nitrogen critical loads and management alternatives for $\mathrm{N}$-impacted ecosystems in California. Journal of Environmental Management 91:2404-2423.

Fenn, M. E., J. S. Baron, E. B. Allen, H. M. Rueth, K. R. Nydick, L. Geiser, W. D. Bowman, J. O. Sickman, T. Meixner, D. W. Johnson, and P. Neitlich. 2003a. Ecological effects of nitrogen deposition in the western United States. BioScience 53:404-420.

Fenn, M. E., L. I. de Bauer, A. Quevedo-Nolasco, and C. Rodriguez-Frausto. 1999. Nitrogen and sulfur deposition and forest nutrient status in the Valley of Mexico. Water, Air, and Soil Pollution 113:155-174.

Fenn, M. E., L. I. de Bauer, K. Zeller, A. Quevedo, C. Rodríguez, and T. Hernández-Tejeda. 2002. Nitrogen and sulfur deposition in the Mexico City Air Basin: Impacts on forest nutrient status and nitrate levels in drainage waters. Pages 298-319 in M. E. Fenn, L. I. de Bauer, and T. Hernández-Tejeda, editors. Urban air pollution and forests: resources at risk in the Mexico City air basin. Ecological Studies Series, Volume 156. Springer-Verlag, New York, New York, USA.

Fenn, M. E., and L. H. Geiser. 2011. Temperate sierra. Pages 175-180 in L. H. Pardo, M. J. Robin-Abbott, and C. T. Driscoll, editors. Assessment of nitrogen deposition effects and empirical critical loads of nitrogen for ecoregions of the United States. General Technical Report NRS-80. USDA Forest Service, Northern Research Station, Newtown Square, Pennsylvania, USA.

Fenn, M. E., R. Haueber, G. S. Tonnensen, J. S. Baron, S. Grossman-Clarke, D. Hope, D. A. Jaffe, S. Copeland, L. Geiser, H. M. Rueth, and J. O. Sickman. 2003b. Nitrogen emission, deposition, and monitoring in the Western United States. BioScience 53:391-403.

Fenn, M. E., S. Jovan, F. Yuan, L. Geiser, T. Meixner, and B. S. Gimeno. 2008. Empirical and simulated critical loads for nitrogen deposition in California mixed conifer forests. Environmental Pollution 155:492-511.

Fenn, M. E., and M. A. Poth. 1999. Temporal and spatial trends in streamwater nitrate concentrations in the San Bernardino Mountains, southern California. Journal of Environmental Quality 28:822-836.

Fenn, M. E., M. A. Poth, A. Bytnerowicz, J. O. Sickman, and B. K. Takemoto. 2003c. Effects of ozone, nitrogen deposition, and other stressors on montane ecosystems in the Sierra Nevada. Pages 111-155 in A. Bytnerowicz, M. J. Arbaugh, and R. Alonso, editors. Developments in environmental science. Volume 2. Ozone air pollution in the Sierra Nevada: distribution and effects on forests. Elsevier, Amsterdam, The Netherlands.

Fenn, M. E., J. O. Sickman, A. Bytnerowicz, D. W. Clow, N. P. Molotch, J. E. Pleim, G. S. Tonnesen, K. C. Weathers, P. E. Padgett, and D. H. Campbell. 2009. Methods for measuring atmospheric nitrogen deposition inputs in arid and montane ecosystems of western North America. Pages 179-228 in A. H. Legge, editor. Developments in environmental science. Volume 9. Air quality and ecological impacts: relating sources to effects. Elsevier, Amsterdam, The Netherlands.

Galloway, J. N. 1998. The global nitrogen cycle: changes and consequences. Environmental Pollution 102:15-24.

Galloway, J. N., J. D. Aber, J. W. Erisman, S. P. Seitzinger, R. W. Howarth, E. B. Cowling, and B. J. Cosby. 2003. The nitrogen cascade. BioScience 53:341-356.

Galloway, J. N., et al. 2004. Nitrogen cycles: past, present, and future. Biogeochemistry 70:153-226.

Geiser, L. H., A. R. Ingersoll, A. Bytnerowicz, and S. A. Copeland. 2008. Evidence of enhanced atmospheric ammoniacal nitrogen in Hells Canyon NRA: Implications for natural and cultural resources. Journal of the Air and Waste Management Association 58:1223-1234.

Geiser, L. H., S. E. Jovan, D. A. Glavich, and M. Porter. 2010. Lichen-based critical loads for nitrogen deposition in western Oregon and Washington Forests, USA. Environmental Pollution 158:2412-2421.

Geiser, L. H., and P. N. Neitlich. 2007. Air pollution and climate gradients in western Oregon and Washington indicated by epiphytic macrolichens. Environmental Pollution 145:203-218.

Gilliam, F. S. 2006. Response of the herbaceous layer of forest ecosystems to excess nitrogen deposition. Journal of Ecology 94:1176-1191.

Gilliam, F. S. 2007. The ecological significance of the herbaceous layer in forest ecosystems. BioScience 57:845858.

Gilliam, F. S., M. B. Adams, and B. M. Yurish. 1996. Ecosystem nutrient responses to chronic nitrogen inputs at Fernow Experimental Forest, West Virginia. Canadian Journal of Forest Research 26:196-205.

Gilliam, F. S., A. W. Hockenberry, and M. B. Adams. 2006. Effects of atmospheric nitrogen deposition on the herbaceous layer of a central Appalachian hardwood forest. Journal of the Torrey Botanical Society 133:240-254.

Glavich, D. A., and L. H. Geiser. 2008. Potential approaches to developing lichen-based critical loads and levels for nitrogen, sulfur and metal-containing atmospheric pollutants in North America. Bryologist 111:638-649.

Gotelli, N. J., and A. M. Ellison. 2002. Nitrogen deposition and extinction risk in the northern pitcher plant, Sarracenia purpurea. Ecology 83:2758-2765.

Gotelli, N. J., and A. M. Ellison. 2006. Forecasting extinction risk with nonstationary matrix models. Ecological Applications 16:51-61.

Greaver, T., L. Liu, and R. Bobbink. 2011. Wetlands. Pages 193-208 in L. H. Pardo, M. J. Robin-Abbott, and C. T. Driscoll, editors. Assessment of nitrogen deposition effects and empirical critical loads of nitrogen for ecoregions of the United States. General Technical Report NRS-80. USDA Forest Service, Northern Research Station, Newtown Square, Pennsylvania, USA.

Grulke, N. E., C. P. Andersen, M. E. Fenn, and P. R. Miller. 1998. Ozone exposure and nitrogen deposition lowers root biomass of ponderosa pine in the San Bernardino Mountains, California. Environmental Pollution 103:63-73.

Grulke, N. E., and L. Balduman. 1999. Deciduous conifers: high $\mathrm{N}$ deposition and $\mathrm{O}_{3}$ exposure effects on growth and biomass allocation in ponderosa pine. Water, Air and Soil Pollution 116:235-248. 
Grulke, N. E., R. A. Minnich, T. D. Paine, S. J. Seybold, D. J Chavez, M. E. Fenn, P. J. Riggan, and A. Dunn. 2009. Air pollution increases forest susceptibility to wildfires: a case study in the San Bernardino Mountains in southern California. Pages 365-403 in A. Bytnerowicz, M. J. Arbaugh, A. R. Riebau, and C. Andersen, editors. Wildland fires and air pollution. Developments in Environmental Science, Volume 8. Elsevier, Amsterdam, The Netherlands.

Hettelingh, J.-P., M. Posch, and J. Slootweg, editors. 2008. Critical load, dynamic modelling and impact assessment in Europe. CCE Status Report 2008. Coordination Centre for Effects, Netherlands Environmental Assessment Agency, Bilthoven, The Netherlands. 〈http://www.rivm.nl/thema/en/ themasites/cce/index.html $\rangle$

Hurd, T. M., A. R. Brach, and D. J. Raynal. 1998. Response of understory vegetation of Adirondack forests to nitrogen additions. Canadian Journal of Forest Research 28:799-807.

Hyvärinen, M., B. Walter, and R. Koopmann. 2003. Impact of fertilisation on phenol content and growth rate of Cladina stellaris: a test of the carbon-nutrient balance hypothesis. Oecologia 134:176-181.

Inouye, R. S. 2006. Effects of shrub removal and nitrogen addition on soil moisture in sagebrush steppe. Journal of Arid Environments 65:604-618.

Jones, M. E., T. D. Paine, M. E. Fenn, and M. A. Poth. 2004. Influence of ozone and nitrogen deposition on bark beetle activity under drought conditions. Forest Ecology and Management 200:67-76.

Jorgensen, E. E., et al. 2005. Ecosystem stress from chronic exposure to low levels of nitrate. EPA/600/R-05/087. U.S. Environmental Protection Agency, National Risk Management Research Laboratory, Cincinnati, Ohio, USA.

Jovan, S. 2008. Lichen bioindication of biodiversity, air quality, and climate: baseline results from monitoring in Washington, Oregon, and California. General Technical Report PNWGTR-737. USDA Forest Service, Pacific Northwest Research Station, Portland, Oregon, USA.

Jovan, S., and B. McCune. 2005. Air quality bioindication in the greater Central Valley of California with epiphytic macrolichen communities. Ecological Applications 15:17121726.

Kelly, V. R., G. M. Lovett, K. C. Weathers, and G. E. Likens. 2005. Trends in atmospheric ammonium concentrations in relation to atmospheric sulfate and local agriculture. Environmental Pollution 135:363-369.

Kleijn, D., R. M. Bekker, R. Bobbink, M. C. C. de Graaf, and J. G. M. Roelofs. 2008. In search for key biogeochemical factors affecting plant species persistence in heathlands and acidic grasslands: a comparison of common and rare species. Journal of Applied Ecology 45:680-687.

Knops, J. M. H., T. H. Nash III, V. L. Boucher, and W. L. Schlesinger. 1991. Mineral cycling and epiphytic lichens: implications at the ecosystem level. Lichenologist 23:309321.

Krupa, S. V. 2003. Effects of atmospheric ammonia $\left(\mathrm{NH}_{3}\right)$ on terrestrial vegetation: a review. Environmental Pollution 124:179-221.

Kytöviita, M.-M., and P. D. Crittenden. 2007. Growth and nitrogen relations in the mat-forming lichens Stereocaulon paschale and Cladonia stellaris. Annals of Botany 100:15371545.

Lafrancois, B. M., K. R. Nydick, B. M. Johnson, and J. S. Baron. 2004. Cumulative effects of nutrients and $\mathrm{pH}$ on the plankton of two mountain lakes. Canadian Journal of Fisheries and Aquatic Science 61:1153-1165.

Latimer, J. S., and S. A. Rego. 2010. Empirical relationship between eelgrass extent and predicted watershed-derived nitrogen loading for shallow New England estuaries. Estuarine, Coastal and Shelf Science 90:231-240.

LeBauer, D. S., and K. K. Treseder. 2008. Nitrogen limitation of net primary productivity in terrestrial ecosystems is globally distributed. Ecology 89:371-379.
Lehmann, C. M. B., V. C. Bowersox, and S. M. Larson. 2005. Spatial and temporal trends of precipitation chemistry in the United States, 1985-2002. Environmental Pollution 135:347361 .

Lilleskov, E. A. 1999. Decline of above- and belowground ectomycorrhizal fungal diversity over an atmospheric nitrogen deposition gradient near Kenai, Alaska. Dissertation. Cornell University, Ithaca, New York, USA.

Lilleskov, E. A. 2005. How do composition, structure, and function of mycorrhizal fungal communities respond to nitrogen deposition and ozone exposure? Pages 769-801 in J. Dighton, J. F. White, P. Oudemans, editors. The fungal community: its organization and role in the rcosystem. Taylor and Francis, Boca Raton, Florida, USA.

Lilleskov, E. A., T. J. Fahey, T. R. Horton, and G. M. Lovett. 2002. Belowground ectomycorrhizal fungal community change over a nitrogen deposition gradient in Alaska. Ecology 83:104-115.

Lilleskov, E. A., T. J. Fahey, and G. M. Lovett. 2001. Ectomycorrhizal fungal aboveground community change over an atmospheric nitrogen deposition gradient. Ecological Applications 11:397-410.

Lilleskov, E. A., P. M. Wargo, K. A. Vogt, and D. J. Vogt. 2008. Mycorrhizal fungal community relationship to root nitrogen concentration over a regional atmospheric nitrogen deposition gradient in the northeastern US. Canadian Journal of Forest Research 38:1260-1266.

Liu, L., and T. L. Greaver 2009. A review of nitrogen enrichment effects on three biogenic GHGs: The $\mathrm{CO}_{2}$ sink may be largely offset by stimulated $\mathrm{N}_{2} \mathrm{O}$ and $\mathrm{CH}_{4}$ emission. Ecology Letters 12:1103-1117.

Lovett, G. M., T. Tear, D. Evers, S. E. G. Findlay, B. J. Cosby, J. Dunscomb, C. Driscoll, and K. C. Weathers. 2009. Effects of air pollution on ecosystems and biological diversity in the eastern United States. Annals of the New York Academy of Sciences 1162:99-135.

Makkonen, S., R. S. K. Hurri, and M. Hyvarinen. 2007. Differential responses of lichen symbionts to enhanced nitrogen and phosphorus availability: an experiment with Cladina stellaris. Annals of Botany 99:877-884.

McCune, B. M., and L. H. Geiser. 2009. Macrolichens of the Pacific Northwest. Second edition. Oregon State University Press, Corvallis, Oregon, USA.

McCune, B., J. Grenon, L. S. Mutch, and E. P. Martin. 2007. Lichens in relation to management issues in the Sierra Nevada national parks. Pacific Northwest Fungi 2:1-39.

McKane, R. B., L. C. Johnson, G. R. Shaver, K. J. Nadelhoffer, E. B. Rastetter, B. Fry, A. E. Giblin, K. Kielland, B. L. Kwiatkowski, J. A. Laundre, and G. Murray. 2002. Resource-based niches provide a basis for plant species diversity and dominance in arctic tundra. Nature 415:68-71.

McNulty, S. G., and J. L. Boggs. 2010. A conceptual framework: redefining forest soil's critical acid loads under a changing climate. Environmental Pollution 158:2053-2058.

McNulty, S. G., J. Boggs, J. D. Aber, L. Rustad, and A. Magill. 2005. Red spruce ecosystem level changes following 14 years of chronic $\mathrm{N}$ fertilization. Forest Ecology and Management 219:279-291.

McNulty, S. G., E. C. Cohen, J. A. M. Myers, T. J. Sullivan, and H. Li. 2007. Estimates of critical acid loads and exceedances for forest soils across the conterminous United States. Environmental Pollution 149:281-292.

Meixner, T., and M. Fenn. 2004. Biogeochemical budgets in a Mediterranean catchment with high rates of atmospheric $\mathrm{N}$ deposition: importance of scale and temporal asynchrony. Biogeochemistry 70:331-356.

Michel, T. J., J. E. Saros, S. J. Interlandi, and A. P. Wolfe. 2006. Resource requirements of four freshwater diatom taxa determined by in situ growth bioassays using natural populations from alpine lakes. Hydrobiologia 568:235-243.

Miller, A. E., and W. D. Bowman. 2002. Variation in nitrogen15 natural abundance and nitrogen uptake traits among co- 
occurring alpine species: do species partition nitrogen form? Oecologia 130:609-616.

Mitchell, R. J., A. M. Truscot, I. D. Leith, J. N. Cape, N. van Dijk, Y. S. Tang, D. Fowler, and M. A. Sutton. 2005. A study of epiphytic communities of Atlantic oak woods along an atmospheric nitrogen deposition gradient. Journal of Ecology 93:482-492.

Moore, T., C. Blodau, J. Turunen, N. Roulet, and P. J. H. Richard. 2004. Patterns of nitrogen and sulfur accumulation and retention in ombrotrophic bogs, eastern Canada. Global Change Biology 11:256-367.

NADP [National Atmospheric Deposition Program]. 2009. Atmospheric integrated research monitoring network. NADP, Champaign, Illinois, USA. 〈http://nadp.sws.uiuc. edu/airmon/>

NEG/ECP [New England Governors and Eastern Canadian Premiers] Forest Mapping Group. 2003. Assessment of forest sensitivity to nitrogen and sulfur deposition in New England and Eastern Canada: pilot phase report. Conference of the New England Governors and Eastern Canadian Premiers, Boston, Massachusetts, USA. 〈http://www.ecosystems-research.com/ fmi/VT-NF-Forest-Sensitivity-Report.pdf $\rangle$

Nilles, M. A., and B. E. Conley. 2001. Changes in the chemistry of precipitation in the United States, 1981-1998. Water, Air and Soil Pollution 130:409-414.

Nordin, A., J. Strengbom, and L. Ericson. 2006. Responses to ammonium and nitrate additions by boreal plants and their natural enemies. Environmental Pollution 141:167-174.

Nordin, A., J. Strengbom, J. Witzell, T. Näsholm, and L. Ericson. 2005. Nitrogen deposition and the biodiversity of boreal forests: Implications for the nitrogen critical load. Ambio 34:20-24.

NRC [National Research Council]. 2004. Air quality management in the United States. National Academy of Sciences Press, Washington, D.C., USA.

Nydick, K. R., B. M. Lafrancois, J. S. Baron, and B. M. Johnson. 2004. Nitrogen regulation of algal biomass, productivity, and composition in shallow mountain lakes, Snowy Range, Wyoming, USA. Canadian Journal of Fisheries and Aquatic Science 61:1256-1268.

Ollinger, S. V., J. D. Aber, G. M. Lovett, S. E. Milham, and R. G. Lathrop. 1993. A spatial model of atmospheric deposition for the northeastern U.S. Ecological Applications 3:459-472.

Ouimet, R., P. A. Arp, S. A. Watmough, J. Aherne, and I. Demerchant. 2006. Determination and mapping critical loads of acidity and exceedances for upland forest soils in eastern Canada. Water, Air and Soil Pollution 172:57-66.

Pardo, L. H. 2010. Approaches for estimating critical loads of $\mathrm{N}$ and $\mathrm{S}$ deposition for forest ecosystems on U.S. federal lands. General Technical Report NRS-71. USDA Forest Service, Northern Research Station, Newtown Square, Pennsylvania, USA.

Pardo, L. H., et al. 2011a. Synthesis. Pages 229-284 in L. H. Pardo, M. J. Robin-Abbott, and C. T. Driscoll, editors. Assessment of nitrogen deposition effects and empirical critical loads of nitrogen for ecoregions of the United States. General Technical Report NRS-80. USDA Forest Service, Northern Research Station, Newtown Square, Pennsylvania, USA.

Pardo, L. H., E. A. Lilleskov, L. H. Geiser, and M. J. RobinAbbott. 2011b. Methods. Pages 25-35 in L. H. Pardo, M. J. Robin-Abbott, and C. T. Driscoll, editors. Assessment of nitrogen deposition effects and empirical critical loads of nitrogen for ecoregions of the United States. General Technical Report NRS-80. USDA Forest Service, Northern Research Station, Newtown Square, Pennsylvania, USA.

Pardo, L. H., M. J. Robin-Abbott, and C. T. Driscoll. $2011 c$. Assessment of nitrogen deposition effects and empirical critical loads of nitrogen for ecoregions of the United States. General Technical Report NRS-80. USDA Forest Service,
Northern Research Station, Newtown Square, Pennsylvania, USA.

Poikolainen, J., H. Lippo, M. Hongisto, E. Kubin, K. Mikkola, and M. Lindgren. 1998. On the abundance of epiphytic green algae in relation to the nitrogen concentrations of biomonitors and nitrogen deposition in Finland. Environmental Pollution 102:85-92.

Porter, E., T. Blett, D. Potter, and C. Huber. 2005. Protecting resources on federal lands: Implications of critical loads for atmospheric deposition of nitrogen and sulfur. BioScience 55:603-612.

Porter, M. K. 2007. Regional modeling of nitrogen, sulfur, and mercury atmospheric deposition in the Pacific Northwest. M.S. thesis, Washington State University, Pullman, Washington, USA.

Posch, M., P. A. M. de Smet, J.-P. Hettelingh, and R. J. Downing, editors. 1995. Calculation and mapping of critical thresholds in Europe. Status Report 1995. RIVM Report Number 259101004. Coordination Center for Effects, National Institute for Public Health and the Environment, Bilthoven, The Netherlands. 〈http://www. mnp.nl/cce/publ/>

Posch, M., P. A. M. de Smet, J.-P. Hettelingh, and R. J. Downing, editors. 2001. Modelling and mapping of critical thresholds in Europe. Status report 2001. RIVM Report Noumber 259101010. Coordination Center for Effects, National Institute for Public Health and the Environment, Bilthoven, The Netherlands. 〈http://www.mnp.nl/cce/publ/>

Pypker, T. G. 2004. Influence of canopy structure and epiphytes on the hydrology of Douglas-fir forests. Dissertation. Oregon State University, Corvallis, Oregon, USA.

Rabalais, N. N. 2002. Nitrogen in aquatic systems. Ambio 31:102-112.

Rao, L. E., and E. B. Allen. 2010. Combined effects of precipitation and nitrogen deposition on native and invasive winter annual production in California deserts. Oecologia 62:1035-1046.

Rao, L. E., E. B. Allen, and T. Meixner. 2010. Risk-based determination of critical nitrogen deposition loads for fire spread in southern California deserts. Ecological Applications 20:1320-1335.

Rochefort, L., D. H. Vitt, and S. E. Bayley. 1990. Growth, production, and decomposition dynamics of Sphagnum under natural and experimentally acidified conditions. Ecology 71:1986-2000.

Rueth, H. M., and J. S. Baron. 2002. Differences in Englemann spruce forest biogeochemistry east and west of the Continental Divide in Colorado, USA. Ecosystems 5:45-57.

Rueth, H. M., J. S. Baron, and E. J. Allstott. 2003. Responses of Engelmann spruce forests to nitrogen fertilization in the Colorado Rocky Mountains. Ecological Applications 13:664-673.

Saros, J. E., T. J. Michel, S. J. Interlandi, and A. P. Wolfe. 2005. Resource requirements of Asterionella formosa and Fragilaria crotonensis in oligotrophic alpine lakes: implications for recent phytoplankton community reorganizations. Canadian Journal of Fisheries and Aquatic Science 62:16811689.

Schaberg, P. G., D. H. DeHayes, G. J. Hawley, P. F. Murakami, G. R. Strimbeck, and S. G. McNulty. 2002. Effects of chronic $\mathrm{N}$ fertilization on foliar membranes, cold tolerance, and carbon storage in montane red spruce. Canadian Journal of Forest Research 32:1351-1359.

Sickman, J. O., J. M. Melack, and J. L. Stoddard. 2002. Regional analysis of inorganic nitrogen yield and retention in high-elevation ecosystems of the Sierra Nevada and Rocky Mountains. Biogeochemistry 57:341-374.

Slootweg, J., M. Posch, and J.-P. Hettelingh, editors. 2007. Critical loads of nitrogen and dynamic modelling: CCE Progress Report 2007. MNP Report 500090001. Coordination Centre for Effects, National Institute for Public Health and the Environment (RIVM), Bilthoven, The Netherlands. 
Stevens, C. J., N. B. Dise, J. O. Mountford, and D. J. Gowing. 2004. Impact of nitrogen deposition on the species richness of grasslands. Science 303:1876-1879.

Strengbom, J., M. Walheim, T. Näsholm, and L. Ericson. 2003. Regional differences in the occurrence of understory species reflect nitrogen deposition in Swedish forests. Ambio 32:9197.

Suding, K. N., K. L. Gross, and G. R. Houseman. 2004. Alternative states and positive feedbacks in restoration ecology. Trends in Ecology and Evolution 19:46-53.

Sullivan, T. J., B. J. Cosby, K. A. Tonnessen, and D. W. Clow. 2005. Surface water acidification responses and critical loads of sulfur and nitrogen deposition in Loch Vale watershed, Colorado. Water Resources Research 41:W01021.

Sutton, M., S. Reis, and S. M. H. Baker, editors. 2009. Atmospheric ammonia. Springer Science, Dordrecht, the Netherlands.

Thomas, R. Q., C. D. Canham, K. C. Weathers, and C. L. Goodale. 2010. Increased tree carbon storage in response to nitrogen deposition in the US. Nature Geoscience 3:13-17.

Tilman, D. 1987. Secondary succession and the pattern of plant dominance along experimental nitrogen gradients. Ecological Monographs 57:189-214.

Tilman, D. 1993. Species richness of experimental productivity gradients: How important is colonization limitation. Ecology 74:2179-2191.

Tonnesen, G., Z. Wang, M. Omary, and C. J. Chien. 2007. Assessment of nitrogen deposition: modeling and habitat assessment. CEC-500-2005-032. California Energy Commission, PIER Energy-Related Environmental Research, University of California, Riverside, California, USA. 〈http:// www.energy.ca.gov/2006publications/CEC-500-2006-032/ CEC-500-2006-032.PDF $\rangle$

UBA [UmweltBundesAmt]. 2004. Manual on methodologies and criteria for mapping critical levels/loads and geographical areas where they are exceeded. Federal Environmental Agency (UmweltBundesAmt), Berlin, Germany. 〈http:// www.rivm.nl/en/themasites/icpmm/manual-and-downloads/ manual-english/index.html $\rangle$

USDA Forest Service. 2001. U.S. forest facts and historical trends. Report Number FS-696. USDA Forest Service, Washington, D.C., USA.

USDA, NRCS [U.S. Department of Agriculture, Natural Resources Conservation Service]. 2009. The PLANTS database. National Plant Data Center, Baton Rouge, Louisiana, USA. 〈http://plants.usda.gov〉

USDI, FWS [U.S. Department of the Interior, Fish and Wildlife Service]. 2005. Status and trends of wetlands in the conterminous United States 1998 to 2004. U.S. Department of Interior, Fish and Wildlife Service, Washington, D.C., USA.

U.S. EPA [Environmental Protection Agency]. 1993. Air quality criteria for oxides of nitrogen. Volume 2. Report Number EPA/600/8-91/049aF-cF. Office of Health and Environmental Assessment, Environmental Criteria and Assessment Office, Research Triangle Park, North Carolina, USA.

U.S. EPA [Environmental Protection Agency]. 2007. Acid rain and related programs: 2007 Progress Report. U.S. EPA, Washington, D.C., USA. 〈http://www.epa.gov/airmarkets/ progress/docs/2007ARPReport.pdf $\rangle$

U.S. EPA (Environmental Protection Agency). 2008. Integrated Science Assessment (ISA) for oxides of nitrogen and sulfur ecological criteria (final report). Number EPA/600/R-08/ 082F. U.S. Environmental Protection Agency, National Center for Environmental Assessment-RTP Division, Office of Research and Development, Research Triangle Park,
North Carolina, USA. 〈http://cfpub.epa.gov/ncea/cfm/ recordisplay.cfm?deid $=201485\rangle$

van Diepen, L. T. A. 2008. The role and diversity of arbuscular mycorrhizal fungi in Acer saccharum dominated forest ecosystems under natural and $\mathrm{N}$-amended conditions. Dissertation. Michigan Technological University, Houghton, Michigan, USA.

van Diepen, L. T. A., E. A. Lilleskov, K. S. Pregitzer, and R. M. Miller. 2007. Decline of arbuscular mycorrhizal fungi in northern hardwood forests exposed to chronic nitrogen additions. New Phytologist 176:175-183.

Vitt, D. H., K. Wieder, L. A. Halsey, and M. Turetsky. 2003. Response of Sphagnum fuscum to nitrogen deposition: a case study of ombrogenous peatlands in Alberta, Canada. Bryologist 1062:235-245.

Wallander, H. 1995. A new hypothesis to explain allocation of dry matter between mycorrhizal fungi and pine seedlings in relation to nutrient supply. Plant and Soil 169:243-248.

Weathers, K. C., M. L. Cadenasso, and S. T. A. Pickett. 2001. Forest edges as nutrient and pollutant concentrators: Potential synergisms between fragmentation, forest canopies, and the atmosphere. Conservation Biology 15:1506-1514.

Weathers, K., and J. A. Lynch. 2011. Deposition. Pages 15-24 in L. H. Pardo, M. J. Robin-Abbott, and C. T. Driscoll, editors. Assessment of nitrogen deposition effects and empirical critical loads of nitrogen for ecoregions of the United States. General Technical Report NRS-80. USDA Forest Service, Northern Research Station, Newtown Square, Pennsylvania, USA.

Weathers, K. C., S. M. Simkin, G. M. Lovett, and S. E. Lindberg. 2006. Empirical modeling of atmospheric deposition in mountainous landscapes. Ecological Applications 16:1590-1607.

Wedin, D. A., and D. Tilman. 1996. Influence of nitrogen loading and species composition on the carbon balance of grasslands. Science 274:1720-1723.

Weiss, S. B. 1999. Cars, cows, and checkerspot butterflies: Nitrogen deposition and management of nutrient-poor grasslands for a threatened species. Conservation Biology 13:1476-1486.

Whytemare, A. B., R. L. Edmonds, J. D. Aber, and K. Lajtha. 1997. Influence of excess nitrogen deposition on a white spruce (Picea glauca) stand in southern Alaska. Biogeochemistry $38: 173-187$.

Wigand, C., R. A. McKinney, M. A. Charpentier, M. M. Chintala, and G. B. Thursby. 2003. Relationships of nitrogen loadings, residential development, and physical characteristics with plant structure in New England salt marshes. Estuaries 26:1494-1504.

Williams, M. W., and K. A. Tonnessen. 2000. Critical loads for inorganic nitrogen deposition in the Colorado Front Range, USA. Ecological Applications 10:1648-1665.

Wolfe, A. P., J. S. Baron, and R. J. Cornett. 2001. Anthropogenic nitrogen deposition induces rapid ecological changes in alpine lakes of the Colorado Front Range (USA). Journal of Paleolimnology 25:1-7.

Wolfe, A. P., A. C. Van Gorp, and J. S. Baron. 2003. Recent ecological and biogeochemical changes in alpine lakes of Rocky Mountain National Park (Colorado, USA): a response to anthropogenic nitrogen deposition. Geobiology $1: 153-168$.

Wu, W., and C. T. Driscoll. 2010. Impact of climate change on three-dimensional dynamic critical load functions. Environmental Science and Technology 44:720-726.

Yoshida, L. C., and E. B. Allen. $2004 .{ }^{15} \mathrm{~N}$ uptake by mycorrhizal Artemisia californica and the invasive Bromus madritensis of a N-eutrophied shrubland. Biology and Fertility of Soil 39:243-248.

\section{APPENDIX}

Detailed description of methods for estimating empirical critical loads of nitrogen (Ecological Archives A021-137-A1). 